\title{
TOXIC SUBSTANCES FROM COAL COMBUSTION -- A COMPREHENSIVE ASSESSMENT
}

\author{
Quarterly Technical Report
}

Reporting Period: 04/01/1999 - 06/30/1999

Authors: C.L. Senior, T. Panagiotou (1)

G.P. Huffman, N. Yap (2)

JOL Wendt, W. Seames (3)

MR Ames (4)

A.F. Sarofim, J. Lighty (5)

A. Kolker, R. Finkelman, C.A. Palmer S.J. Mroczkowsky (6)

J.J. Helble, R. Mamani-Paco (7)

Report Issue Date: 07/30/1999

DE-AC22-95PC95101--14

(1) Physical Sciences Inc.

20 New England Business Center

Andover, MA 01810-1077

(2) University of Kentucky

Lexington, KY 40506-0059

(3) University of Arizona

Tucson, AZ 85721

(4) Massachusetts Institute of Technology

Cambridge, MA 02139

(5) University of Utah

Salt Lake City, UT 84112

(6) U.S. Geological Survey

Reston, VA 20192

(7) University of Connecticut

Storrs, CT 06269 


\section{TABLE OF CONTENTS}

$\underline{\text { Section }} \quad \underline{\text { Page }}$

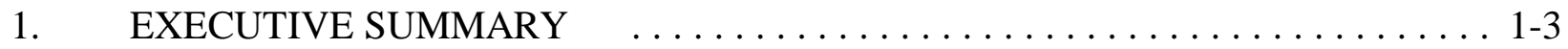

2. INTRODUCTION AND PROGRAM OVERVIEW $\ldots \ldots \ldots \ldots \ldots \ldots \ldots \ldots$

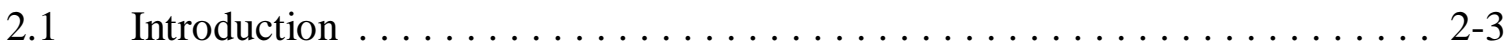

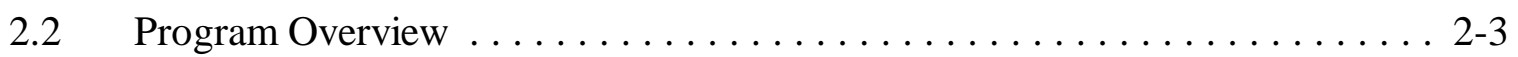

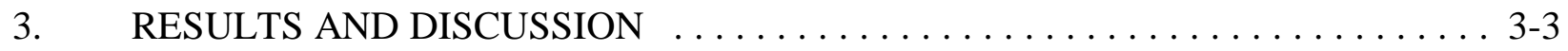

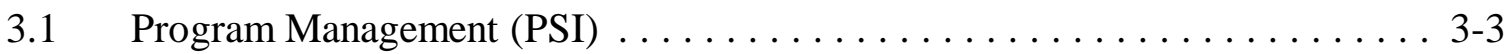

3.2 Coal Characterization (UK, USGS, MIT) $\ldots \ldots \ldots \ldots \ldots \ldots \ldots \ldots \ldots \ldots$

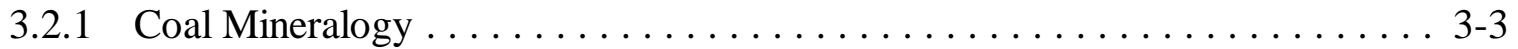

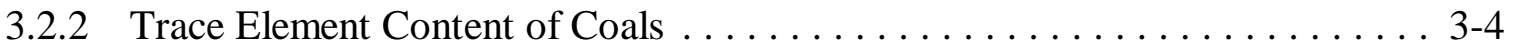

3.2.3 Modes of Occurrence by Microprobe and Leaching Analyses . . . . . . . . . 3-4

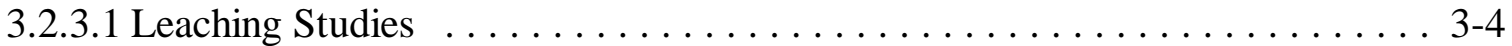

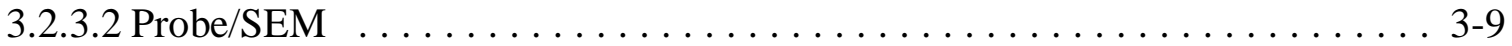

3.2.3.3 Development of a New Procedure for $\mathrm{Hg} \ldots \ldots \ldots \ldots \ldots \ldots \ldots$. . . . . . . . . . . . . . . . . . . . .

3.3 Combustion Zone Transformations (UU, MIT) . . . . . . . . . . . . . . 3-10

3.3.1 Vaporization of Trace Metals During Combustion . . . . . . . . . . . . . 3-10

3.3.2 Measurement of Gas-Phase Mercury and Other Trace Metals . . . . . . . . . 3-11

3.4 Post-Combustion Transformations (UA, UC, UU) . . . . . . . . . . . . 3-12

3.4.1 Large Scale Integrated Combustion Studies . . . . . . . . . . . . . . . 3-12

3.4.1.1 Baseline Studies of Ohio Coal . . . . . . . . . . . . . . . . . . . 3-12

3.4.1.2 Baseline Studies of Wyodak Coal . . . . . . . . . . . . . . . . 3-27

3.4.1.3 Baseline Studies of Illinois No.6 Coal . . . . . . . . . . . . . . . . . 3-46 . . . . . 3-53

3.4.2 Measurement of Post-Combustion Chlorine Speciation . . . . . . . . . . . . 3-53

3.4.3 Bench-Scale Investigation of Gaseous Mercury Chemistry . . . . . . . . . 3-53

3.4.3.1 Flat Flame Burner System for Mercury Oxidation Experiments . . . . . . . . . 3-53

3.4.3.2 Temperature Distribution in Flat Flame Burner System . . . . . . . . . . . . 3-55

3.4.4 XAFS Study of Mercury in Ash and Sorbents . . . . . . . . . . . . . . . 3-60

4. SUMMARY AND FUTURE PLANS $\ldots \ldots \ldots \ldots \ldots \ldots \ldots \ldots \ldots$

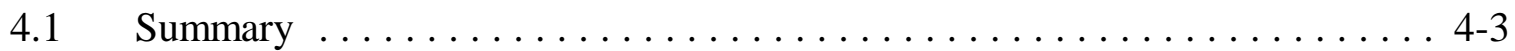

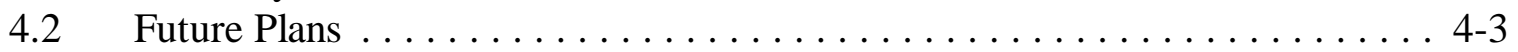


TABLE OF CONTENTS (Continued)

$\underline{\text { Section }}$

$\underline{\text { Page }}$

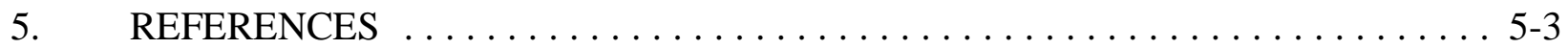

\section{APPENDICES}

A Trace Element Content of Whole Coal Samples on Dry Basis . . . . . . . A A-3

B Revisions to $\mathrm{HNO}_{3}$-Step of USGS Leaching Procedure $\ldots \ldots \ldots \ldots \ldots \ldots$

C Ash Composition from Baseline Combustion Experiments at the University of Arizona for Ohio Coal $\ldots \ldots \ldots \ldots \ldots \ldots$ C-3

D Ash Composition from Baseline Combustion Experiments at the University of Arizona for Wyodak Coal $\ldots \ldots \ldots \ldots \ldots \ldots$ D-3

E Ash Composition from Baseline Combustion Experiments at the University of Arizona for Illinois No.6 Coal . . . . . . . . . . . E-3 


\section{LIST OF FIGURES}

Figure No.

$\underline{\text { Page }}$

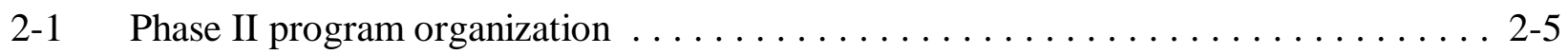

3-1 Typical arsenic distribution in Ohio baseline fly ash at various residence times . . . . 3-13

3-2 Typical selenium distribution in Ohio baseline fly ash at various residence times . . . 3-14

3-3 Typical cadmium distribution in Ohio baseline fly ash at various residence times . . . 3-14

3-4 Typical cobalt distribution in Ohio baseline fly ash at various residence times . . . . 3-15

3-5 Typical antimony distribution in Ohio baseline fly ash at various residence times . . . 3-15

3-6 Typical chromium distribution in Ohio baseline fly ash at various residence times . . 3-16

3-7 Typical cesium distribution in Ohio baseline fly ash at various residence times . . . 3-16

3-8 Arsenic differential enrichment factor comparison, $\left(\mathrm{E}_{\mathrm{f}, 2.2}-\mathrm{E}_{\mathrm{f}, 0.5}\right) \ldots \ldots \ldots \ldots$

3-9 Selenium differential enrichment factor comparison, $\left(\mathrm{E}_{\mathrm{f}, 2.2}-\mathrm{E}_{\mathrm{f}, 0.5}\right) \ldots \ldots \ldots .20$

3-10 Cesium differential enrichment factor comparison, $\left(\mathrm{E}_{\mathrm{f}, 2.2}-\mathrm{E}_{\mathrm{f}, 0.5}\right) \ldots \ldots \ldots \ldots .21$

3-11 Particle size dependence of As, $\mathrm{Se}, \mathrm{Cd}, \mathrm{Co}, \mathrm{Sb}, \mathrm{Cr}$, and $\mathrm{Cs}$ from combustion of Ohio $5 / 6 / 7$ Blend coal sampled at 2.2 seconds . . . . . . . . . 3-23

3-12 Arsenic-calcium correlation for Ohio Blend fly ash at various residence times . . . . 3-23

3-13 Selenium-calcium correlation for a) Ohio Blend at 0.5 seconds, and

b) Ohio Blend at 2.2 seconds and hot-side ESP conditions . . . . . . . . . 3-24

3-14 Cadmium-calcium correlation for Ohio Blend coal at various residence times . . . . 3-25

3-15 Cobalt-calcium correlation for Ohio Blend coal at various residence times . . . . . 3-25

3-16 Antimony-calcium correlation for a) Ohio Blend at 0.5 seconds and hot-side ESP conditions and b) Ohio Blend at 2.2 seconds . . . . . . . . 3-26

3-17 Cesium-calcium correlation for Ohio Blend fly ash at various

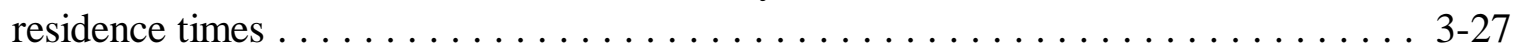




\section{LIST OF FIGURES (Continued)}

Figure No.

$\underline{\text { Page }}$

3-18 Arsenic-aluminum correlation for Ohio Blend fly ash . . . . . . . . . . . 3-28

3-19 Selenium-aluminum correlation for Ohio Blend fly ash . . . . . . . . . . . . . 3-29

3-20 Cesium-aluminum correlation for Ohio Blend fly ash $\ldots \ldots \ldots \ldots \ldots$. . . . . . . .

3-21 Typical self-evolving temperature profile for Wyodak coal combustion in the University of Arizona downflow combustor $\ldots \ldots \ldots \ldots \ldots \ldots \ldots \ldots$

3-22 Typical particle size distributions for Wyodak fly ash $\ldots \ldots \ldots \ldots \ldots \ldots$ 3-33

3-23 Particle size distribution data at 1.4 seconds for Wyodak fly ash . . . . . . . . . . 3-34

3-24 Particle size distribution data at 6.6 seconds for Wyodak fly ash . . . . . . . . . 3-34

3-25 Particle size distribution data at hot-side ESP conditions for Wyodak fly ash . . . . 3-35

3-26 Typical arsenic distribution in Wyodak baseline fly ash at various residence times . . . . . . . . . . . . . . . . . . . . . 36

3-27 Typical selenium distribution in Wyodak baseline fly ash at various residence times . . . . . . . . . . . . . . . . . . . . . . . . . .

3-28 Typical cadmium distribution in Wyodak baseline fly ash at various

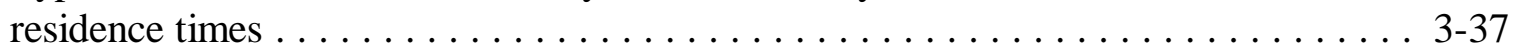

3-29 Typical cobalt distribution in Wyodak baseline fly ash at various

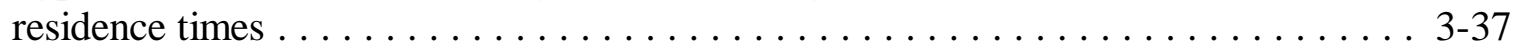

3-30 Typical antimony distribution in Wyodak baseline fly ash at various

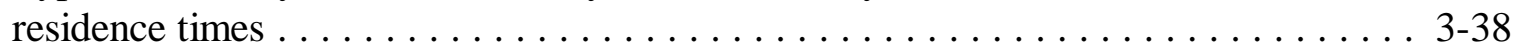

3-31 Typical chromium distribution in Wyodak baseline fly ash at various residence times . . . . . . . . . . . . . . . . . . $\ldots \ldots \ldots$

3-32 Arsenic differential enrichment factor comparison $\ldots \ldots \ldots \ldots \ldots \ldots \ldots \ldots$. . . . . .

3-33 Selenium differential enrichment factor comparison $\ldots \ldots \ldots \ldots \ldots \ldots \ldots \ldots$ 3-41

3-34 Cobalt differential enrichment factor comparison $\ldots \ldots \ldots \ldots \ldots \ldots \ldots$. . . . . 3-42 


\section{LIST OF FIGURES (Continued)}

Figure No.

$\underline{\text { Page }}$

3-35 Antimony differential enrichment factor comparison . . . . . . . . . . . . 3-42

3-36 Chromium differential enrichment factor comparison $\ldots \ldots \ldots \ldots \ldots \ldots \ldots$. . . . . .

3-37 Particle size dependence of As, $\mathrm{Se}, \mathrm{Cd}, \mathrm{Co}, \mathrm{Sb}$, and $\mathrm{Cr}$ sampled at 6.6 seconds from combustion of Wyodak Coal . . . . . . . . . . . . . 3-44

3-38 Arsenic-calcium correlation for Wyodak fly ash . . . . . . . . . . . . 3-45

3-39 Selenium-calcium correlation for Wyodak fly ash . . . . . . . . . . . . . 3-46

3-40 Cadmium-calcium correlation for Wyodak fly ash . . . . . . . . . . . . . . 3-47

3-41 Cobalt-calcium correlation for Wyodak fly ash . . . . . . . . . . . . . 3-48

3-42 Antimony-calcium correlation for Wyodak fly ash . . . . . . . . . . . . . . . 3-49

3-43 Chromium-calcium correlation for Wyodak fly ash . . . . . . . . . . . 3-50

3-44 Typical particle size distribution for Illinois No. 6 fly ash collected

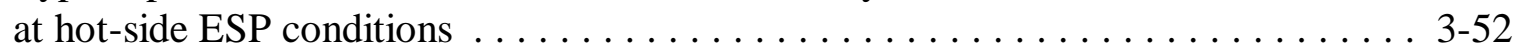

3-45 Typical trace element distributions in Illinois No. 6 fly ash collected

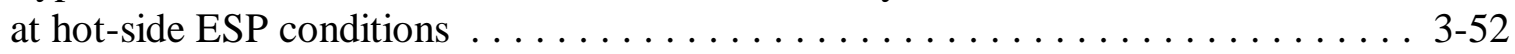

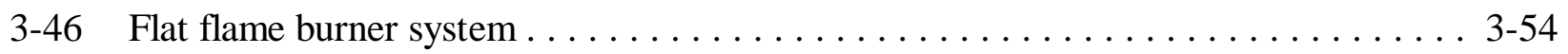

3-47 Temperature profiles at different equivalence ratios, at the top and bottom

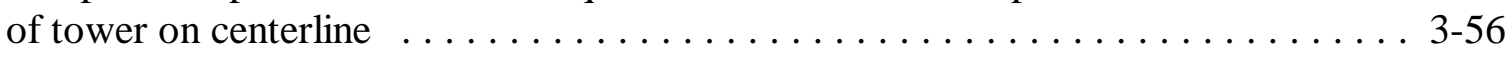

3-48 Temperature profiles at different equivalence ratios, at the top and bottom

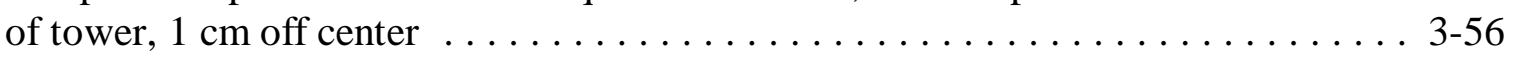

3-49 Temperature profiles at different equivalence ratios, at the top and bottom

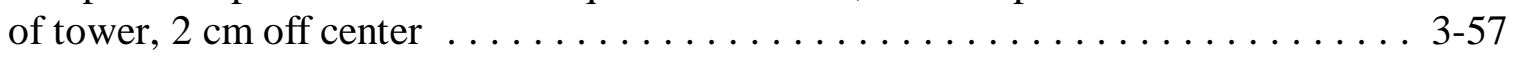

3-50 Temperature profiles at different flow rates, similar equivalence ratios,

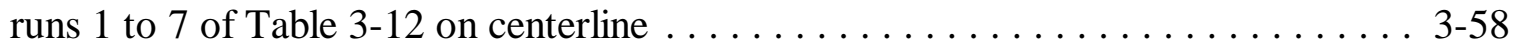




\section{LIST OF FIGURES (Continued)}

Figure No.

$\underline{\text { Page }}$

3-51 Temperature profiles at different flow rates, similar equivalence ratios, runs 1 to 7 of Table $3-12,1 \mathrm{~cm}$ off centerline . . . . . . . . . . . . . . 3-59

3-52 Temperature profiles at different flow rates, similar equivalence ratios, runs 1 to 7 of Table $3-12,2 \mathrm{~cm}$ off centerline . . . . . . . . . . . . . . . 3-59

3-53 Comparison of the spectral simulation trends with data obtained from Hg-impregnated chars obtained from the University of Arizona combustor . . . . . . 3-60

3-54 Correlation between carbon content and mercury content for fractions of ADA baghouse-hopper fly ash separated by triboelectrostatic separation . . . . . 3-61 


\section{LIST OF TABLES}

Table No.

$\underline{\text { Page }}$

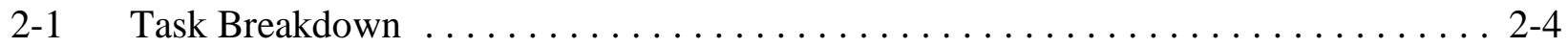

3-1 Trace Element Concentrations in Phase II Coals by Neutron Activation Analysis ... . 3-5

3-2 Trace Element Concentrations in Phase II Coals on As Received Basis, Based on USGS Analysis . . . . . . . . . . . . . . . . . .

3-3 Ash Composition in Terms of Total Oxides . . . . . . . . . . . . . . . 3-9

3-4 Enrichment Factors $\left(\mathrm{E}_{\mathrm{f}}\right)$ for Ohio Fly Ash Sampled at 0.5 Seconds, 2.2 Seconds, and Hot-Side ESP Conditions . . . . . . . . . . . . . . . 3-19

3-5 Summary of the Phase II Wyodak Baseline Test Runs . . . . . . . . . . . . 3-31

3-6 Summary of Experimental Sampling Conditions for Wyodak Baseline Combustion . . . . . . . . . . . . . . . . . . . . . . . 3-32

3-7 Preliminary Enrichment Factors $\left(\mathrm{E}_{\mathrm{f}}\right)$ for Wyodak fly ash sampled at 1.4 Seconds, 6.6 Seconds, and Hot-side ESP Conditions . . . . . . . . . . . . 3-40

3-8 A Summary of the Illinois No. 6 Hot-Side ESP Baseline Test Runs . . . . . . . . 3 3-51

3-9 A Summary of Experimental Sampling Conditions For Illinois No. 6

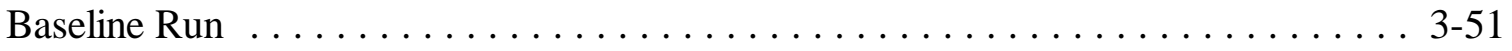

3-10 Flow Conditions at Different Equivalence Ratios . . . . . . . . . . . . 3-56

3-11 Temperature Measurements at the Outlet of Insulated Mixing Chamber . . . . . . . 3-57

3-12 Flow Conditions for Temperature Measurement Experiments . . . . . . . . . . 3-58

3-13 Data for Triboelectrostatic Separation on ADA Cherokee Fly Ash Sample . . . . . . 3-61

3-14 Data for Triboelectrostatic Separation on ADA Cherokee

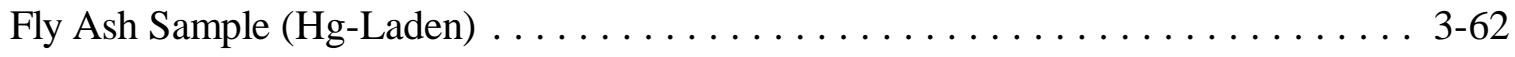

3-15 Data for Triboelectrostatic Separation on ADA Cherokee Fly Ash Sample (Desorbed) . . . . . . . . . . . . . . . . . . . . . 3-63 


\begin{abstract}
The Clean Air Act Amendments of 1990 identify a number of hazardous air pollutants (HAPs) as candidates for regulation. Should regulations be imposed on HAP emissions from coal-fired power plants, a sound understanding of the fundamental principles controlling the formation and partitioning of toxic species during coal combustion will be needed. With support from the Federal Energy Technology Center (FETC), the Electric Power Research Institute, and VTT (Finland), Physical Sciences Inc. (PSI) has teamed with researchers from USGS, MIT, the University of Arizona (UA), the University of Kentucky (UK), the University of Connecticut (UC), the University of Utah (UU) and the University of North Dakota Energy and Environmental Research Center (EERC) to develop a broadly applicable emissions model useful to regulators and utility planners. The new Toxics Partitioning Engineering Model (ToPEM) will be applicable to all combustion conditions including new fuels and coal blends, low- $\mathrm{NO}_{\mathrm{x}}$ combustion systems, and new power generation plants. Development of ToPEM will be based on PSI's existing Engineering Model for Ash Formation (EMAF).
\end{abstract}

This report covers the period from 1 April 1999 to 30 June 1999. During this quarter low temperature ashing and elemental analysis of the three Phase II coals were completed. Results from MIT and USGS are comparable. Plans were made for measurements of loss of trace elements during devolatilization and for single particle combustion studies at the University of Utah. The iodated charcoal trap was tested on coal combustion flue gas and was shown to collect both $\mathrm{Hg}$ and $\mathrm{Se}$ in from the vapor phase with $100 \%$ efficiency. Data from the University of Arizona self-sustained combustor were analyzed from the combustion of three coals: Ohio, Wyodak and Illinois No. 6. Ash size distributions and enrichment factors for selected trace elements were calculated. The correlation between the concentration of the more volatile trace elements in the ash and the concentration of major elements such as calcium and aluminum was also examined. Work continued at the University of Utah toward the measurement of chlorine speciation in flue gas. The flat flame burner system for the study of mercury chemistry is nearly complete at the University of Connecticut. XAFS analysis by the University of Kentucky indicated that vapor phase $\mathrm{HgCl}_{2}$ was adsorbed by char samples as $\mathrm{HgCl}_{2}$ (i.e., physisorption), whereas vapor phase $\mathrm{Hg}_{0}$ must react (chemisorption) with species on the char surface to form a chemical complex. Hg-laden and desorbed fly-ash samples obtained from a power plant were separated into carbon-rich and carbon-poor fractions by triboelectrostatic separation. 


\section{SECTION 1}

EXECUTIVE SUMMARY

$1-1 / 1-2$ 


\section{EXECUTIVE SUMMARY}

The technical objectives of this project are:

a) To identify the effect of the mode-of-occurrence of toxic elements in coal on the partitioning of these elements among vapor, submicron fume, and fly ash during the combustion of pulverized coal,

b) To identify the mechanisms governing the post-vaporization interaction of toxic elements and major minerals or unburnt char,

c) To determine the effect of combustion environment (i.e., fuel rich or fuel lean) on the partitioning of trace elements among vapor, submicron fume, and fly ash during the combustion of pulverized coal,

d) To model the partitioning of toxic elements among various chemical species in the vapor phase and between the vapor phase and complex aluminosilicate melts,

e) To develop the new Toxics Partitioning Engineering Model (ToPEM), applicable to all combustion conditions including new fuels and coal blends, low- $\mathrm{NO}_{\mathrm{x}}$ combustion systems, and new power generation plants.

A description of the work plan for accomplishing these objectives is presented in Section 2.1 of this report.

The work discussed in this report covers the period from 1 April 1999 to 30 June 1999. During this quarter low temperature ashing and elemental analysis of the three Phase II coals were completed. Results from MIT and USGS are comparable. A recurring problem with incomplete pyrite digestion in the $\mathrm{HNO}_{3}$ leaching step has been resolved, but necessitates another complete round of leaching of project samples. In the meantime, USGS personnel are moving forward with XRD mineralogy, ion probe work, and other determinations, and continue to investigate an improved (versus CVAA) method of $\mathrm{Hg}$ determination.

A meeting including personnel from MIT and Utah was held to discuss the neutron activation analysis (NAA) results from the initial experiments on loss of trace elements during devolatilization. A plan for another round of testing has been developed. Experiments will be conducted on three coals: Ohio (5/6/7), Wyodak, and North Dakota lignite. These will be burned at $1650 \mathrm{~K}$ with a series of oxygen concentrations: $0 \%, 20 \%, 50 \%$, and $100 \%$ oxygen. The balance of the gas will be either nitrogen or carbon dioxide.

The iodated charcoal used for vapor phase $\mathrm{Hg}$ collection was tested to see whether it collected other vapor phase metals. The tests were performed at PSI using the entrained flow reactor (EFR). The Pittsburgh coal from Phase I was burned at $1500^{\circ} \mathrm{C}$ at a stoichiometric ratio of 1.2. As expected, the charcoal in the front sorbent collected $100 \%$ of the vapor phase $\mathrm{Hg}$, and 
the amount of $\mathrm{Hg}$ collected increased linearly with the test duration. The other element which was collected with $100 \%$ efficiency by the front sorbent was Se.

Data from the University of Arizona self-sustained combustor were analyzed from the combustion of three coals: Ohio, Wyodak and Illinois No. 6 (the latter from Phase I). Ash size distributions and enrichment factors for selected trace elements were calculated. The correlation between the concentration of the more volatile trace elements in the ash and the concentration of major elements such as calcium and aluminum was also examined.

For the Ohio coal, there is evidence for heterogeneous condensation of arsenic vapors on the supermicron ash particles in the post combustion zone as the gas cools from approximately $1350 \mathrm{~K}$ to $1100 \mathrm{~K}$. Selenium vapor appears to condense on the submicron ash particles over the same temperature range. The arsenic concentration in the Ohio ash particles does not show a correlation with calcium content, as one might expect if arsenic vapors were chemically reacting with calcium in the ash. Selenium, however, does show a correlation with calcium in the temperature range of 1100 to $1350 \mathrm{~K}$. These observations suggest that vapor-phase selenium may be more reactive than vapor-phase arsenic with respect to calcium in fly ash. A correlation between cesium and aluminum concentrations in ash suggests the formation of Cs-Al compounds.

For the Wyodak coal, arsenic, selenium, antimony, and chromium appear to condense preferentially on the submicron ash particles as the gas temperature falls from 1350 to $1100 \mathrm{~K}$. The dependence of concentration of certain trace elements (As, Se, Cd, Co) in the supermicron ash particles on particle diameter suggests that condensation of these elements from the vaporphase is controlled by a chemical reaction (rather than by gas film diffusion). As, Se, and Cd concentrations in the ash are correlated with the calcium concentration suggesting, once again, the formation of calcium compounds.

Work continued at the University of Utah toward the measurement of chlorine speciation in flue gas. EPA Method 26 will be tested for the ability to speciate chlorine $\left(\mathrm{HCl}\right.$ versus $\left.\mathrm{Cl}_{2}\right)$ in the presence of $\mathrm{SO}_{2}$. If $\mathrm{SO}_{2}$ does cause bias in the measurement, as indicated in the literature, an alternate measurement method will be used to measure $\mathrm{Cl}_{2}$ in parallel with Method 26 .

The University of Connecticut has nearly completed construction of the bench-scale apparatus for examination of the chemistry of mercury in the gas-phase. Preliminary measurements of temperatures in the post-flame region were made.

During the last quarter, the major focus at the University of Kentucky was to complete an examination of possible trends in XAFS parameters that might reflect $\mathrm{Hg}$ sorption involving mixtures of $\mathrm{Hg}$ and $\mathrm{HgCl}_{2}$ species on carbon-based sorbents. For the University of Arizona char sorbents made from project coals, it would appear that vapor phase $\mathrm{HgCl}_{2}$ is sorbed as $\mathrm{HgCl}_{2}$ (i.e., physisorption), whereas vapor phase $\mathrm{Hg}^{0}$ must react (chemisorption) with species on the char surface to form a chemical complex. Hg-laden and desorbed fly-ash samples obtained from the Cherokee, $\mathrm{CO}$, power plant from collaborators at ADA Technologies have been separated into carbon-rich and carbon-poor fractions by triboelectrostatic separation. 


\section{SECTION 2}

INTRODUCTION AND PROGRAM OVERVIEW 


\section{INTRODUCTION AND PROGRAM OVERVIEW}

\section{$2.1 \quad$ Introduction}

Before electric utilities can plan or implement emissions minimization strategies for hazardous pollutants, they must have an accurate and site-specific means of predicting emissions in all effluent streams for the broad range of fuels and operating conditions commonly utilized. Development of a broadly applicable emissions model useful to utility planners first requires a sound understanding of the fundamental principles controlling the formation and partitioning of toxic species during coal combustion. PSI and its team members will achieve this objective through the development of an "Engineering Model" that accurately predicts the formation and partitioning of toxic species as a result of coal combustion. The "Toxics Partitioning Engineering Model" (ToPEM) will be applicable to all conditions including new fuels or blends, low- $\mathrm{NO}_{\mathrm{x}}$ combustion systems, and new power systems being advanced by DOE in the Combustion 2000 program.

Based on a goal of developing and delivering this ToPEM model, a 5-year research program was proposed. This program is divided into a 2-year Phase I program and a 3-year Phase II program. The objective of the ongoing Phase II program is to develop an experimental and conceptual framework for the behavior of selected trace elements (arsenic, selenium, chromium, and mercury) in combustion systems and incorporate these concepts into a new engineering model. This Phase II objective will be achieved by a team of researchers from USGS, the Massachusetts Institute of Technology (MIT), the University of Arizona (UA), the University of Kentucky (UK), the University of Connecticut (UC), the University of Utah (UU), the University of North Dakota Energy \& Environmental Research Center (EERC) and PSI. Model development and commercialization will be carried out by PSI.

\section{2 $\quad$ Program Overview}

Our general approach to the development of the ToPEM model is to break the process for toxic formation into sub-processes, each of which will be addressed by team members who are experts in the area. Ultimately, this will result in new sub-models which will be added to the existing Engineering Model for Ash Formation (EMAF) to create ToPEM. Table 2-1 describes the work breakdown structure for the Phase II program. Figure 2-1 illustrates the relationship between the elements of the Phase I work breakdown structure and the subprocesses. Each of the areas identified in the figure will be addressed in the Phase II program as described below.

\section{Forms of Occurrence of Trace Elements in Coal}

One of the most important questions to be answered in the program as a whole is whether the form of a particular element in the coal affects its form of emission at the end of the process. The answer to this question will determine the shape of the sub-models that must be developed in this program. Thus, a detailed understanding of the forms of individual trace elements in coal 
Table 2-1. Task Breakdown

\begin{tabular}{|l|c|c|}
\hline \multicolumn{1}{|c|}{ Technical Task } & $\begin{array}{c}\text { Team } \\
\text { Member }\end{array}$ & $\begin{array}{c}\text { Task (WBS) } \\
\text { Number }\end{array}$ \\
\hline \hline Program management & PSI & 1 \\
\hline Coal acquisition, characterization & PSI & 2 \\
\hline Coal, ash trace element characterization & PSI & 2 \\
\hline $\begin{array}{l}\text { Coal (and ash) characterization -- forms of } \\
\text { occurrence }\end{array}$ & UK, USGS & 3,4 \\
\hline $\begin{array}{l}\text { Coal, ash trace element characterization and } \\
\text { mercury capture and analysis }\end{array}$ & MIT & 5.2 \\
\hline $\begin{array}{l}\text { Mechanistic study: dilute bench scale combustion } \\
\text { tests plus equilibrium, kinetic modeling }\end{array}$ & UU & 5.1 \\
\hline Large scale tests at 100,000 Btu/h facility & UA & 6 \\
\hline $\begin{array}{l}\text { Mechanistic study of kinetic rates for gas-phase } \\
\text { reactions }\end{array}$ & UC & 10 \\
\hline Mercury-fly ash interactions at bench scale & EERC & 11 \\
\hline Fundamental Engineering Model development & PSI & 9.1 \\
\hline $\begin{array}{l}\text { Inorganic emissions: literature survey and model } \\
\text { validation }\end{array}$ & UC & 9.2 \\
\hline
\end{tabular}

provides a foundation for much of the rest of the program. Key issues that will be addressed in Phase II are the specific mineral associations of individual elements and the relationship between trace metal form and "standard" coal analyses.

Because of the importance of elemental form (e.g., sulfate versus silicate mineral) on partitioning, it is critical that coals representing a broad range of elemental forms be examined in this program. In Task 2 we will select and acquire a total of three coals for study in this program. The coals chosen will represent a broad range of elemental forms of occurrence taken from the major coal ranks and commercial coal seams used for pulverized coal power generation in the US. Once selected, fresh coal samples will be acquired and distributed to team members. These samples will be subjected to ultimate, proximate, and ASTM ash analysis. Coal samples will be analyzed for trace element concentrations by Neutron Activation Analysis (NAA) at the MIT Nuclear Reactor Laboratory (Task 5.2).

Advanced analytical techniques such as Mössbauer spectroscopy and ComputerControlled Scanning Electron Microscopy (CCSEM) will be used by UK (Task 3) to determine the major mineral species present in the program coals and the combustion generated ash. Whole coal samples and density segregated coal samples will be studied. This analysis will provide important insight on the minerals present in the coal, how they interact during the combustion process, and how this interaction may affect the partitioning of toxic elements. 


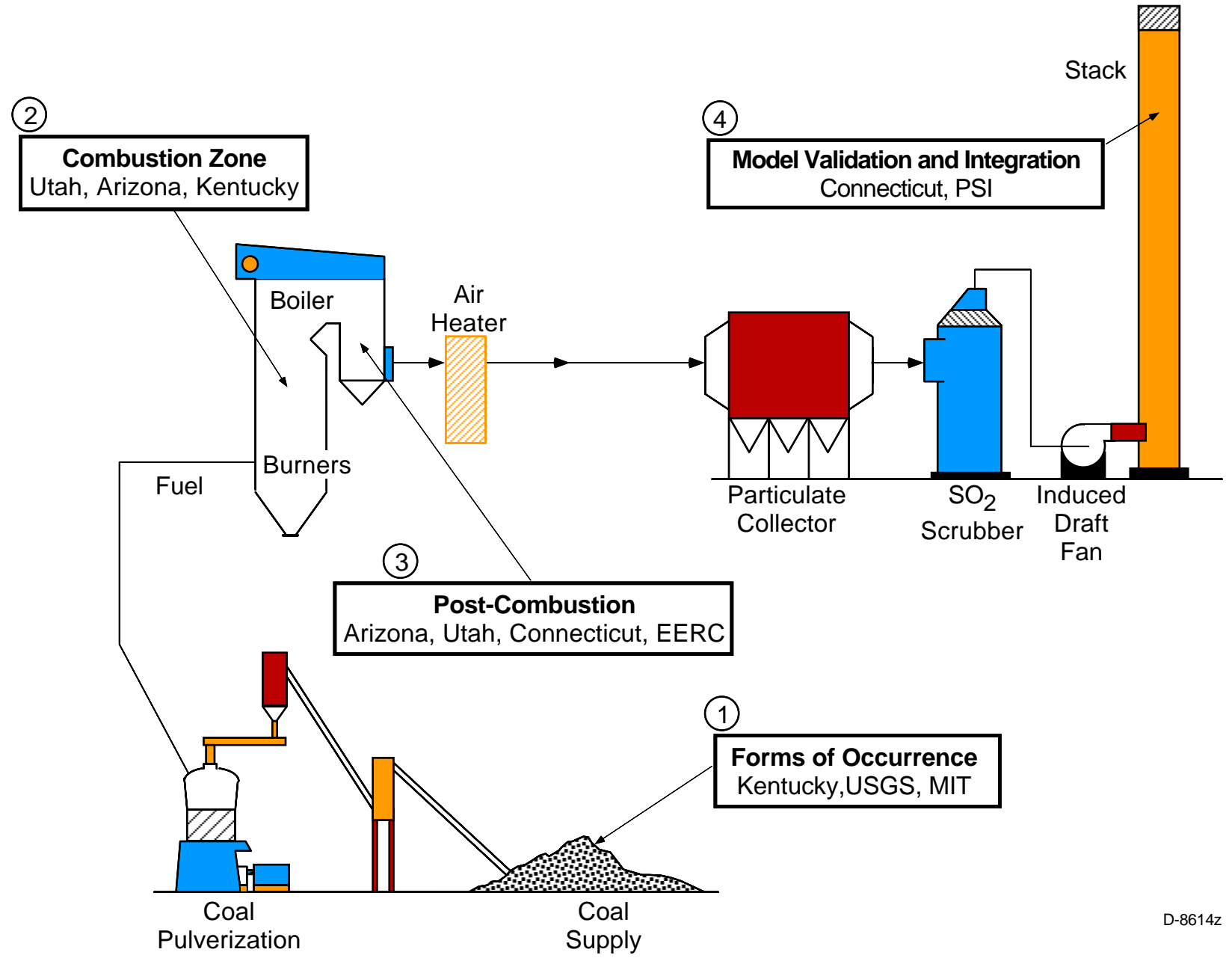

Figure 2-1. Phase II program organization.

Another important issue is the form-of-occurrence of the trace elements in the coal. In this task the mode of occurrence of As, $\mathrm{Cr}$, and Se will be determined by combining XAFS and the Mössbauer/CCSEM derived data discussed above. $\mathrm{Hg}$ will also be evaluated where possible. Other less critical trace elements ( $\mathrm{Mn}, \mathrm{Ni}, \mathrm{Zn}, \mathrm{Pb}, \mathrm{U}$, etc.) may also be evaluated, especially if their abundance is unusually high in any of the program coals. In addition, the form-ofoccurrence of $\mathrm{Cl}$ and $\mathrm{S}$ in coals and chars will be investigated.

As a complement to the XAFS analysis mentioned above, a unique protocol developed by USGS will be used in Task 4 to analyze selected raw coal, and size and density segregated coal, samples for trace element forms of occurrence. This protocol combines low temperature (<200EC) ashing, chemical analysis, x-ray diffraction, coal segregation via flotation, ammonium acetate and selected acid leaching, electron microbeam measurements, and low and moderate temperature heating tests to determine the forms of elements in coal. Because of the unique combination of existing testing and analytical facilities available at USGS, the work will be conducted at USGS laboratories. 


\section{Combustion Zone Transformations}

The effect of coal type and combustion conditions on the emission of the toxic trace elements will be investigated using the UU laminar-flow drop tube reactor (Task 5.1). The fundamental mechanisms of toxic species formation and partitioning will be determined from careful examination of the ash formed under a variety of combustion conditions. Measurements will be made of the partitioning of the trace elements in the three coals as a function of temperature and equivalence ratio. These measurements will provide the baseline data on the fraction vaporized. Individual size-segregated ash samples (collected with a cascade impactor) will then be analyzed by NAA for total composition and other analyses as needed, for example, Auger and STEM for surface composition, TEM and SEM for particle morphology, and possibly water washing and/or chemical leaching to determine the solubility of selected trace elements in the ash samples. Samples will also be submitted to UK for chemical species analysis by XAFS and other techniques.

\section{Post-Combustion Transformations}

The goal of this task is an increased understanding of the transformations of selected metals as the flue gases cool following the high temperature combustion zone. Bench scale experimentation will be carried out by several organizations as well as large scale combustion measurements. Advanced analytical methods will be used extensively to understand speciation of trace elements in the post-combustion flue gas.

At the UC (Task 10) experiments will focus on determination of trace vapor-ash particle reactions rates in post-combustion gases, including

- Identification of the rate controlling phenomena in the oxidation of arsenic under combustion conditions

- $\quad$ Relative rates of gas-phase reaction of elemental mercury with $\mathrm{HCl}$ and $\mathrm{Cl}_{2}$ under combustion conditions

- Measurement of rates of heterogeneous conversion of $\mathrm{HCl}$ to $\mathrm{Cl}_{2}$ in the presence of coal combustion products such as iron oxide, iron sulfate, and fly ash samples.

Interactions of mercury with ash and ash components at lower temperatures will be the focus of the effort at EERC in Task 11. A bench-scale sorbent evaluation system will be used to increase our understanding of the interactions between gas-phase mercury and coal ash. Experiments will explore the effects of temperature and the interactions between elemental mercury or mercuric chloride and fly ash samples generated under oxidizing conditions, the effect of mercury concentration on the interactions between elemental mercury and fly ash, and the effect of coal combustion conditions on the ash and ultimately on the interaction between mercury and ash. 
On a larger scale in Task 6, UA will determine how both coal composition, detailed mineralogy and combustion conditions (including low $\mathrm{NO}_{\mathrm{x}}$ conditions) govern the fate of toxic metals under practical time/temperature, self sustained, yet still aerodynamically well defined, pulverized coal combustion conditions. Program coals will be burned in the UA self-sustained combustor under premixed conditions. The baseline tests will employ the naturally occurring temperature profile for each coal at a stoichiometric ratio of 1.2. Samples will be withdrawn at several ports, representing a range of temperatures and residence times. Complete impactor samples will be collected and analyzed for each toxic metal (11 as listed in the CAAA plus U and Th) plus major elements. This will yield the particle size segregated toxic metal composition, which can be compared to data obtained from other tasks of this program. These data will then be examined to determine particle size dependence in order to infer possible mechanisms governing the fate of each metal.

\section{Model Validation}

UC will conduct a more in-depth review of the relevant field data on inorganic emissions (Task 9.2). In Phase II we will emphasize use the field data to validate the models we will develop. The Phase II effort focuses on data from the following sources:
- $\quad$ EPRI PISCES
- DOE Program
- $\quad$ VTT (Finland)
- $\quad$ KEMA (Netherlands).

Important issues to be addressed when reviewing these data include mass balance closure, methods of analysis and sample collection, effect of APCD, effect of bulk coal ash chemistry, particle size distribution, and speciation of $\mathrm{Hg}$.

\section{Model Development}

In Task 9.1, data obtained from subcontractor and PSI tasks will be combined to create a comprehensive model of the transformations of important inorganic species during combustion. This model, denoted the ToPEM, will be based on an existing model (the PSI Engineering Model for Ash Formation which predicts ash particle size and composition distributions - EMAF). Because the development of this model is strongly dependent on the mechanistic, equilibrium, and kinetic information being developed under the experimental tasks, ToPEM will incorporate information on the mechanisms controlling species behavior, equilibrium modeling where appropriate and kinetic modeling to mimic kinetic constraints on species behavior. During the later stages of the Phase II work, sufficient detailed information will be available to support specific modifications to EMAF in order to describe the combustion transformations of important inorganic trace elements. Based on the experimental studies, equilibrium modeling, and kinetic modeling, it will be clear which modifications are required. Once complete, the model will be validated using a combination of laboratory and field data. As part of the validation effort, coal and size fractionated ash samples collected from operating utility boilers will be provided by Dr. Esko Kauppinen of VTT, Finland. Once validated, the ToPEM will be used to simulate the 
behavior of these and other coals under utility boiler conditions. The results from these simulations will then be compared to field data from PISCES obtained through EPRI participation in this program, DOE field sampling campaigns, and other relevant data in the literature. This validation procedure will ensure that the model developed as the result of the proposed research efforts accurately predicts the behavior of toxic metals species from a wide range of coals during the combustion process in any combustion system. 


\section{SECTION 3}

RESULTS AND DISCUSSION

$3-1 / 3-2$ 


\section{RESULTS AND DISCUSSION}

\subsection{Program Management (PSI)}

The next program review meeting has been scheduled for September 30, 1999 at the DOE Federal Energy Technology Center in Pittsburgh. A preliminary agenda was sent to all program participants.

\subsection{Coal Characterization (UK, USGS, MIT)}

The coals in Phase II were chosen in an attempt to (1) represent a broad range of elemental forms of occurrence and (2) represent the major coal ranks and commercial coal seams used for pulverized coal power generation in the U.S. A bituminous coal from Ohio coal was selected for study. The particular coal sample was a blend of three seams: Ohio 5, Ohio 6, and Ohio 7. This blend was made for testing at McDermott Technologies Clean Environment Development Facility (CEDF). The CEDF test program, also sponsored by DOE, is intended to study mercury emissions from coal-fired combustion systems and the interactions of mercury and air pollution control devices such as scrubbers. A similar coal, a blend of Ohio 5 and 6 seams, is burned at a full scale power plant which is currently being sampled for trace element emissions in another DOE-sponsored program.

The second coal in Phase II is a lignite from North Dakota (Hagel Bed). This coal is burned at a mine-mouth utility power plant in North Dakota. While lignites are not major steam producing coals throughout the United States, they are important regionally. The mineralogy of lignites from this seam is different from other coals. A pulverized sample was obtained from EERC. This coal is also burned at a full scale power plant which will be sampled for trace element emissions in another DOE-sponsored program.

The third coal is from the Wyodak seam. This is a sub-bituminous coal from the Powder River Basin and is an important steam coal. The Phase I Wyodak sample was obtained through ABB. Since there was not enough of the Phase I material left for Phase II, a fresh sample was procured from a power plant which burns this coal. Both Phase I and Phase II samples came from the same mine, although the samples were mined approximately two years apart.

\subsubsection{Coal Mineralogy}

Low-temperature ashing by USGS of all Phase II samples is now complete. Because of their low rank, the initial ashing step was repeated for the unleached Wyodak and North Dakota samples following a precursory leaching with ammonium acetate to remove carboxyl-bound cations. These ions tend to neutralize the oxygen plasma in the LTA apparatus, thereby greatly reducing the rate of ash generation. The precursory leaching step also helps prevent fixation of organic sulfur as sulfate, which can obscure the X-ray diffractogram and make it difficult to interpret. All Phase II LTA powders are now ready for semi-quantitative determination of sample mineralogy by X-ray diffraction (XRD). These determinations are commencing. 


\subsubsection{Trace Element Content of Coals}

Calcium analyses by NAA of the three Phase II coals have been performed at the MIT Nuclear Reactor Laboratory. The results for the Ohio and Wyodak coals were consistent among the replicates, but the measured concentrations for the North Dakota coal varied by more than the calculated error, so that coal will be analyzed again. The measured Ca concentrations and 1-sigma errors are given in Table 3-1 together with values for the elements previously measured.

Whole-coal elemental analysis is an important part of characterizing the project samples, and it also forms the basis for comparing leached samples. The USGS uses a combined approach that includes the optimal results of ICP-MS, ICP-AES, and NAA multi-element methods, and element-specific methods for Se (hydride generation) and Hg. A complete data set for each of the Phase II coals (on a dry basis) has been returned (from USGS labs in Denver) and these data are included in Appendix A. These data are a composite of best values to date, and will change only if additional replicates are run. In Table 3-2, the concentrations have been converted to an as received basis, based on the reported moisture content of the coal, in order to allow comparison between the MIT and USGS data. The agreement is generally good. However, the mercury content of the North Dakota lignite does not show good agreement between the two analyses.

The results summarized in Tables 3-1 and 3-2 contain most of the major inorganic elements in the ash. Concentrations of the major elements were also measured by x-ray fluorescence (XRF) using the standard ASTM procedure for ash composition (as reported in the quarterly report covering July 1998 through September 1998). In Table 3-3, the MIT and USGS analyses have been expressed as oxides for the major and minor elements and normalized to an ash-only basis using the ash content of the coal (as received basis). The XRF analysis has been converted to a sulfur-free basis.

\subsubsection{Modes of Occurrence by Microprobe and Leaching Analyses}

\subsubsection{Leaching Studies}

All samples are leached in duplicate. To date, the Wyodak sample has been leached (Wyodak-1,2) and the other two samples have been leached twice (Ohio-1,2,3,4; and North Dakota-1,2,3,4). All analytical data for these leaching tests have been returned, with the exception of $\mathrm{Hg}$ for the Wyodak-1,2, North Dakota-3,4, and Ohio-3,4 samples, which are being held for analysis by CVAF (see below). Repetition of the leaching procedure for the Ohio and North Dakota samples was necessitated by a problem with the normality of the $\mathrm{HNO}_{3}$ used for those samples in that step of the procedure. Review of the results for the Ohio-3,4, North Dakota-3,4, and Wyodak-1,2, samples indicates that there is also an intermittent problem in the $\mathrm{HNO}_{3}$ step due to incomplete consumption of pyrite when samples are leached in conicalbottomed centrifuge tubes, as outlined in Appendix B. Incomplete pyrite digestion was confirmed in several of these samples by reflected-light microscopy of polished residues, and in the SEM. Tests of the revised "flask" method, a modification of the ASTM procedure for determination of pyritic sulfur, indicate that pyrite digestion by this method is complete. 
Table 3-1. Trace Element Concentrations in Phase II Coals by Neutron Activation Analysis (As Received Basis)

\begin{tabular}{|l|l|l|l|l|l|l|}
\hline Element $(\mu \mathrm{g} / \mathrm{g})$ & Wyodak & + +/ & Ohio 5,6,7 & + +/- & ND Lignite & + +/- \\
\hline \hline $\mathrm{Si}$ & $\mathrm{ND}$ & & $\mathrm{ND}$ & & $\mathrm{ND}$ & \\
\hline $\mathrm{Al}$ & 5400 & 400 & 11100 & 390 & 5400 & 400 \\
\hline $\mathrm{Ti}$ & 530 & 160 & 670 & 190 & 330 & 120 \\
\hline $\mathrm{Fe}$ & 2300 & 170 & 15100 & 650 & 5300 & 350 \\
\hline $\mathrm{Ca}$ & 7900 & 680 & 1400 & 220 & 13000 & 540 \\
\hline $\mathrm{Mg}$ & 1700 & 540 & 760 & 450 & 3100 & 950 \\
\hline $\mathrm{Na}$ & 660 & 60 & 350 & 43 & 2400 & 180 \\
\hline $\mathrm{K}$ & 2300 & 1800 & 2500 & 780 & $<3200$ & \\
\hline $\mathrm{P}$ & $\mathrm{ND}$ & & $\mathrm{ND}$ & & $\mathrm{ND}$ & \\
\hline $\mathrm{Cl}$ & 62 & 26 & 880 & 120 & 170 & 55 \\
\hline $\mathrm{Li}$ & $\mathrm{ND}$ & & $\mathrm{ND}$ & & $\mathrm{ND}$ & \\
\hline $\mathrm{Be}$ & $\mathrm{ND}$ & & $\mathrm{ND}$ & & $\mathrm{ND}$ & \\
\hline $\mathrm{B}$ & $\mathrm{ND}$ & & $\mathrm{ND}$ & & $\mathrm{ND}$ & \\
\hline $\mathrm{Sc}$ & 1.40 & 0.09 & 3.90 & 0.25 & 1.20 & 0.09 \\
\hline $\mathrm{V}$ & 14.0 & 1.8 & 23.0 & 2.5 & 11.0 & 1.5 \\
\hline $\mathrm{Cr}$ & 7.3 & 0.6 & 19.0 & 1.7 & 8.5 & 1.1 \\
\hline $\mathrm{Mn}$ & 8.2 & 0.4 & 19.0 & 0.7 & 44.0 & 1.6 \\
\hline $\mathrm{Co}$ & 5.1 & 0.4 & 5.8 & 0.5 & 6.4 & 0.6 \\
\hline $\mathrm{Ni}$ & $\mathrm{ND}$ & & $\mathrm{ND}$ & & $\mathrm{ND}$ & \\
\hline $\mathrm{Cu}$ & $\mathrm{ND}$ & & $\mathrm{ND}$ & & $\mathrm{ND}$ & \\
\hline $\mathrm{Zn}$ & 52 & 13 & 39 & 9 & 57 & 14 \\
\hline $\mathrm{Ga}$ & 9.7 & 5.2 & 11.0 & 5.4 & 17.0 & \\
\hline $\mathrm{Ge}$ & $\mathrm{ND}$ & & $\mathrm{ND}$ & & $\mathrm{ND}$ & \\
\hline $\mathrm{As}$ & 1.4 & 0.2 & 19.0 & 1.9 & 8.1 & 0.8 \\
\hline $\mathrm{Se}$ & 1.08 & 0.75 & 1.40 & 0.77 & 1.50 & 1.40 \\
\hline $\mathrm{Br}$ & 0.3 & 23.0 & 6.2 & 1.9 & 0.5 \\
\hline $\mathrm{Rb}$ & 100 & 37 & 100 & 38 & 120 & 50 \\
\hline $\mathrm{Sr}$ & $\mathrm{ND}$ & & $\mathrm{ND}$ & & $\mathrm{ND}$ & \\
\hline $\mathrm{Y}$ & $\mathrm{ND}$ & & $\mathrm{ND}$ & & $\mathrm{ND}$ & \\
\hline $\mathrm{Zr}$ & & & & & & \\
\hline & & & 21.0 & 8.6 & 32.0 & 7.8 \\
\hline
\end{tabular}


Table 3-1. Trace Element Concentrations in Phase II Coals by Neutron Activation Analysis (As Received Basis) (Continued)

\begin{tabular}{|l|l|l|l|l|l|l|}
\hline Element $(\mu \mathrm{g} / \mathrm{g})$ & Wyodak & $-+/-$ & Ohio $5,6,7$ & + +- & ND Lignite & + +/ \\
\hline \hline $\mathrm{Nb}$ & $\mathrm{ND}$ & & $\mathrm{ND}$ & & $\mathrm{ND}$ & \\
\hline $\mathrm{Mo}$ & 1.5 & 0.4 & 7.6 & 1.8 & 0.7 & 0.3 \\
\hline $\mathrm{Ag}$ & $\mathrm{ND}$ & & $\mathrm{ND}$ & & $\mathrm{ND}$ & \\
\hline $\mathrm{Cd}$ & 0.24 & 0.20 & 0.40 & 0.30 & 0.21 & 0.20 \\
\hline $\mathrm{In}$ & 0.07 & 0.04 & 0.06 & 0.07 & 0.12 & 0.12 \\
\hline $\mathrm{Sn}$ & $\mathrm{ND}$ & & $\mathrm{ND}$ & & $\mathrm{ND}$ & \\
\hline $\mathrm{Sb}$ & 0.40 & 0.03 & 2.30 & 0.18 & 0.91 & 0.08 \\
\hline $\mathrm{Te}$ & $\mathrm{ND}$ & & $\mathrm{ND}$ & & $\mathrm{ND}$ & \\
\hline $\mathrm{Cs}$ & 2.50 & 0.50 & 0.63 & 0.30 & 0.50 & 0.36 \\
\hline $\mathrm{Ba}$ & 380 & 53 & 102 & 43 & 420 & 75 \\
\hline $\mathrm{La}$ & 4.00 & 0.25 & 9.40 & 0.60 & 3.10 & 0.33 \\
\hline $\mathrm{Ce}$ & 7.4 & 0.5 & 14.0 & 0.8 & 4.3 & 0.6 \\
\hline $\mathrm{Nd}$ & 2.6 & 0.6 & 11.0 & 2.1 & 1.8 & 0.6 \\
\hline $\mathrm{Sm}$ & 0.60 & 0.05 & 2.00 & 0.17 & 0.50 & 0.04 \\
\hline $\mathrm{Eu}$ & 0.25 & 0.08 & 0.38 & 0.15 & 0.27 & 0.08 \\
\hline $\mathrm{Tb}$ & $\mathrm{ND}$ & & $\mathrm{ND}$ & & $\mathrm{ND}$ & \\
\hline $\mathrm{Yb}$ & 0.30 & 0.06 & 1.10 & 0.20 & 0.40 & 0.10 \\
\hline $\mathrm{Lu}$ & 0.04 & 0.01 & 0.22 & 0.05 & 0.04 & 0.01 \\
\hline $\mathrm{Hf}$ & $\mathrm{ND}$ & & $\mathrm{ND}$ & & $\mathrm{ND}$ & \\
\hline $\mathrm{Ta}$ & $\mathrm{ND}$ & & $\mathrm{ND}$ & & $\mathrm{ND}$ & \\
\hline $\mathrm{W}$ & $\mathrm{ND}$ & & $\mathrm{ND}$ & & $\mathrm{ND}$ & \\
\hline $\mathrm{Au}(\mathrm{ng} / \mathrm{g})$ & 5.0 & 2.7 & 3.0 & 2.0 & 1.7 & 0.9 \\
\hline $\mathrm{Hg}$ & 0.13 & 0.01 & 0.15 & 0.01 & 0.13 & 0.01 \\
\hline $\mathrm{Tl}$ & $\mathrm{ND}$ & & $\mathrm{ND}$ & & $\mathrm{ND}$ & \\
\hline $\mathrm{Pb}$ & $\mathrm{ND}$ & & $\mathrm{ND}$ & & $\mathrm{ND}$ & \\
\hline $\mathrm{Bi}$ & $\mathrm{ND}$ & & $\mathrm{ND}$ & & $\mathrm{ND}$ & \\
\hline $\mathrm{Th}$ & 1.30 & 0.10 & 2.70 & 0.26 & 1.20 & 0.14 \\
\hline $\mathrm{U}$ & 0.70 & 0.05 & & & 0.80 & 0.06 \\
\hline & & & & & & \\
\hline
\end{tabular}

$\mathrm{ND}=$ Not Determined 
Table 3-2. Trace Element Concentrations in Phase II Coals on As Received Basis, Computed from USGS Analysis (See text for description).

\begin{tabular}{|c|c|c|c|}
\hline Element $(\mu \mathrm{g} / \mathrm{g})$ & Wyodak & Ohio 5,6,7 & ND Lignite \\
\hline $\mathrm{Si}$ & 9645 & 14096 & 18548 \\
\hline $\mathrm{Al}$ & 5490 & 6751 & 6677 \\
\hline $\mathrm{Ti}$ & 497 & 430 & 304 \\
\hline $\mathrm{Fe}$ & 2248 & 10906 & 5839 \\
\hline $\mathrm{Ca}$ & 8161 & 816 & 11129 \\
\hline $\mathrm{Mg}$ & 1410 & 252 & 2968 \\
\hline $\mathrm{Na}$ & 638 & 208 & 2819 \\
\hline K & 141 & 1187 & 1261 \\
\hline $\mathrm{P}$ & 423 & 200 & 126 \\
\hline $\mathrm{Cl}$ & ND & ND & ND \\
\hline $\mathrm{Li}$ & 2.7 & 8 & 3.8 \\
\hline $\mathrm{Be}$ & 0.3 & 2.6 & 0.8 \\
\hline B & 31 & 64 & 96 \\
\hline $\mathrm{Sc}$ & 1.4 & 2.8 & 1.4 \\
\hline $\mathrm{V}$ & 13 & 19 & 11 \\
\hline $\mathrm{Cr}$ & 5.9 & 11.4 & 8.5 \\
\hline $\mathrm{Mn}$ & 6.1 & 15 & 44 \\
\hline Co & 4.20 & 3.64 & 6.8 \\
\hline $\mathrm{Ni}$ & 3.6 & 13 & 3.2 \\
\hline $\mathrm{Cu}$ & 10 & 7.1 & 4.1 \\
\hline $\mathrm{Zn}$ & 6.1 & 16 & 9 \\
\hline $\mathrm{Ga}$ & 1.9 & 4 & 1.7 \\
\hline $\mathrm{Ge}$ & 0.27 & 7.3 & 1.0 \\
\hline As & 1.29 & 13.2 & 7.419 \\
\hline $\mathrm{Se}$ & 0.97 & 1.32 & 0.72 \\
\hline $\mathrm{Br}$ & 0.8 & 13.9 & 1.91 \\
\hline $\mathrm{Rb}$ & 1.6 & 8.4 & 5.3 \\
\hline $\mathrm{Sr}$ & 193 & 74 & 312 \\
\hline Y & 2.6 & 7.2 & 3.6 \\
\hline $\mathrm{Zr}$ & 13 & 10 & 19 \\
\hline
\end{tabular}


Table 3-2. Trace Element Concentrations in Phase II Coals on As Received Basis, Computed from USGS Analysis (Continued)

\begin{tabular}{|c|c|c|c|}
\hline Element $(\mu \mathrm{g} / \mathrm{g})$ & Wyodak & Ohio $5,6,7$ & ND Lignite \\
\hline $\mathrm{Nb}$ & 2.1 & 2.2 & 2.3 \\
\hline Mo & 0.8 & 3.6 & 1.7 \\
\hline $\mathrm{Ag}$ & $<0.2$ & $<0.2$ & $<0.3$ \\
\hline $\mathrm{Cd}$ & 0.1 & 0.1 & $<0.1$ \\
\hline In & ND & ND & ND \\
\hline $\mathrm{Sn}$ & $<0.9$ & 1 & $<1.5$ \\
\hline $\mathrm{Sb}$ & 0.17 & 1.44 & 0.52 \\
\hline $\mathrm{Te}$ & $<0.2$ & $<0.2$ & $<0.3$ \\
\hline Cs & 0.101 & 0.56 & 0.43 \\
\hline $\mathrm{Ba}$ & 334 & 49 & 438 \\
\hline $\mathrm{La}$ & 4.2 & 7.29 & 3.68 \\
\hline $\mathrm{Ce}$ & 6.9 & 13.7 & 5.8 \\
\hline $\mathrm{Nd}$ & ND & ND & ND \\
\hline $\mathrm{Sm}$ & 0.71 & 1.61 & 0.56 \\
\hline $\mathrm{Eu}$ & 0.143 & 0.317 & 0.111 \\
\hline $\mathrm{Tb}$ & 0.08 & 0.237 & 0.082 \\
\hline $\mathrm{Yb}$ & 0.31 & 0.73 & 0.36 \\
\hline $\mathrm{Lu}$ & 0.036 & 0.102 & 0.052 \\
\hline $\mathrm{Hf}$ & 0.44 & 0.45 & 0.45 \\
\hline $\mathrm{Ta}$ & 0.118 & 0.1 & 0.102 \\
\hline W & 0.36 & 0.8 & 2.22 \\
\hline $\mathrm{Au}(\mathrm{ng} / \mathrm{g})$ & $<0.9$ & $<1000$ & $<1.5$ \\
\hline $\mathrm{Hg}$ & 0.10 & 0.13 & 0.06 \\
\hline $\mathrm{Tl}$ & $<0.2$ & 1.0 & $<0.2$ \\
\hline $\mathrm{Pb}$ & 1.4 & 6.8 & 1.1 \\
\hline $\mathrm{Bi}$ & $<0.2$ & $<0.2$ & $<0.3$ \\
\hline Th & 1.37 & 1.59 & 1.24 \\
\hline $\mathrm{U}$ & 0.54 & 0.93 & 0.83 \\
\hline
\end{tabular}

$\mathrm{ND}=$ Not Determined 
Table 3-3. Ash Composition in Terms of Total Oxides (weight \%, sulfur-free basis)

\begin{tabular}{|l|r|r|r|r|r|r|r|r|r|}
\hline & \multicolumn{3}{|c|}{ (XRF) } & \multicolumn{3}{c|}{ (NAA-MIT) } & \multicolumn{3}{|c|}{ (NAA,etc.-USGS) } \\
\cline { 2 - 11 } & Wyodak & Ohio 5,6,7 & ND Lignite & Wyodak & Ohio 5,6,7 & ND Lignite & Wyodak & Ohio 5,6,7 & ND Lignite \\
\hline \hline $\mathrm{SiO}_{2}$ & 43.3 & 38.1 & 22.0 & ND & ND & ND & 34.2 & 50.0 & 65.8 \\
\hline $\mathrm{Al}_{2} \mathrm{O}_{3}$ & 17.2 & 39.4 & 20.4 & 16.9 & 21.6 & 10.9 & 17.2 & 21.2 & 20.9 \\
\hline $\mathrm{Fe}_{2} \mathrm{O}_{3}$ & 6.3 & 13.0 & 11.8 & 5.5 & 22.3 & 8.1 & 5.3 & 25.9 & 13.8 \\
\hline $\mathrm{TiO}_{2}$ & 1.4 & 2.0 & 0.5 & 1.5 & 1.2 & 0.6 & 1.4 & 1.2 & 0.8 \\
\hline $\mathrm{P}_{2} \mathrm{O}_{5}$ & 1.8 & 0.5 & 0.1 & ND & ND & ND & 1.6 & 0.8 & 0.5 \\
\hline $\mathrm{CaO}$ & 22.7 & 2.2 & 30.3 & 18.3 & 2.0 & 19.4 & 18.9 & 1.9 & 25.8 \\
\hline $\mathrm{MgO}$ & 4.0 & 1.0 & 8.0 & 4.7 & 1.3 & 5.5 & 3.9 & 0.7 & 8.2 \\
\hline $\mathrm{Na}_{2} \mathrm{O}$ & 1.7 & 0.9 & 5.1 & 1.5 & 0.5 & 3.4 & 1.4 & 0.5 & 6.3 \\
\hline $\mathrm{K}_{2} \mathrm{O}$ & 0.5 & 2.5 & 1.4 & 4.6 & 3.1 & $<4.0$ & 0.3 & 2.4 & 2.5 \\
\hline $\mathrm{BaO}$ & 0.7 & 0.2 & 0.5 & 0.7 & 0.1 & 0.5 & 0.6 & 0.1 & 0.8 \\
\hline $\mathrm{SrO}$ & 0.5 & ND & ND & 0.2 & 0.1 & 0.2 & 0.4 & 0.1 & 0.6 \\
\hline Total & 100.0 & 100.0 & 100.0 & & & & 85.3 & 104.6 & 146.1 \\
\hline
\end{tabular}

$\mathrm{ND}=$ Not Determined

Because of difficulties with the $\mathrm{HNO}_{3}$ leaching step, and the fact that it occurs at the end of the process, it is necessary to repeat the leaching procedure for each of the Phase II samples. When these leaching procedures are completed, we will have four to six problem-free replicates for each of the first three parts (ammonium acetate, $\mathrm{HCl}, \mathrm{HF}$ ) of the procedure. In addition, the residual material from the Ohio-3,4, North Dakota-3,4, and Wyodak-1,2 tests is available for releaching by the flask method to see if we can obtain the fraction of pyrite not digested previously. The second re-leaching will commence shortly. We hope that the third time will be the charm.

In order to integrate the XAFS and leaching approaches, the University of Kentucky has agreed to obtain XAFS spectra for leached residues. These are currently available for all but the $\mathrm{HNO}_{3}$ fractions, which must await the re-re-leaching mentioned above.

\subsubsection{Probe/SEM}

Preparation is underway for our use of the USGS SHRIMP-RG ion microprobe at Stanford University. Machine time has been reserved on this instrument for the week of 23 August. The initial study will attempt to confirm and quantify our Phase I finding that measurable $\mathrm{Cr}$ concentrations, and possibly other air toxics, are present in illite, one of the most abundant mineral constituents of bituminous coals. This work will utilize the $\mathrm{O}^{-}$ion source 
currently available at the SHRIMP-RG. Subsequent work on trace metals in sulfides and arsenic in fly ash, will utilize both the $\mathrm{O}^{-}$ion source, and a new $\mathrm{Cs}^{+}$ion source, now being tested. Tests on sulfides and fly ash during our initial visit to the SHRIMP-RG will depend on the status of the $\mathrm{Cs}^{+}$ion source at that time.

In preparation for use of the SHRIMP-RG, about $15 \mathrm{mg}$ of coarse (>60 mesh) material was separated from several grams of each of the Phase II coals, selected coals from Phase I, and from several other USGS coal samples. The goal is to obtain grains coarse enough to show natural clay partings in a coal matrix, which would provide the best opportunity of analyzing illite with the ion probe beam. Suitable grains were separated, and duplicate splits were made for preparation of polished grain mounts. One set of samples was sent to Stanford for preliminary tests of ionization of $\mathrm{Cr}$ in the illites. The other set of grains was retained for analysis and chemical mapping using the electron microprobe in Reston, VA. A USGS biotite standard, containing about 2.0 weight percent $\mathrm{Cr}_{2} \mathrm{O}_{3}$, and another Cr-bearing mica, available at Stanford, have been identified as likely natural standards for the illite study.

\subsubsection{Development of a New Procedure for $\mathrm{Hg}$}

We are still awaiting results of cold-vapor atomic fluorescence (CVAF) blank-level tests for high-purity and ultra-high purity $\mathrm{V}_{2} \mathrm{O}_{5}$ reagents. Preliminary tests indicate that the blank-level is controlled by $\mathrm{V}_{2} \mathrm{O}_{5}$. At the same time, we are investigating an alternate method, using a direct $\mathrm{Hg}$ analyzer. The direct analyzer offers several advantages, including 1) detection limits similar to those we are trying to achieve with CVAF. 2) no need for sample digestion, and consequently, no reagent blank-level problems, and 3) a high degree of automation using the available autosampler. The USGS Minerals program is currently testing such a system and finds it preferable to their fluorescence unit.

\subsection{Combustion Zone Transformations (UU, MIT)}

\subsubsection{Vaporization of Trace Metals During Combustion}

A meeting including personnel from MIT and Utah was held to discuss the NAA results from the initial experiments on loss of trace elements during devolatilization (see quarterly technical report for January 1999 to March 1999). The data suggested that about one third of some "low volatility" elements vaporized during coal devolatilization, but there was poor replication and the amount of metal vaporization was within experimental uncertainty. Possible problems include segregation of the metals within the char pellet, and counting times that were not optimal for the concentrations of several of the elements of interest. A plan for another round of testing has been developed and the visiting student who did the work will return to University of Utah this summer to conduct the experiments.

Trace metals in coal may take one or more of several paths in combustion systems. They could remain in the residual ash, become vaporized then recondense as submicron ash, or they may vaporize and remain in the vapor phase in the outgoing flue gas. In order to understand the behavior of trace metals, we must determine their concentration and mode of occurrence in the 
coal and relate that to their fate during combustion. The experiments will be conducted in the laminar entrained flow reactor that is now at the University of Utah (described in the quarterly technical report for October 1998 to December 1998). All combustion products will be pulled through the cascade impactor for size segregation. The gases will then be filtered through activated carbon to absorb any remaining metals. These samples will be sent to MIT for NAA.

Experiments will be conducted on three coals: Ohio (5/6/7), Wyodak, and North Dakota lignite. These will be burned at $1650 \mathrm{~K}$ with a series of oxygen concentrations: $0 \%, 20 \%, 50 \%$, and $100 \%$ oxygen. The balance of the gas will be either nitrogen or carbon dioxide. When combustion takes place in the presence of carbon dioxide, the metals should exist at the char particle surface in their oxidized states. In contrast, combustion in nitrogen should favor formation of more reduced metal species. The reaction temperature will vary depending on the gas composition and its thermal diffusivity (see Phase I Final Report). Coal will be fed at a rate of $0.02 \mathrm{~g} / \mathrm{min}$ for 1 to 2 hours. The vertical alignment of the furnace will ensure that all products will be available for analysis with no loss in the reactor.

After burning, the sample will be pulled through the cascade impactor. The impactor will operate with the preseparator and all stages will be lined with Durapore Millipore filters that have been greased with Apiezon $\mathrm{H}$ and dried. The grease will insure adhesion and prevent particles from bouncing to other stages. All stages will be weighed and the first three and last three stages will be combined and sent to MIT for NAA. The impactor will separate the large residual ash from the much smaller submicron ash that is formed by vaporization and recondensation of materials. The flue gas will then be filtered through activated carbon, which will also be analyzed using NAA to quantify the amount of metal that remains in the vapor phase.

A new student has been trained to use the laminar flow reactor and cascade impactor. Tests of the filter and grease stability at temperature have been conducted. The Durapore millipore filters melt at $171^{\circ} \mathrm{C}$. Trial runs to determine the loading curves for the cascade impactor and time necessary to obtain enough samples will take place during the next quarter.

\subsubsection{Measurement of Gas-Phase Mercury and Other Trace Metals}

In April the iodated charcoal used for vapor phase $\mathrm{Hg}$ collection was tested to see whether it collected other vapor phase metals. The tests were performed at PSI using the entrained flow reactor (EFR). The Pittsburgh coal from Phase I was burned at $1500^{\circ} \mathrm{C}$ at a rate of 1.34 grams per minute, a stochiometric ratio of 1.2, and a total gas flow of 14.2 liters per minute. The flow rate through the sorbent tubes was 1 liter per minute; with no quenching flow, the sorbents were at a temperature of about $300^{\circ} \mathrm{C}$. Tests of 2,10 and 50 minutes were run. The collection efficiency of a $200 \mathrm{mg}$ charcoal sorbent tube was measured by running two tubes in series; the efficiency was calculated as the difference between the amount of the element collected in the front and back sorbent tubes, divided by the amount in the front tube.

As expected, the charcoal in the front sorbent collected $100 \%$ of the vapor phase $\mathrm{Hg}$, and the amount of $\mathrm{Hg}$ collected increased linearly with the test duration; the amount of $\mathrm{Hg}$ collected in the 50 min test was $89 \pm 8 \mathrm{ng}$. The other element which was collected with $100 \%$ efficiency by 
the front sorbent was Se. The amount of Se collected also increased linearly with test duration; the amount of Se collected in the 50 min test was $620 \pm 260 \mathrm{ng}$. Other elements were checked for collection efficiency with particular attention paid to $\mathrm{As}, \mathrm{Br}, \mathrm{Cd}$, and $\mathrm{Sb}$. No other elements were collected quantitatively. Although some elements appeared to be collected in the front sorbent in the 50 min test, they were not collected in either of the 10 min tests. This was either due to fine particles being collected in the charcoal or in some of the moisture which condensed in the front tube in the longer test.

As a second check on the collection of the Se and $\mathrm{Hg}$, the amount of material collected in the charcoals were compared with that in the frit material and with the adjusted amounts collected on impactors from previous tests of this coal in Phase I. Only the Se and $\mathrm{Hg}$ showed significantly more material in the charcoal sorbent tubes (thus in the vapor phase) than in the frits or impactors.

A second round of charcoal efficiency tests will be run this summer with a heated $\left(200^{\circ} \mathrm{C}\right)$ Teflon filter upstream of the heated $\left(110^{\circ} \mathrm{C}\right)$ sorbents. This should exclude the collection of anything other than vapor phase material from the sorbents and will allow a gross but hopefully meaningful mass balance to be performed.

\subsection{Post-Combustion Transformations (UA, UC, UU)}

\subsubsection{Large Scale Integrated Combustion Studies}

\subsubsection{Baseline Studies of Ohio Coal}

The following information obtained during these experiments at the University of Arizona was reported in the quarterly technical report for October 1998 to December 1998:

1. A description of the experiments performed and the sample sets obtained

2. The sampling conditions for the most important sample sets

3. The typical steady-state temperature profile from these tests

The following information obtained during these experiments was reported in the quarterly technical report for January 1999 to March 1999:

1. Particle size distribution characterization for sample sets representing conditions at residence times of 0.5 seconds $(\sim 1350 \mathrm{~K})$ and 2.2 seconds $(\sim 1100 \mathrm{~K})$ as well as the hotside of the particulate removal device $(\sim 600 \mathrm{~K})$.

2. Preliminary size-segregated analytical results for these same sample sets.

3. An enrichment factor comparison for these same sample sets.

4. An elemental particle size dependence analysis for As, Se, Co, Cd, and Sb. 
Updated size-segregated analytical results for sample sets representing conditions at residences time of 0.5 seconds and 2.2 residence seconds and the hot-side of the particulate removal device are shown in Appendix C, Tables C-1 to C-9. Tables C-1 to C-3 document updated major species concentrations at the three conditions. In Tables C-4 to C-6, the major species data are normalized to provide typical size-segregated particle compositions. Tables C-7 to C-9 provide typical trace element concentrations for all elements analyzed by either GFAA or NAA techniques. The data shown in Tables C-1 to C-9 also include corrections to the elemental concentrations at a residence time of 2.2 seconds reported in the January 1999 through March 1999 quarterly report. Some of the 2.2 seconds data reported were actually values at 0.5 second.

The typical concentration values from Tables C-6 to C-9 of Appendix C were used to generate individual element distribution profiles (as described in Reference 1) for some of the more important trace elements (Figures 3-1 through 3-7). Cadmium results represent major outliers compared to the other results obtained and the information developed should be viewed with caution. We believe these results to be inaccurate. The Cd concentrations obtained from these experiments were abnormally high and are most likely the result of contamination from previous experiments conducted on this furnace involving cadmium. The arsenic concentration for the sample at 2.2 seconds from the 0.937 micron diameter impactor stage and the cesium concentration for the sample at 2.2 seconds from the 0.337 micron diameter impactor stage also appear to represent major outliers compared to the other results obtained for this sample set.

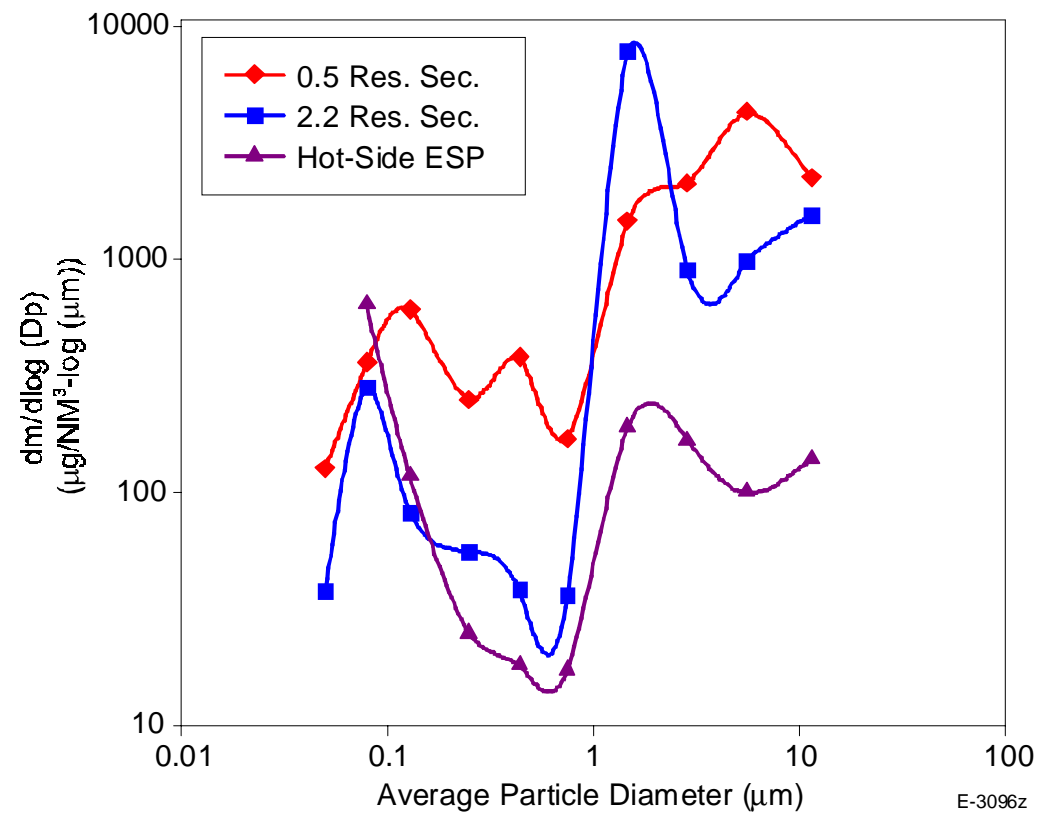

Figure 3-1. Typical arsenic distribution in Ohio baseline fly ash at various residence times. 


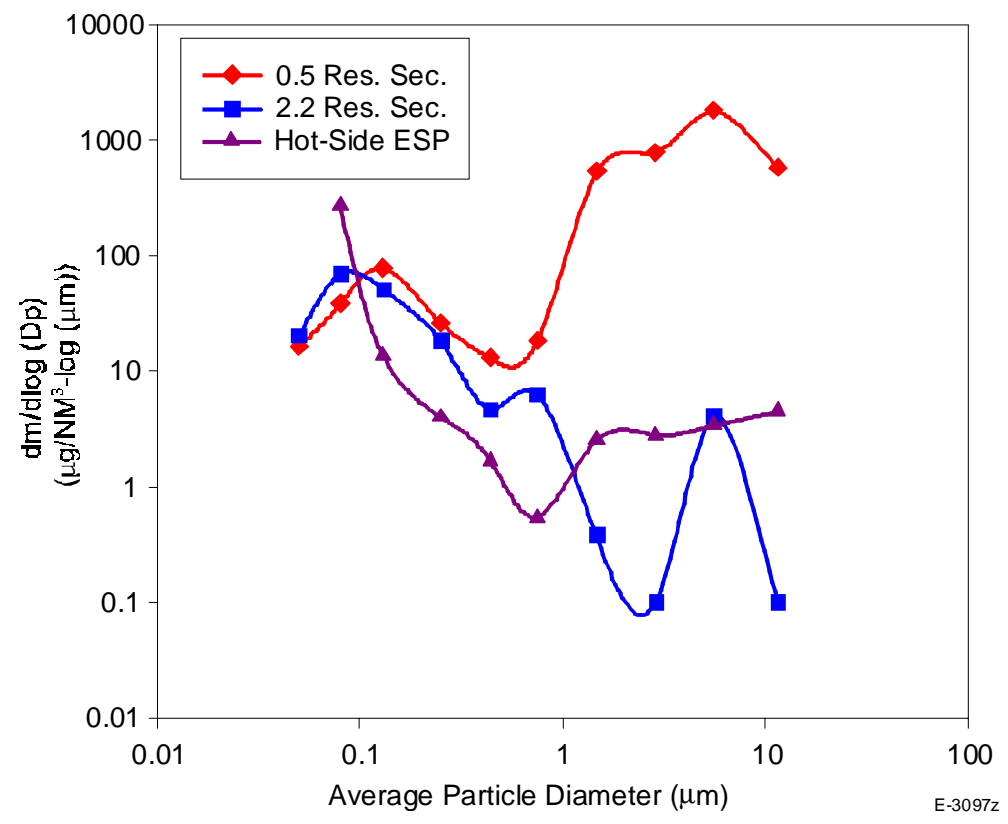

Figure 3-2.Typical selenium distribution in Ohio baseline fly ash at various residence times. (Note that $0.01 \mathrm{dM} / \mathrm{d} \log \left(\mathrm{D}_{\mathrm{p}}\right)$ values represent samples with selenium concentrations below the detection limit).

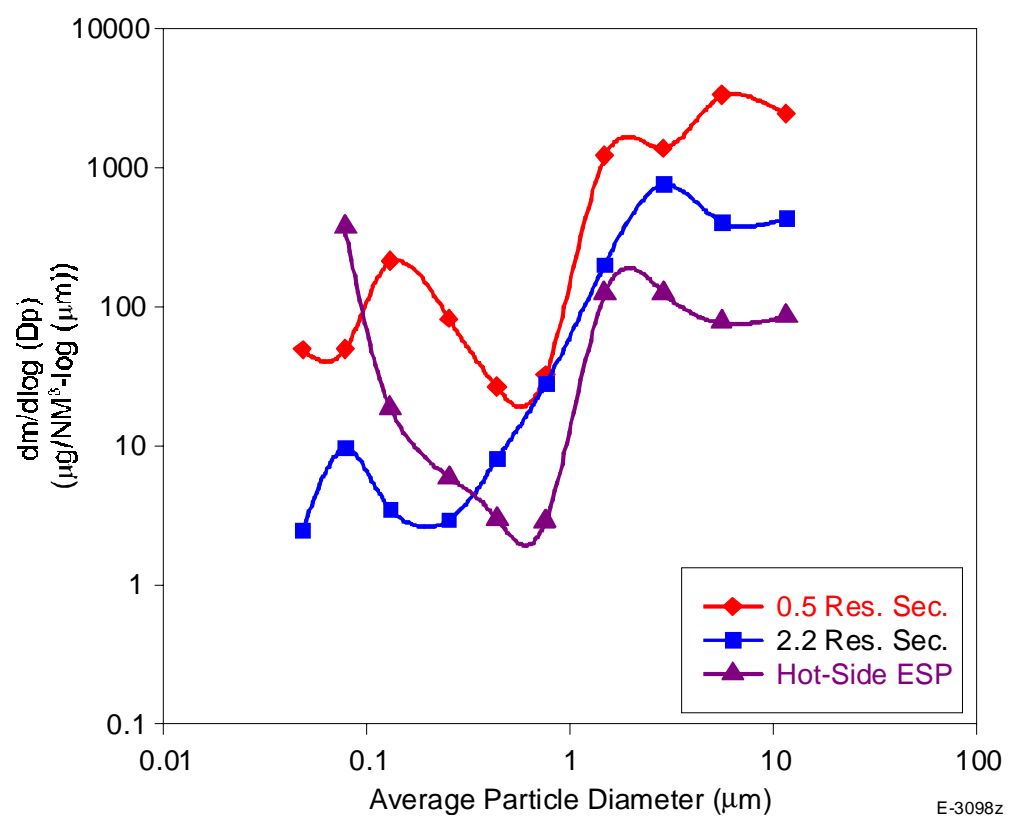

Figure 3-3. Typical cadmium distribution in Ohio baseline fly ash at various residence times. 


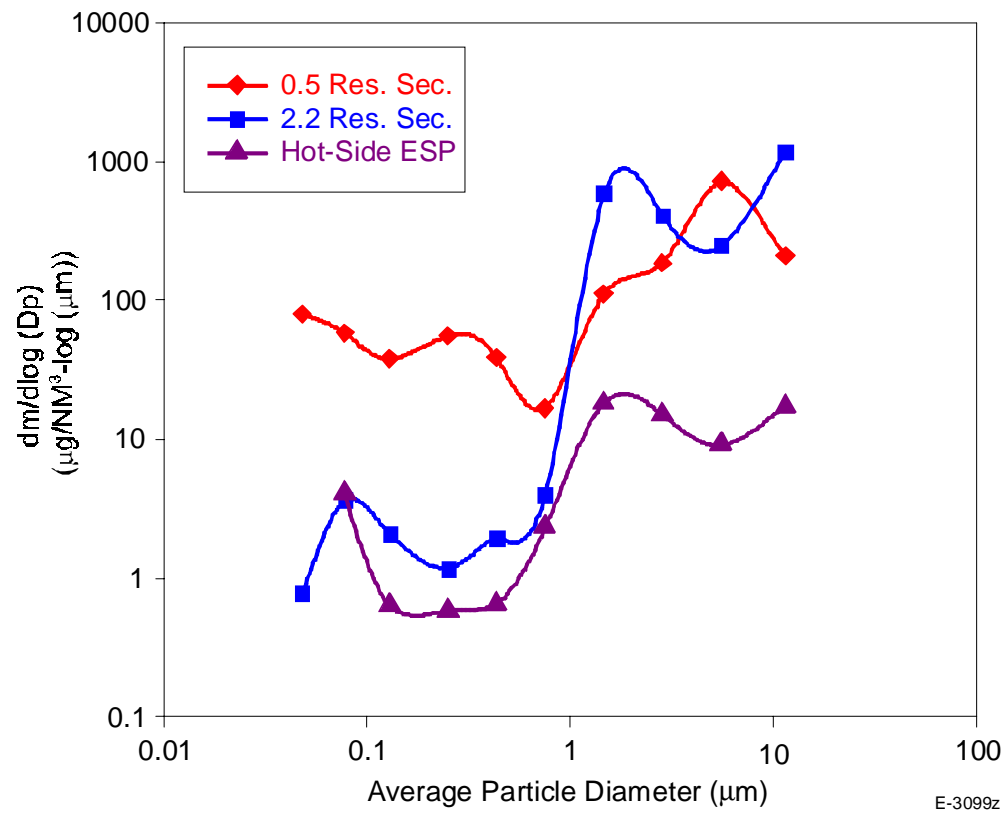

Figure 3-4. Typical cobalt distribution in Ohio baseline fly ash at various residence times.

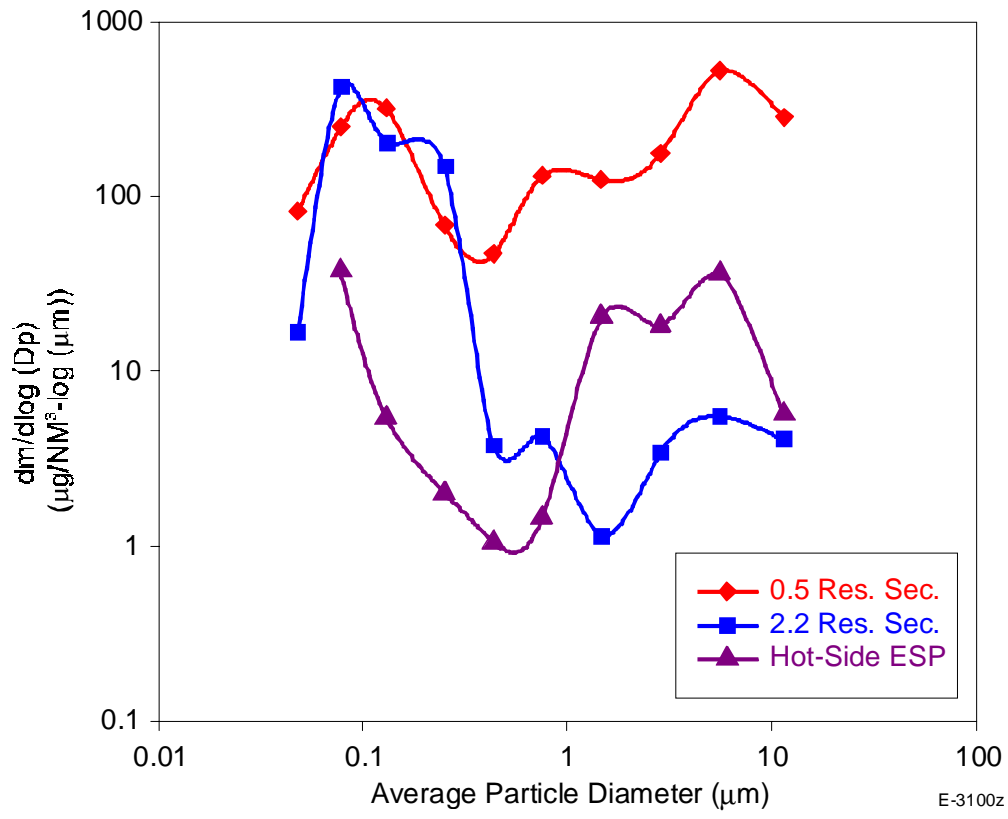

Figure 3-5. Typical antimony distribution in Ohio baseline fly ash at various residence times. 


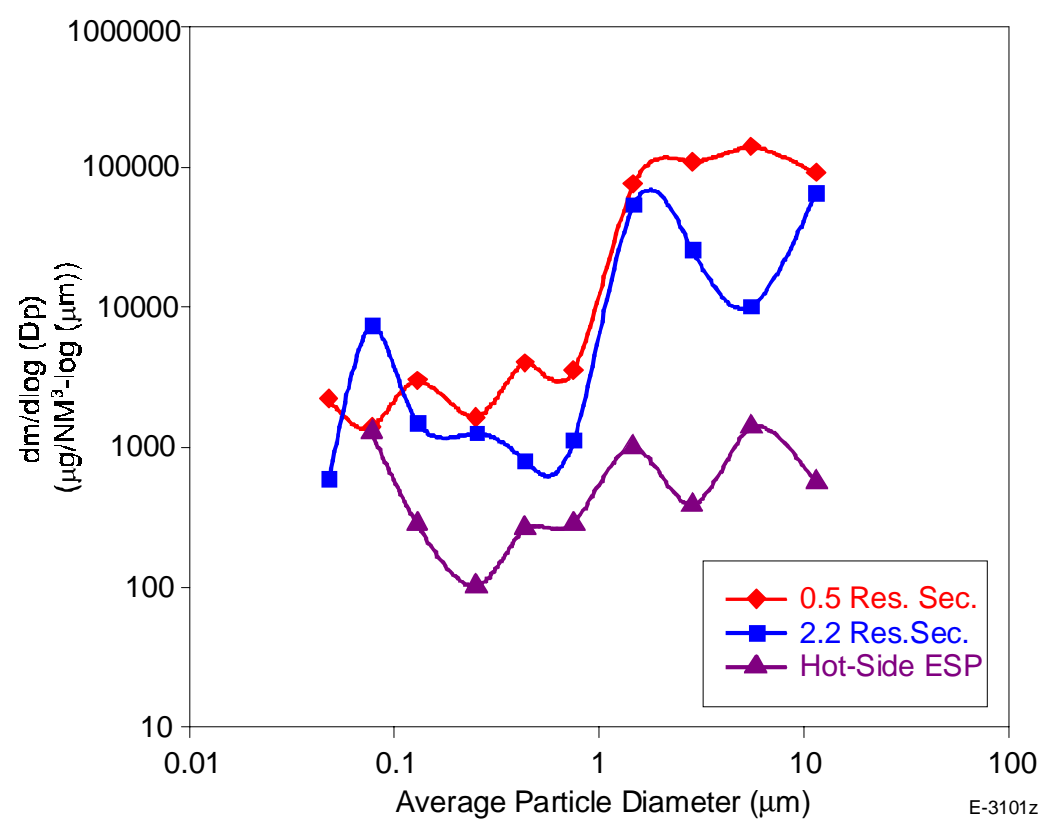

Figure 3-6. Typical chromium distribution in Ohio baseline fly ash at various residence times.

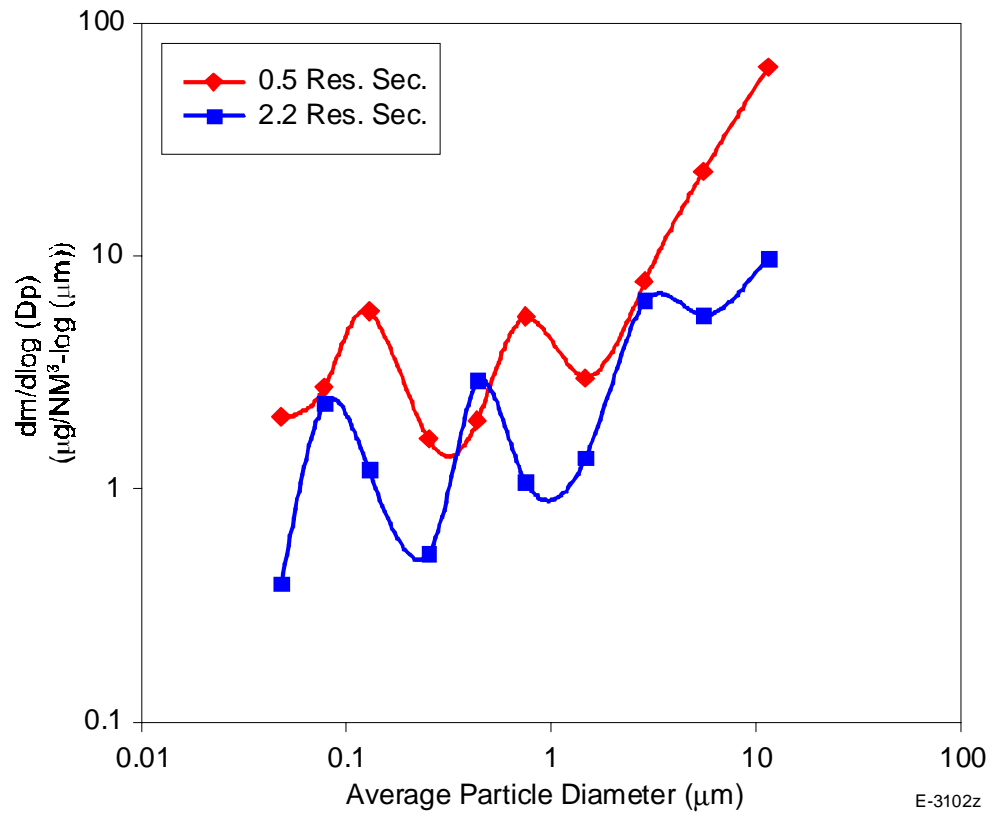

Figure 3-7. Typical cesium distribution in Ohio baseline fly ash at various residence times. 


\section{Vaporization}

Due to the sampling method employed, the smallest particle sizes (below about 0.1 microns) in the profile represent material that has vaporized and recondensed, either in the combustion gases or in the sample probe. Volatile elements present in the gas phase at the sampling temperature should condense homogeneously in the sample probe to form a fine aerosol. The rapid quench time in the sampling probe minimizes coagulation of this aerosol.

The normalized major species results in Tables C-4 to C-6 of Appendix C indicate that iron, silicon, and sodium compounds make up roughly $90 \%$ of the material collected in the first three impactor stages. Trace elements represent around 4\% of the material in these stages with the most prevalent being chromium, arsenic, and antimony.

\section{$\underline{\text { Submicron Region }}$}

The submicron impactor stages represent 1.1 to $4.4 \mathrm{wt} \%$ of the total mass of fly ash collected during these experiments. Trace elements can be present in submicron impactor stage samples by inclusion in submicron fragments, by vaporization and subsequent homogeneous nucleation, by vaporization and subsequent heterogeneous condensation onto submicron particle surfaces, or by vaporization and subsequent heterogeneous reaction with chemical species on/within submicron particle surfaces.

A commonly proposed mechanism for submicron particle formation involves vaporization and subsequent condensation of inorganic elements which are abundant in the coal, yet low in volatility (e.g., $\mathrm{Si}, \mathrm{Al}, \mathrm{Fe}$ ) to account for the majority of the submicron particles generated in the combustion zone. Since these submicron particles have a high specific surface area and high number density, heterogeneous transformation of the more volatile trace metals onto these submicron particles has been proposed as the mechanism dominating trace element vapor-tosubmicron particle transformation in the post-flame zone rather than homogeneous nucleation.

Of the major species analyzed, iron is dominant at 0.5 seconds with normalized values (see Table C-4 of Appendix C) of 57 to $83 \mathrm{wt} \%$ in the submicron region. Silicon concentrations range from 9 to $26 \mathrm{wt} \%$ in the submicron region. Aluminum concentrations are relatively low (around 2 wt $\%$ ) with comparable levels of calcium and chromium. Other important trace elements are As and $\mathrm{Sb}$.

Iron is also the dominant species at 2.2 seconds. Normalized values (see Table A-5 of Appendix A) range from 26 to $82 \mathrm{wt} \%$ in the submicron region. $\mathrm{Si}, \mathrm{Na}, \mathrm{Al}$, and $\mathrm{Cr}$ are the next most abundant elements under these conditions.

At hot-side ESP conditions, iron is still dominant in the submicron region. Sodium concentration is significant in the submicron particles at these conditions.

The individual metal particle size distribution data were normalized using an enrichment factor $\left(\mathrm{E}_{\mathrm{f}}\right)$ calculated by dividing the concentration of a specie from a given impactor stage by the 
average fly ash concentration of all impactor stages for that sampling condition. ${ }^{2}$ Enrichment factors are listed in Table 3-4. This normalization removes the effect of sample conditions upon the mass concentrations.

Comparing $\mathrm{E}_{\mathrm{f}}$ at 2.2 seconds to $\mathrm{E}_{\mathrm{f}}$ at 0.5 seconds $\left(\mathrm{DE}_{\mathrm{f}, 2.2-0.5}\right)$, provides insight into partitioning behavior in the post-combustion zone; particularly in the submicron region where other statistical methods yield less insight. When $\mathrm{DE}_{\mathrm{f}, 2.2-0.5}$ is negative for a particular particle size, this indicates a net loss of material from that size between 0.5 and 2.2 seconds. Examples of this type of comparison are shown in Figures 3-8 through 3-10 for As, Se, and Cs, respectively. For comparison, we have included $\mathrm{DE}_{\mathrm{f}, 2.2-0.5}$ results from Phase I Pittsburgh seam and Illinois No. 6 fly ash samples.

Arsenic Comparison Examining the differential enrichment factors $\left(\mathrm{DE}_{\mathrm{f}, 2.2-0.5}\right)$ in impactor stages with an aerodynamic diameter in the 0.09 to 0.54 micron range in Figure $3-8$, we find that there is a slight enrichment for the Illinois No. 6 fly ash arsenic distribution. These results suggest that volatilization and subsequent heterogeneous transformation to submicron particle surfaces is present but is probably not the most significant mechanism explaining arsenic presence in the submicron fly ash. Most of the arsenic in the submicron fly ash is probably contained in nonvolatilized fragments generated during the combustion process.

Figure 3-8 results for arsenic in Pittsburgh and Ohio fly ash samples are the reverse of those obtained from the Illinois No. 6 samples. Negative values for $\mathrm{DE}_{\mathrm{f}, 2.2-0.5}$ were calculated from the 0.09 through 0.54 micron cutoff diameter samples indicating that vapor-phase arsenic has been driven to the supermicron ash particles between 0.5 and 2.2 seconds. Thus, volatilization and subsequent heterogeneous transformation to submicron particle surfaces does not appear to be an important mechanism for the post-combustion phase partitioning of arsenic during the combustion of Pittsburgh seam or Ohio blend coal. These results suggest that virtually all of the arsenic in the submicron fly ash is contained in nonvolitalized fragments generated during the combustion process.

Selenium Comparison $\mathrm{DE}_{\mathrm{f}, 2.2-0.5}$ results for selenium are shown in Figure 3-9. The results show a large (on the order of 20 to 50) enrichment of selenium in the Ohio blend fly ash, a smaller magnitude enrichment of selenium in Illinois No. 6 fly ash submicron particles, and a depletion of selenium in Pittsburgh fly ash submicron particles. Thus, volatilization and subsequent heterogeneous transformation to submicron particle surfaces appears to be an important mechanism for the post-combustion phase partitioning of selenium during the combustion of the Illinois No. 6 and Ohio blend coals but not during combustion of the Pittsburgh seam coal. The large $\mathrm{DE}_{\mathrm{f}, 2.2-0.5}$ results for the Ohio blend coal must be tempered by the fact that the actual selenium concentrations are very low (see Tables C-7 to C-9 of Appendix C) and a relatively small increase in concentration will generate a large enrichment factor. However, the trend should still be valid. 
Table 3-4. Enrichment Factors $\left(\mathrm{E}_{\mathrm{f}}\right)$ for Ohio Fly Ash Sampled at 0.5 Seconds, 2.2 Seconds, and Hot-Side ESP Conditions

\begin{tabular}{|c|c|c|c|c|c|c|c|c|c|c|c|}
\hline Aerodynamic Diameter (50\% Cutoff), microns & 0.03 & 0.06 & 0.09 & 0.17 & 0.34 & 0.54 & 0.98 & 1.98 & 3.77 & 7.33 & 15.7 \\
\hline \multicolumn{12}{|l|}{0.5 Seconds } \\
\hline Total Fly Ash & 0.02 & 0.03 & 0.08 & 0.04 & 0.04 & 0.09 & 0.90 & 1.20 & 3.93 & 3.74 & 0.93 \\
\hline Arsenic & 5.79 & 6.37 & 5.81 & 4.97 & 5.84 & 1.47 & 1.44 & 1.47 & 0.93 & 0.58 & 0.87 \\
\hline Selenium & 2.38 & 2.16 & 2.36 & 1.65 & 0.64 & 0.50 & 1.67 & 1.72 & 1.23 & 0.47 & 0.42 \\
\hline Cadmium & 3.49 & 1.36 & 3.18 & 2.53 & 0.63 & 0.44 & 1.86 & 1.48 & 1.12 & 0.98 & 0.68 \\
\hline Cobalt & 30.32 & 8.49 & 3.01 & 9.21 & 4.96 & 1.20 & 0.91 & 1.07 & 1.28 & 0.45 & 0.47 \\
\hline Antimony & 24.50 & 28.61 & 19.83 & 8.81 & 4.67 & 7.40 & 0.80 & 0.79 & 0.73 & 0.48 & 0.69 \\
\hline Chromium & 2.76 & 0.66 & 0.78 & 0.88 & 1.68 & 0.83 & 2.02 & 2.05 & 0.82 & 0.64 & 0.82 \\
\hline Cesium & 9.30 & 4.78 & 5.52 & 3.25 & 3.02 & 4.73 & 0.29 & 0.54 & 0.49 & 1.66 & 0.57 \\
\hline \multicolumn{12}{|l|}{2.2 Seconds } \\
\hline Total Fly Ash & 0.03 & 0.10 & 0.06 & 0.03 & 0.01 & 0.02 & 0.88 & 3.21 & 1.81 & 3.55 & 1.31 \\
\hline Arsenic & 0.99 & 1.30 & 1.00 & 1.62 & 3.55 & 1.41 & 7.67 & 0.23 & 0.45 & 0.41 & 0.70 \\
\hline Selenium & 51.09 & 30.48 & 58.89 & 51.28 & 40.67 & 23.10 & 0.04 & & 0.18 & & 0.18 \\
\hline Cadmium & 0.48 & 0.33 & 0.32 & 0.63 & 5.55 & 8.06 & 1.47 & 1.42 & 1.37 & 0.85 & 0.51 \\
\hline Cobalt & 0.10 & 0.08 & 0.12 & 0.16 & 0.88 & 0.75 & 2.82 & 0.50 & 0.55 & 1.51 & 0.39 \\
\hline Antimony & 9.58 & 42.61 & 53.87 & 93.65 & 7.62 & 3.61 & 0.02 & 0.02 & 0.05 & 0.02 & 0.05 \\
\hline Chromium & 1.11 & 2.39 & 1.29 & 2.60 & 5.27 & 3.10 & 3.74 & 0.46 & 0.33 & 1.22 & 0.62 \\
\hline Cesium & 3.80 & 3.94 & 5.45 & 5.68 & 99.70 & 15.30 & 0.49 & 0.60 & 0.92 & 0.95 & 1.29 \\
\hline \multicolumn{12}{|l|}{ Hot-side ESP Conditions } \\
\hline Total Fly Ash & 0.04 & 0.21 & 0.24 & 0.10 & 0.06 & 0.08 & 1.35 & 1.27 & 1.45 & 3.71 & 2.48 \\
\hline Arsenic & & 12.48 & 3.24 & 1.86 & 1.61 & 1.35 & 1.10 & 0.96 & 0.51 & 0.31 & 1.03 \\
\hline \begin{tabular}{|l} 
Selenium \\
\end{tabular} & & 42.04 & 2.99 & 2.36 & 1.18 & 0.33 & 0.11 & 0.13 & 0.14 & 0.08 & 0.05 \\
\hline Cadmium & & 15.47 & 1.10 & 0.94 & 0.57 & 0.47 & 1.54 & 1.51 & 0.84 & 0.41 & 0.20 \\
\hline Cobalt & & 1.44 & 0.31 & 0.78 & 1.04 & 3.26 & 1.88 & 1.54 & 0.84 & 0.70 & 0.76 \\
\hline Antimony & & 7.57 & 1.55 & 1.55 & 0.98 & 1.17 & 1.22 & 1.08 & 1.92 & 0.14 & 0.96 \\
\hline Chromium & & 5.98 & 1.87 & 1.82 & 5.68 & 5.34 & 1.39 & 0.53 & 1.73 & 0.31 & 0.85 \\
\hline
\end{tabular}




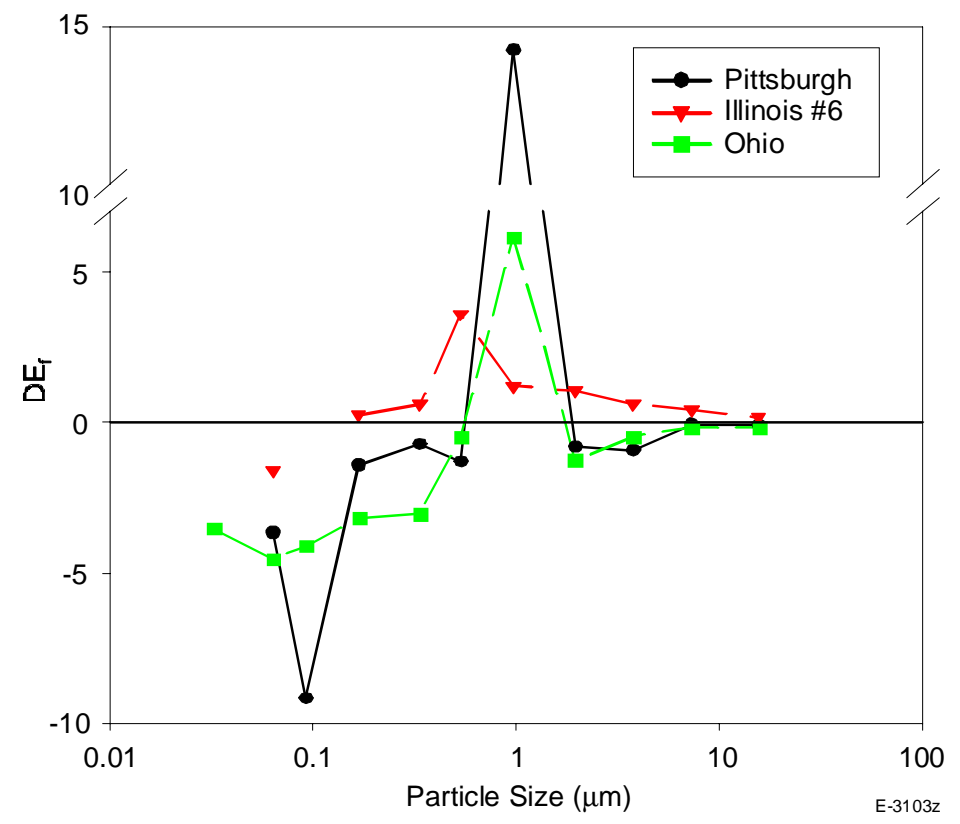

Figure 3-8. Arsenic differential enrichment factor comparison, $\left(\mathrm{E}_{\mathrm{f}, 2.2}-\mathrm{E}_{\mathrm{f}, 0.5}\right)$.

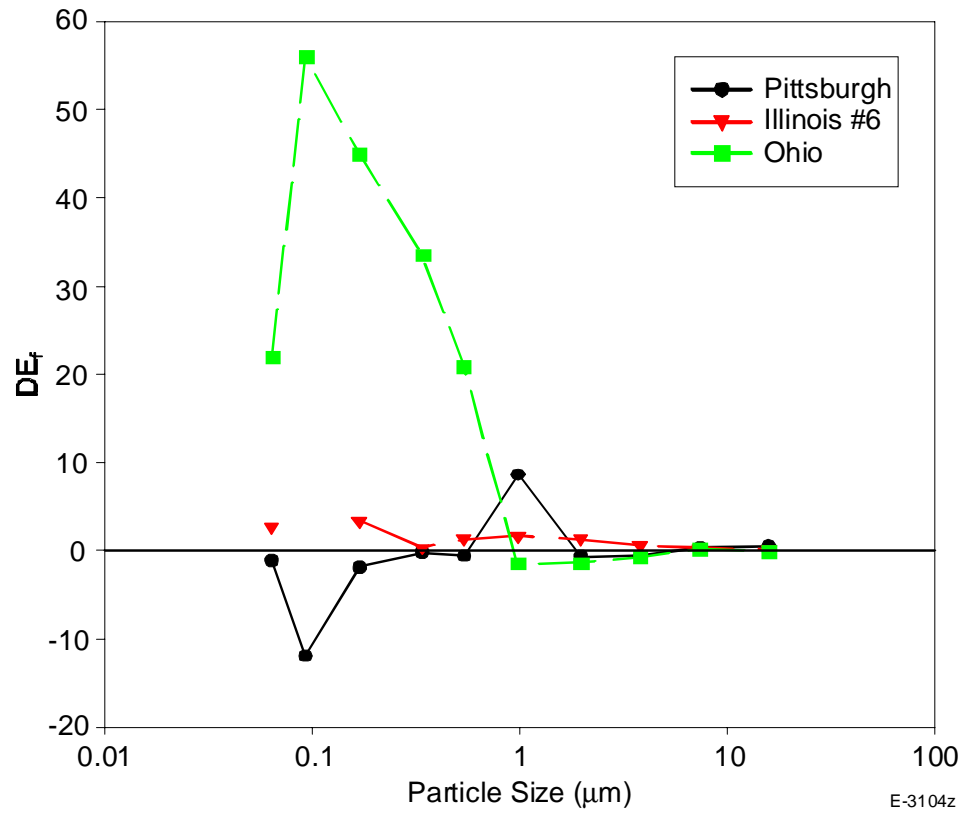

Figure 3-9. Selenium differential enrichment factor comparison, $\left(\mathrm{E}_{\mathrm{f}, 2.2}-\mathrm{E}_{\mathrm{f}, 0.5}\right)$. 


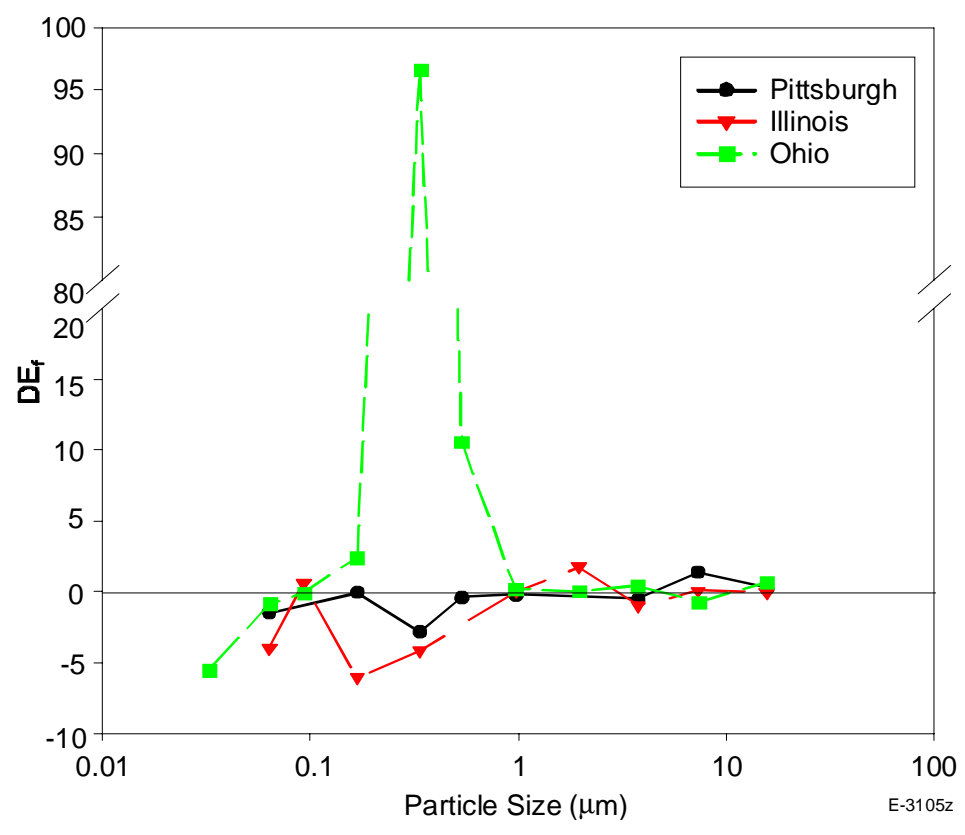

Figure 3-10. Cesium differential enrichment factor comparison, $\left(\mathrm{E}_{\mathrm{f}, 2.2}-\mathrm{E}_{\mathrm{f}, 0.5}\right)$.

A comparison of the partitioning behavior of selenium from the Pittsburgh seam coal to the selenium from the Ohio 5/6/7 blend coal is interesting since these coals have similar coal selenium concentrations yet very different fly ash distributions. In the size-segregated Pittsburgh fly ash, solid phase selenium in the 2.2 seconds samples is found primarily in the supermicron particles. By contrast, the size-segregated Ohio fly ash solid phase selenium in the 2.2 seconds samples is found primarily in the submicron particles. Further work is required to define why this difference occurs.

Cesium Comparison. Values of $\mathrm{DE}_{\mathrm{f}, 2.2-0.5}$ for cesium are shown in Figure 3-10 for all three coals. Positive values were generated for cesium in Ohio fly ash and negative values from the Pittsburgh seam and Illinois No. 6 fly ash samples. These results suggest that volatilization and subsequent heterogeneous transformation to submicron particle surfaces may be important for the post-combustion phase partitioning of cesium during the combustion of the Ohio blend coal but not during the combustion of Pittsburgh seam coal or Illinois No. 6 coal.

Because the hot-side ESP samples do not include all of the large size particles (this sample is obtained after two particle traps remove a significant portion of the large size particles), enrichment values from the hot-side ESP samples are not normalized to the same basis as those from the 0.5 and 2.2 seconds samples. Thus, they cannot be compared directly.

\section{$\underline{\text { Supermicron Region }}$}

Particles larger than 1 micron sampled at 0.5 seconds have typical concentrations of around 42 to $66 \mathrm{wt} \%$ iron, 16 to $29 \mathrm{wt} \%$ silicon, and 14 to $27 \mathrm{wt} \%$ aluminum. Trace elements 
only account for 0.4 to $1.4 \mathrm{wt} \%$ of the total material collected. Approximately $90 \%$ of the material categorized as trace elements consists of chromium. The next most significant trace elements are As, Cd (however, these values are artificially high due to contamination), and Se.

In the 2.2 seconds supermicron particles, the typical composition includes 29 to $36 \mathrm{wt} \%$ iron (with one outlier of $86 \mathrm{wt} \%$ ), 25 to $41 \mathrm{wt} \%$ silicon (with one outlier of $8 \mathrm{wt} \%$ ), and 26 to $41 \mathrm{wt} \%$ aluminum (with one outlier of $5 \mathrm{wt} \%$ ). Trace element content is 0.2 to $0.6 \mathrm{wt} \%$ of the total material collected. Over $90 \%$ of the material categorized as trace element consists of chromium. The next most significant trace elements are As, $\mathrm{Cd}$ (however, these values are artificially high due to contamination), and Co.

For the hot-side ESP supermicron particles, iron accounts for 41to $53 \mathrm{wt} \%$ and silicon accounts for 43 to $55 \mathrm{wt} \%$. Trace elements are 0.16 to $0.75 \mathrm{wt} \%$ of the total material collected with chromium accounting for around $90 \%$ of this material. $\mathrm{As}, \mathrm{Cd}$, and $\mathrm{Sb}$ concentrations were measured in the 80 to 700 ppm range.

The heterogeneous partitioning of trace metals onto supermicron-sized particles can occur by condensation of metal vapor upon existing particles and reaction of metal vapor with other chemical species on the surface or within the pores of a particle. The rate of transformation by reaction may be limited by diffusion of the metal vapor through the gas film surrounding the particle, diffusion into the pores of the particle, by the reaction rate on the exterior surface of a nonporous particle, or by the reaction rate on the internal surface within a porous particle. Log$\log$ plots of As, Se, and Cd concentration versus particle size in the 2.2 seconds samples can provide some insight into these heterogeneous partitioning mechanisms. A $1 / \mathrm{d}_{\mathrm{p}}$ (particle diameter) dependence indicates that, in the continuum regime, exterior surface reaction or pore diffusion controlled surface reaction may be the dominant formation mechanism. $1 / \mathrm{d}_{\mathrm{p}}{ }^{2}$ dependence indicates that gas film transfer is the controlling rate process; which is true for condensation in the continuum regime or for infinitely fast surface reaction. ${ }^{3}$ The results are shown in Figure 3-11 for As, Se, Cd, Co, Sb, Cr, and Cs from Ohio coal fly ash sampled at 2.2 seconds. No dependence on particle size is observed for As, Se, Sb, or Cs. There appears to be a 1/dp dependence for $\mathrm{Cd}$ (however all $\mathrm{Cd}$ results are suspect due to contamination in the furnace from previous experiments). The results for $\mathrm{Co}$ and $\mathrm{Cr}$ are inconclusive, depending on how much weight is attached to the 0.973 impactor stage results.

The Phase I results suggested that metal-calcium complexes may be an important mechanism for the heterogeneous transformation of semi-volatile trace elements in the supermicron region. The results in Figure 3-11 suggest that at least for most of the trace elements we examined (e.g., As, $\mathrm{Se}, \mathrm{Sb}, \mathrm{Cs}$, and possibly $\mathrm{Co}$ and $\mathrm{Cr}$ ) diffusion-controlled surface reaction is not an important partitioning mechanism for this Ohio blend coal. To explore the potential of metal-calcium reactions in the supermicron region as an important partitioning mechanism, the concentration of metal from a specific impactor stage (stages with a 50\% cutoff diameter of 0.97 microns or greater) was plotted versus the corresponding calcium concentration. If metalcalcium reactions are important, there should be a correlation between the metal concentration 


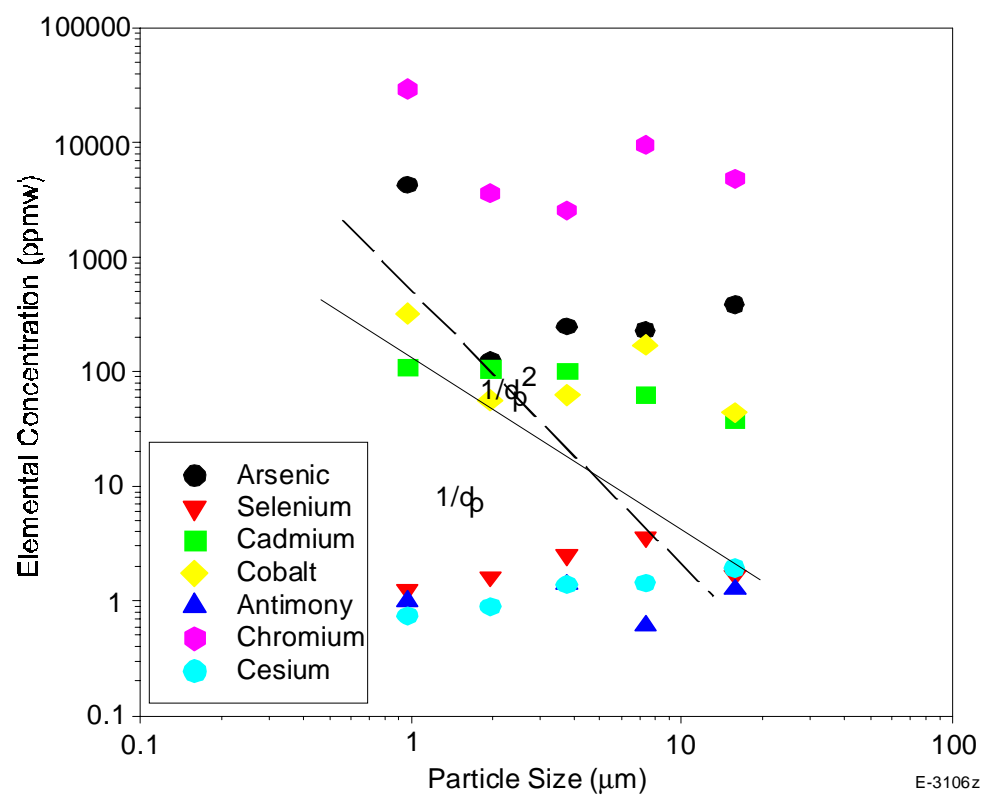

Figure 3-11. Particle size dependence of As, $\mathrm{Se}, \mathrm{Cd}, \mathrm{Co}, \mathrm{Sb}, \mathrm{Cr}$, and $\mathrm{Cs}$ from combustion of Ohio 5/6/7 Blend coal sampled at 2.2 seconds.

and calcium concentration for those impactor stages having a relatively low Ca concentration. One expects the data to deviate from the correlation at higher Ca concentrations since an excess of unbound $\mathrm{Ca}$ is likely to be present. The results are shown in Figures 3-12 through 3-17 for As, $\mathrm{Se}, \mathrm{Cd}, \mathrm{Co}, \mathrm{Sb}$, and $\mathrm{Cs}$, respectively.

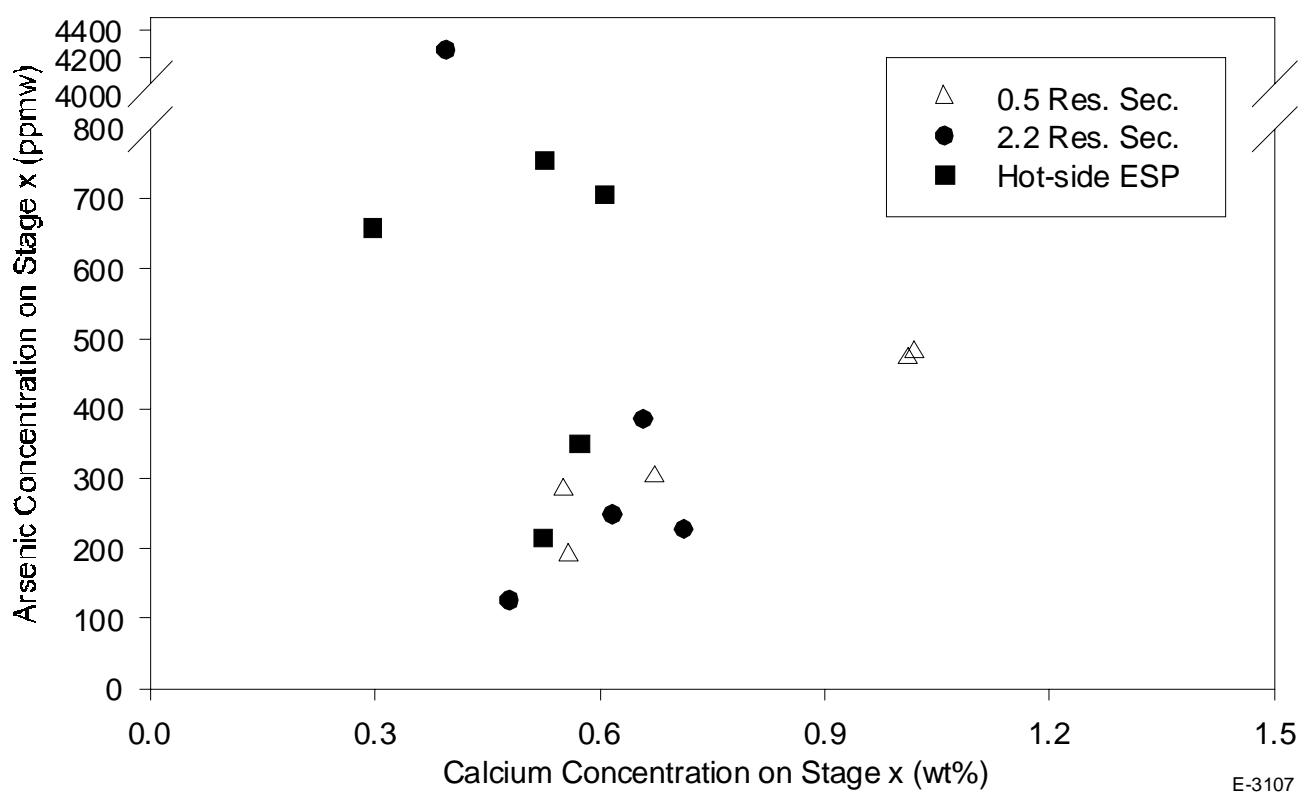

Figure 3-12. Arsenic-calcium correlation for Ohio Blend fly ash at various residence times. 


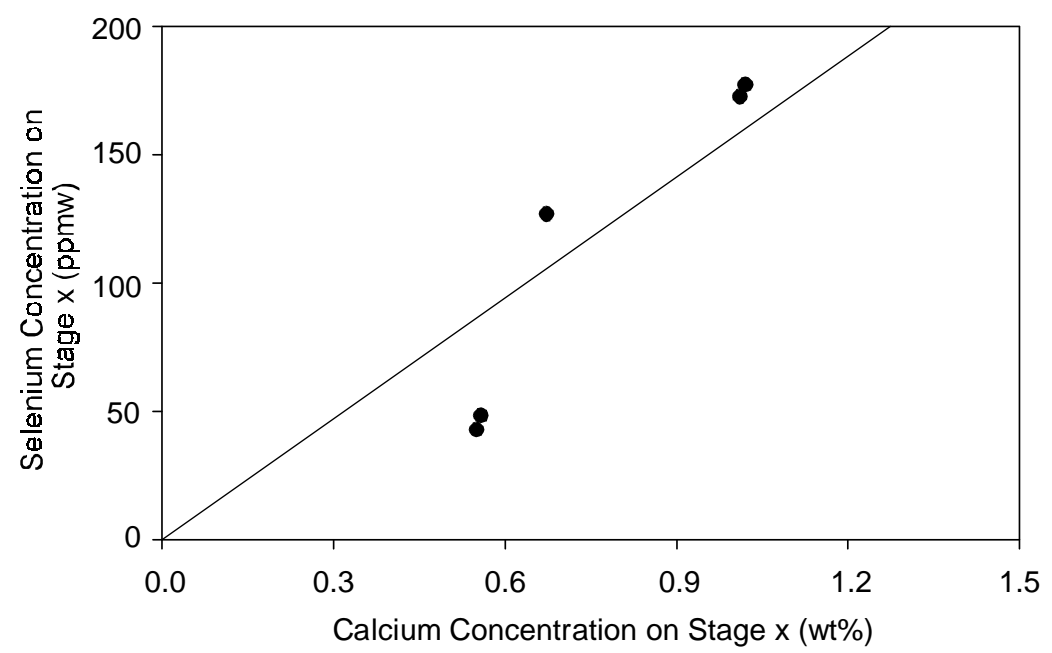

(a)

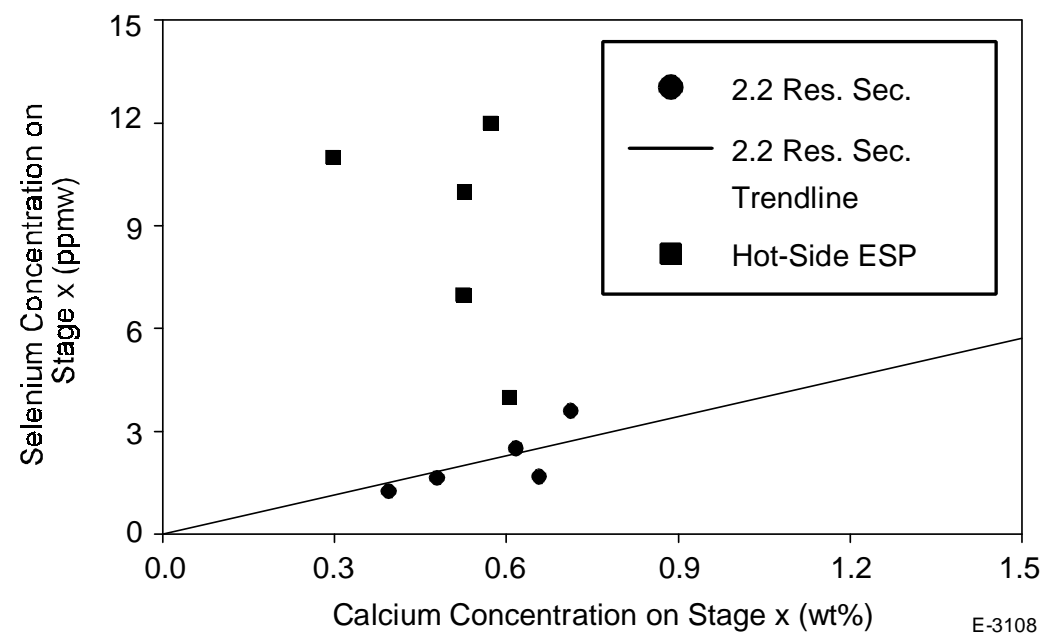

(b)

Figure 3-13. Selenium-calcium correlation for a) Ohio Blend at 0.5 seconds, and b) Ohio Blend at 2.2 seconds and hot-side ESP conditions.

In Figure 3-12 the concentration of As on a given stage is plotted versus the corresponding $\mathrm{Ca}$ concentration for the Ohio fly ash at all three sampling conditions. There appears to be no As-Ca correlation for the Ohio blend coal. The concentration of arsenic in the Ohio samples is substantially higher than in the other two coals while the calcium concentration is much lower. The amount of free calcium present under these conditions is probably insufficient to tie-up all of the arsenic present. This is consistent with the conclusions derived from Figure 3-11, above.

The concentration of Se on a given stage is plotted versus the corresponding $\mathrm{Ca}$ concentration for the Ohio test runs in Figure 3-13. The results indicate that there may be a Se-Ca correlation for both 0.5 and 2.2 seconds conditions despite the low Se and Ca concentrations in the coal. These results, coupled with the results from the Phase I coals implies that Se-Ca 


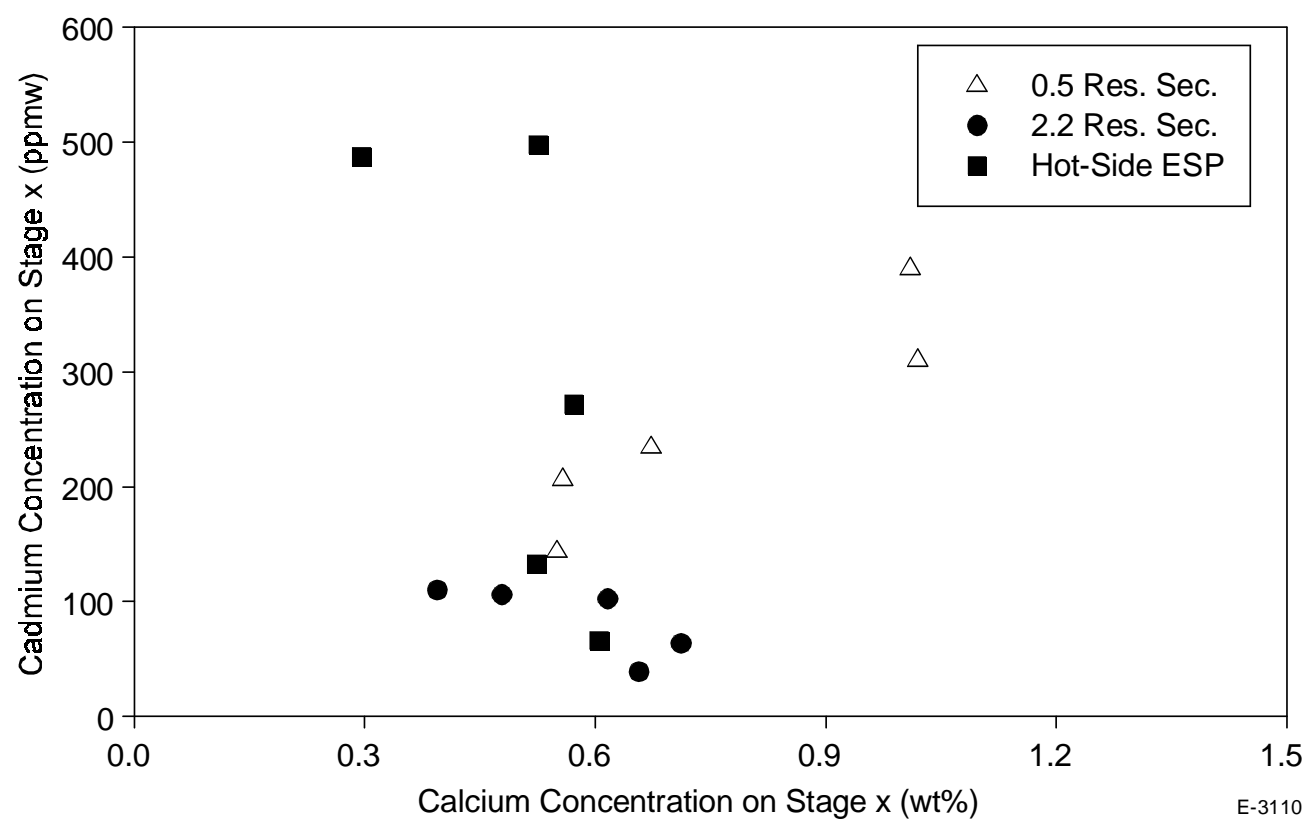

Figure 3-14. Cadmium-calcium correlation for Ohio Blend coal at various residence times.

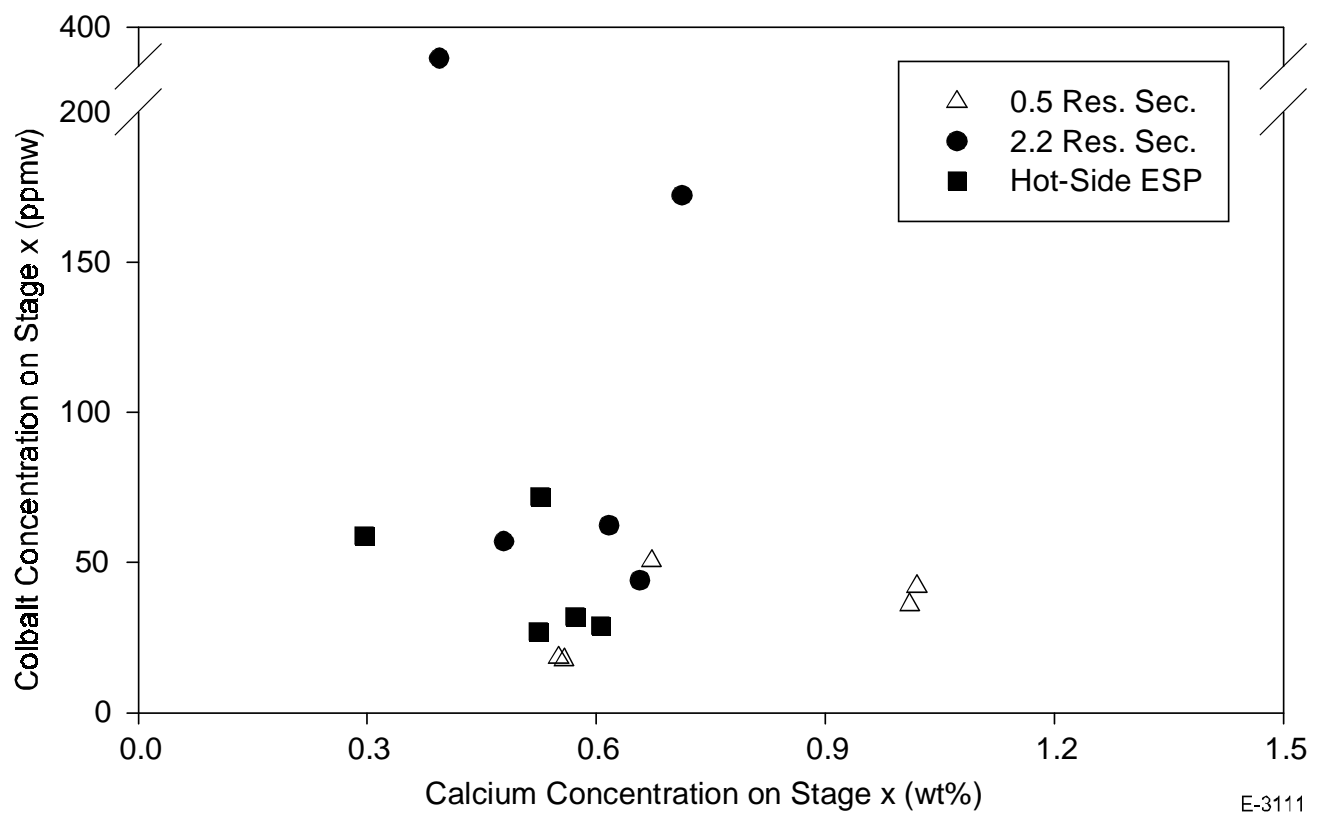

Figure 3-15. Cobalt-calcium correlation for Ohio Blend coal at various residence times. 


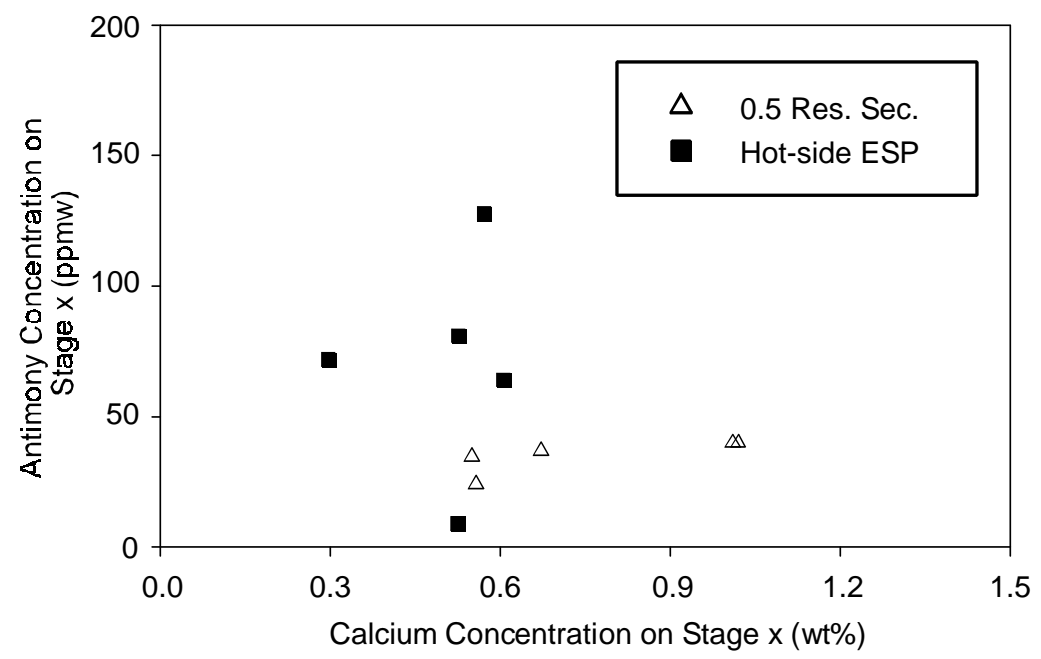

(a)

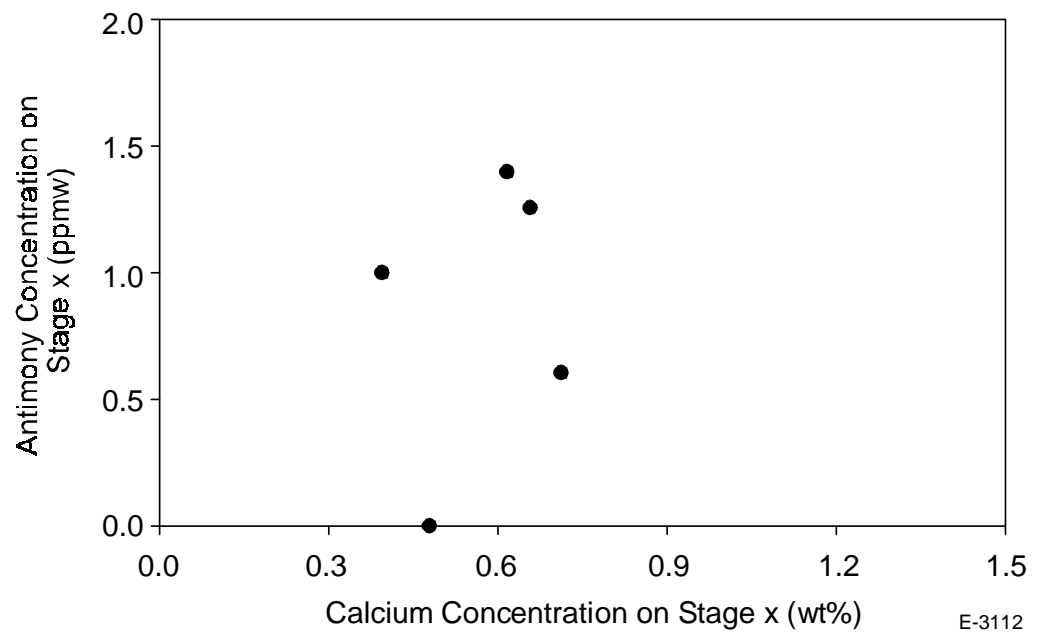

(b)

Figure 3-16. Antimony-calcium correlation for a) Ohio Blend at 0.5 seconds and hot-side ESP conditions and b) Ohio Blend at 2.2 seconds.

complexation is more reactive than As-Ca complexation. This observation is consistent with recently developed reaction kinetic data for calcium-based sorbents generated by L.S. Fan and coworkers $^{4,5}$ at Ohio State University. They report activation energies for Se-Ca and As-Ca reactions from coal combustion products onto Ca-based sorbents of $4 \mathrm{kcal} / \mathrm{gmole}$ and $10 \mathrm{kcal} /$ gmole, respectively.

In Figures 3-14 through 3-17 the concentration of $\mathrm{Cd}, \mathrm{Co}, \mathrm{Sb}$, and $\mathrm{Cs}$ on a given stage is plotted versus the corresponding $\mathrm{Ca}$ concentration for the Ohio fly ash. There appears to be no correlation between $\mathrm{Ca}$ and either $\mathrm{Cd}, \mathrm{Co}, \mathrm{Sb}$, or $\mathrm{Cs}$ for the Ohio blend coal.

Recent work by Amos and Wendt ${ }^{6}$ involving cesium sorption from lime indicates that cesium and calcium do not have the same degree of reactivity as As-Ca, Se-Ca, or Cd-Ca. However, they found that cesium is highly reactive with Al-based sorbents (e.g., kaolinite). By 


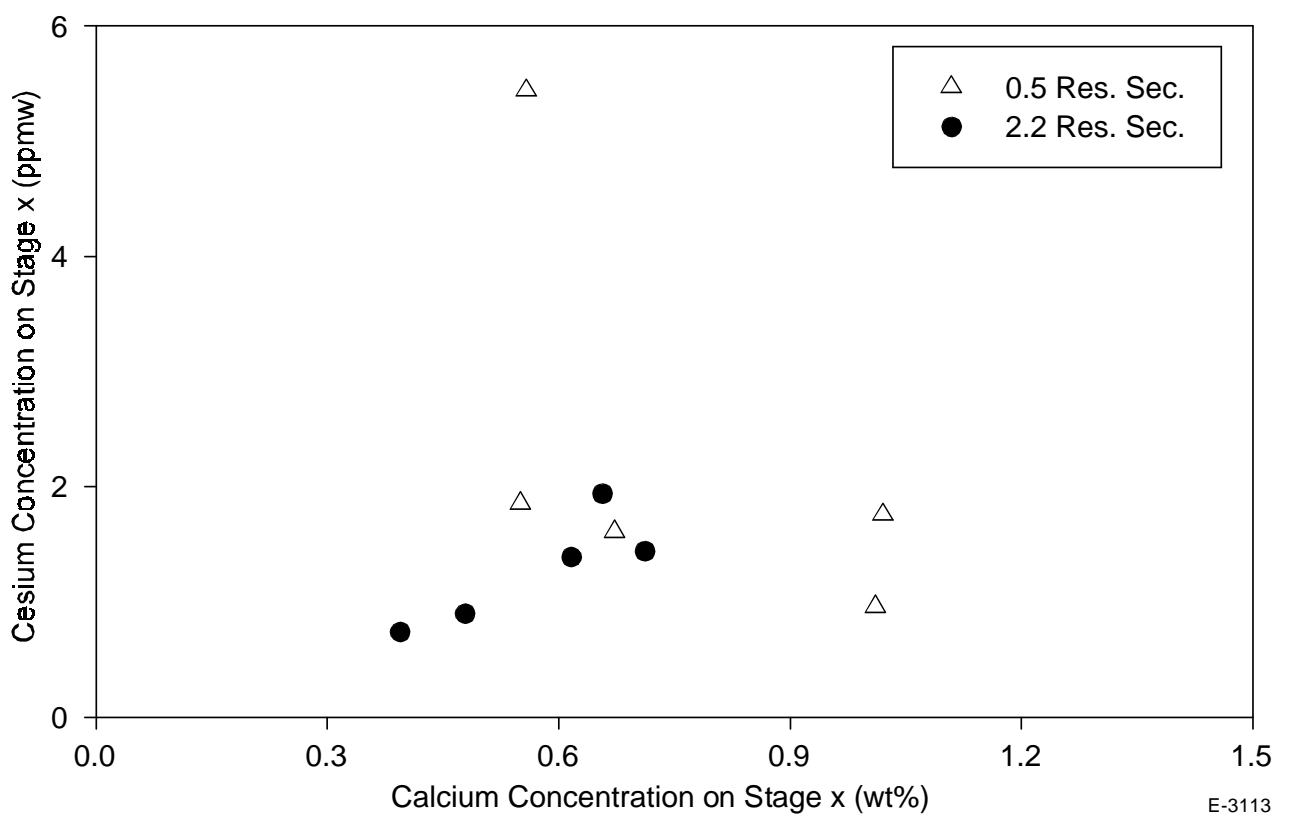

Figure 3-17. Cesium-calcium correlation for Ohio Blend fly ash at various residence times.

contrast, Fan and coworkers report that arsenic is much less reactive with Al-based sorbents than with Ca-based sorbents. To explore the significance of metal-aluminum complexing, the sizesegregated concentration of aluminum was quantified for the Ohio blend coal. As versus Al, Se versus Al, and Cs versus Al plots are shown in Figures 3-18 through 3-20, respectively. No correlation between As or Se concentration and $\mathrm{Al}$ concentration can be discerned from Figures 3-18 and 3-19.

The data in Figure 3-20 suggest a possible correlation at both sample locations. A trendline is included in Figure 3-20 for the 0.5 seconds results. All of the Al concentrations obtained at the 2.2 seconds sampling location cluster around $6.5 \mathrm{wt} \%$ Al. There is a fairly tight cluster of cesium concentrations for the corresponding impactor stages suggesting that $\mathrm{Cs}-\mathrm{Al}$ complexation may be a relevant mechanism for the partitioning of cesium in the supermicron region from the combustion of an Ohio 5/6/7 blend coal.

\subsubsection{Baseline Studies of Wyodak Coal}

The University of Arizona's pilot-scale downflow laboratory combustion furnace was used to test the partitioning of toxic metals in the Phase II baseline experiments for the Phase II Wyodak subbituminous coal. The objectives of these experiments were:

1. To obtain toxic metal partitioning data under test conditions which simulate the time/temperature combustion and post-combustion conditions of commercial scale utility boilers at $20 \%$ excess oxygen. 


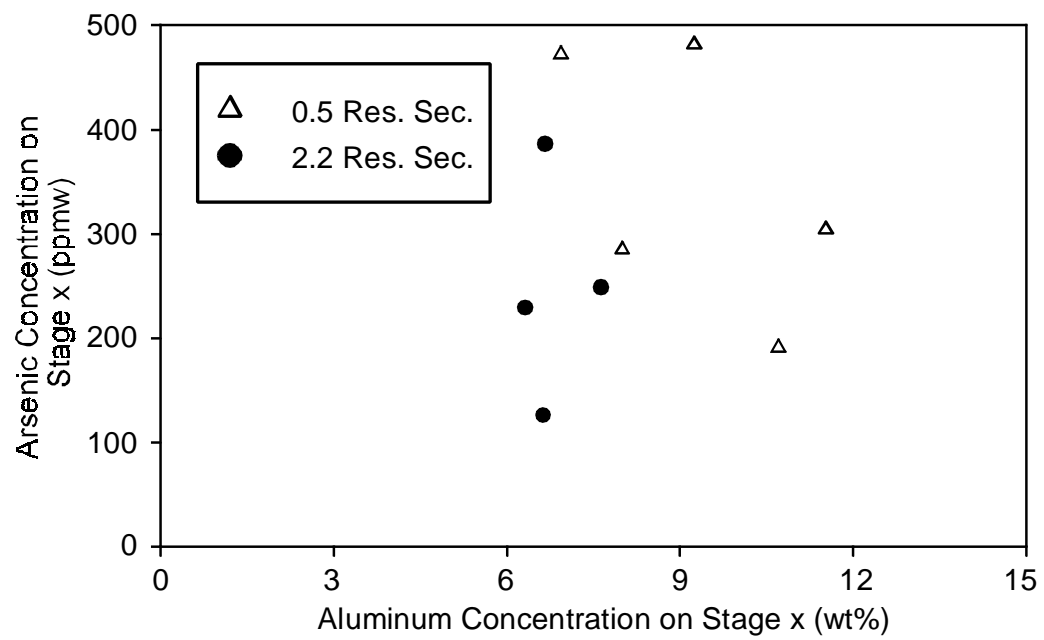

(a)

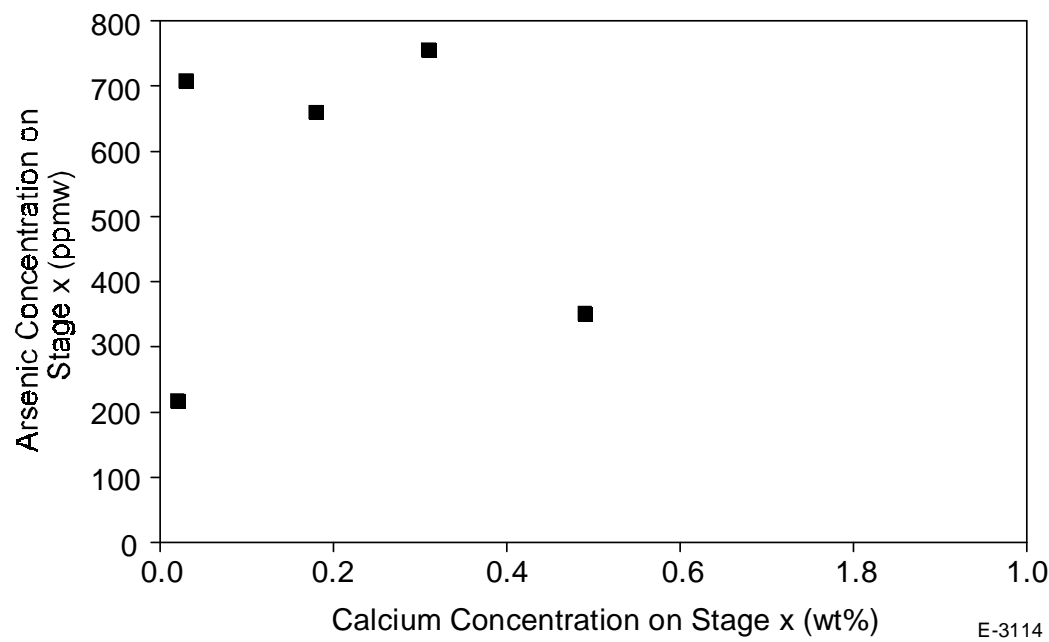

(b)

Figure 3-18. Arsenic-aluminum correlation for Ohio Blend fly ash a) 0.5 and 2.2 seconds and b) hot-side ESP conditions.

2. To investigate the differences in toxic metal partitioning from samples collected immediately after char burnout compared to samples collected near the furnace exit and to samples collected at the entrance to the baghouse.

A detailed description of the furnace and sampling systems is given in the Phase I Final Report. A Berner low pressure impactor (BLPI) was used for particulate sample collection for all of the experiments performed.

Sample collection media for the BLPI consisted of polycarbonate membranes sprayed with a high purity grease. The membranes were dried in a vacuum dessicator for a minimum of 24 hours. $1.5 \mathrm{ml} \mathrm{PVC}$ sample vials were used to contain the particulate-laden membranes. The vials were weighed with and without the particulate-laden membranes on a microbalance and 


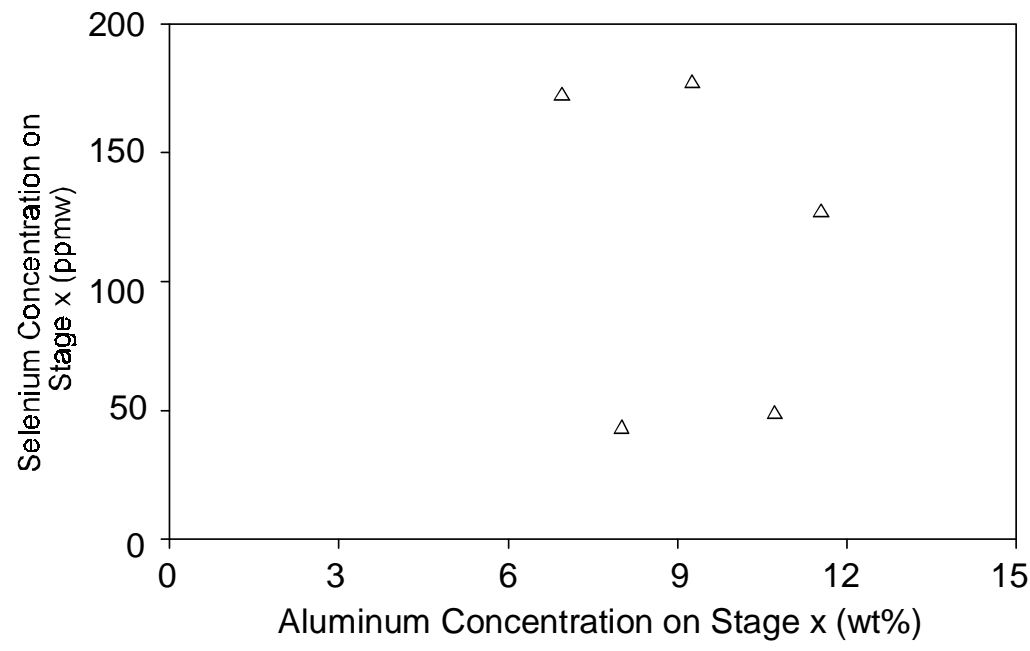

(a)

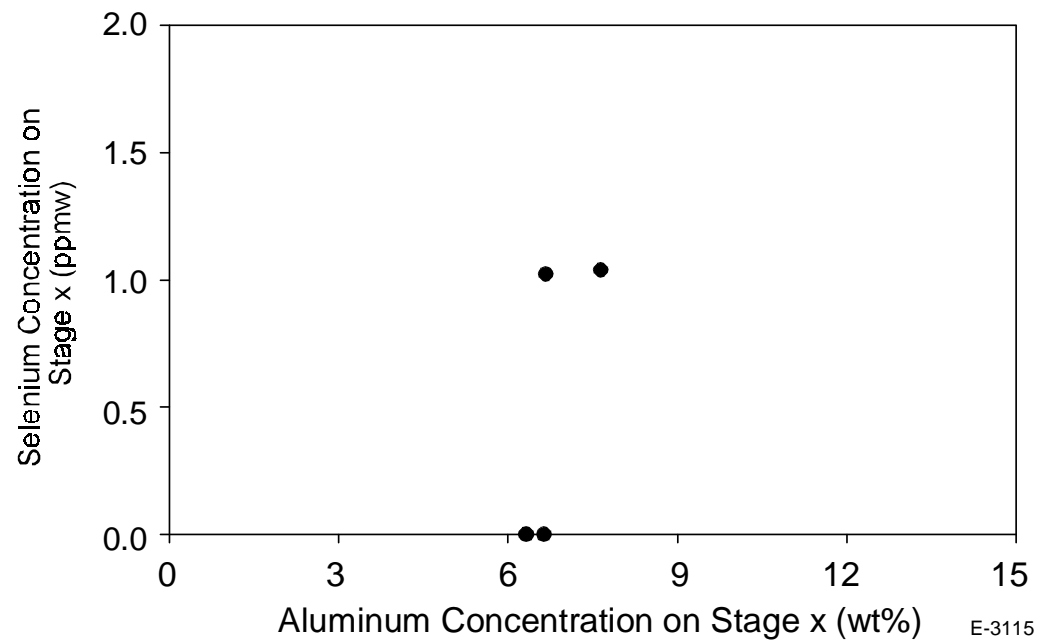

(b)

Figure 3-19. Selenium-aluminum correlation for Ohio Blend fly ash a) 0.5 and 2.2 seconds and b) hot-side ESP conditions.

stored in zip-loc sealed polyethylene bags. The dried sample media were also weighed on the microbalance just prior to loading into the BLPI. All microbalance weights were repeated. Two readings with a deviation of less than $0.00003 \mathrm{~g}$ were required before the weight data were accepted as accurate.

A total of 12 sets of particulate samples were collected during 6 test runs. All experiments were performed at a coal feed rate of $2.2 \mathrm{~kg} / \mathrm{hr}$. Due to the lower energy content of this subbituminous coal compared to the Ohio bituminous coal, combustion gases experienced a longer residence time in the furnace. We chose to sample particulate at the same locations as those sampled during the Ohio baseline tests. Five sets of particulate samples were collected from Port 4 (this port is at approximately the same location as Port 4B used in the Phase I 


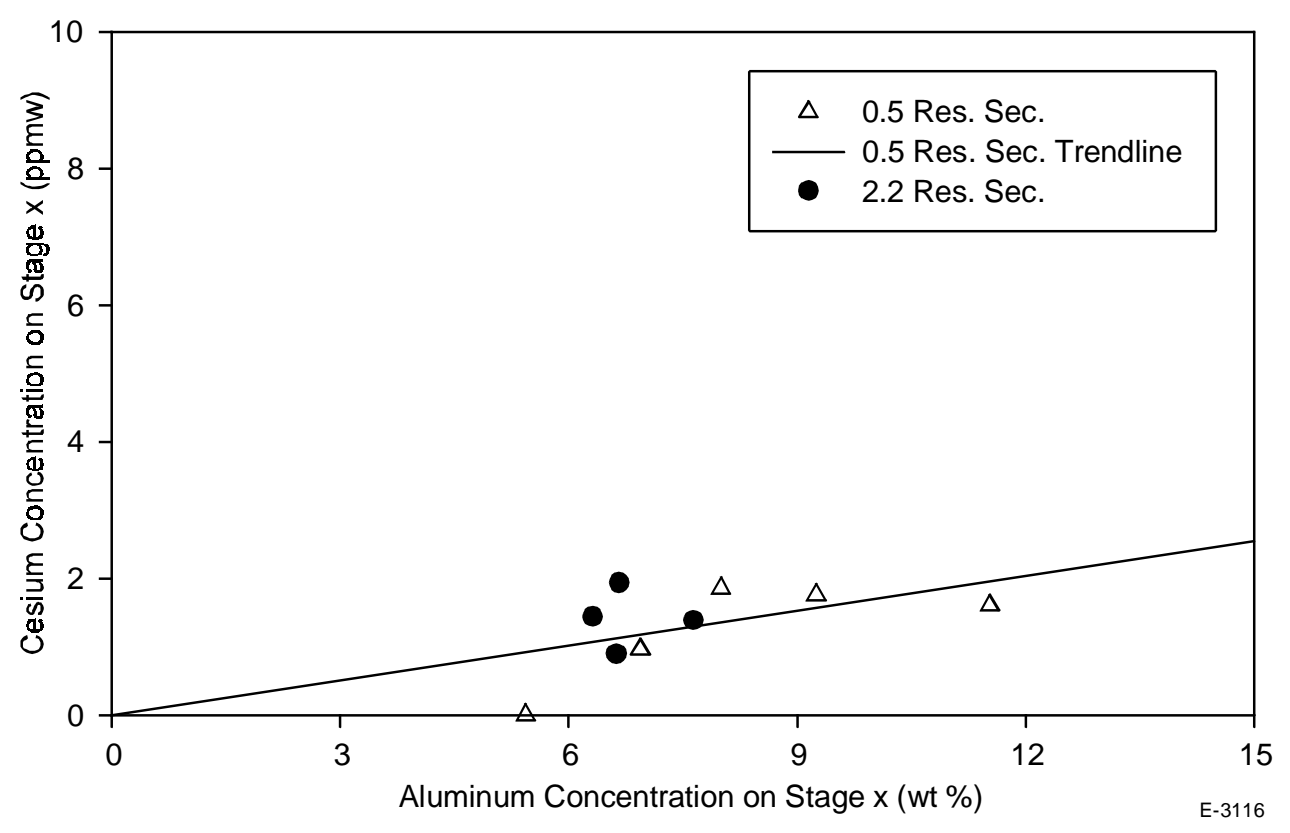

Figure 3-20. Cesium-aluminum correlation for Ohio blend fly ash.

experiments) of the furnace, which is located immediately after the end of the combustion zone (around 1.4 seconds from the burner). Four sets of particulate samples were collected from Port 14 (this port is at approximately the same location as Port 12 used in the Phase I experiments), which is located near the bottom of the furnace (around 6.6 seconds from the burner) and represents a snapshot of the flue gas in the post-combustion zone. These samples sets were typically taken immediately after one of the sample sets from Port 4 so that matched sample sets could be selected for analysis. Three sample sets were taken from the inlet to the baghouse and represent hot-side ESP sampling conditions. The baghouse samples are taken after partial segregation of large particles in an ash trap and a small particle trap. Each of these samples sets were taken immediately after one of the sample sets from Port 14 so that matched sample sets could be selected for analysis.

We found that a single collection test, performed without the BLPI inlet cyclone, could be used to collect all 11 size-segregated samples from the BLPI due to a smaller mean particle size for the Wyodak fly ash compared to the mean particle size for coals previously tested under this program. The sample sets and test runs are summarized in Table 3-5. Table 3-6 shows the sampling conditions for the most important sample sets. Figure 3-21 shows the typical steadystate temperature profile from these tests.

\section{$\underline{\text { Particle Size Distribution }}$}

Using the size-segregated ash weights collected in the BLPI in each test, particle size distributions (PSDs) were determined. Typical fly ash PSDs, developed following the method described by Markowski and Ensor, ${ }^{1}$ are shown in Figure 3-22. Figures 3-23 through 3-25 show 
Table 3-5. Summary of the Phase II Wyodak Baseline Test Runs

\begin{tabular}{|l|c|c|c|c|c|}
\hline Test Run \# & Date & Coal Feed Rate & Sample Set \# & Sampling Times & Sample Port Used \\
\hline \hline $99 \mathrm{~W}-0$ & $03 / 15 / 99$ & $2.2 \mathrm{~kg} / \mathrm{hr}$ & None $^{*}$ & & None \\
\hline $99 \mathrm{~W}-1$ & $03 / 19 / 99$ & $2.2 \mathrm{~kg} / \mathrm{hr}$ & $99 \mathrm{~W}-1 \mathrm{c}$ & $20 \mathrm{~min}$ & 4 \\
\hline & & & $99 \mathrm{~W}-1$ & $1 \mathrm{~min} 20 \mathrm{sec}$ & 4 \\
\hline & & & $99 \mathrm{~W}-2 \mathrm{c}$ & $38 \mathrm{~min}$ & 14 \\
\hline $99 \mathrm{~W}-2$ & $03 / 20 / 99$ & $2.2 \mathrm{~kg} / \mathrm{hr}$ & $99 \mathrm{~W}-3$ & $40 \mathrm{~min}$ & 14 \\
\hline & & & $99 \mathrm{~W}-4$ & $40 \mathrm{~min}$ & 4 \\
\hline & & & $99 \mathrm{~W}-5$ & $1 \mathrm{hr}$ & BG $^{\dagger}$ \\
\hline $99 \mathrm{~W}-3$ & $03 / 22 / 99$ & $2.2 \mathrm{~kg} / \mathrm{hr}$ & $99 \mathrm{~W}-6$ & $40 \mathrm{~min}$ & 4 \\
\hline & & & $99 \mathrm{~W}-7$ & $40 \mathrm{~min}$ & 14 \\
\hline & & & $99 \mathrm{~W}-8$ & $1 \mathrm{hr}$ & BG \\
\hline $99 \mathrm{~W}-4$ & $03 / 26 / 99$ & $2.2 \mathrm{~kg} / \mathrm{hr}$ & $99 \mathrm{~W}-9$ & $40 \mathrm{~min}$ & 4 \\
\hline & & & $99 \mathrm{~W}-10$ & $40 \mathrm{~min}$ & 4 \\
\hline & & & $99 \mathrm{~W}-11$ & $40 \mathrm{~min}$ & 14 \\
\hline
\end{tabular}

${ }^{*}$ Complete temperature and gas profiles were obtained using this run.

${ }^{\dagger}$ BG-Baghouse inlet sample port

Complete temperature and gas profiles were obtained using this run.

PSDs for individual sample sets at each of the three sampling locations. These figures provide insight into the variability in the PSDs shown in Figure 3-22. At all three sample locations, a typical bimodal PSD is observed, although the dip between the two regions is not as pronounced as for other coals studied. The submicron fume maximum occurs at around 0.1 microns.

The supermicron profile is flatter at the large particle end than previous coals studied due to the smaller mean particle size of the Wyodak fly ash particles. It should be noted that the large-size particle distribution for the Hot-Side ESP sample is artificially depressed because some of the large-size particles drop out of the gas phase prior to this sample collection point. However, a much smaller percentage of particles were collected in the particle traps upstream of the hot-side ESP sample location compared to previous coals studied. Even with these knock-out 
Table 3-6. Summary of Experimental Sampling Conditions for Wyodak Baseline Combustion

\begin{tabular}{|c|c|c|c|c|c|c|c|c|c|}
\hline $\begin{array}{c}\text { Sample Set \# } \\
\text { (Port } \\
\text { Sampled) } \\
\end{array}$ & $\begin{array}{c}\text { Total } \\
\text { Combustion } \\
\text { Gas Rate } \\
\text { (Slpm) } \\
\end{array}$ & $\begin{array}{c}\text { Samplin } \\
\text { g } \\
\text { Rate } \\
\text { (Slpm) } \\
\end{array}$ & $\begin{array}{c}\text { Sampling Temp. } \\
\left({ }^{\circ} \mathrm{K} \text { at Port where }\right. \\
\text { sample was } \\
\text { taken }) \\
\end{array}$ & $\begin{array}{c}\begin{array}{c}\text { Port } 4 \\
\mathrm{O}_{2} \text { Conc } \\
(\%)\end{array} \\
\end{array}$ & $\begin{array}{c}\text { Port } 4 \\
\mathrm{CO}_{2} \text { Conc } \\
(\%) \\
\end{array}$ & $\begin{array}{c}\text { Port } 14 \\
\mathrm{O}_{2} \text { Conc } \\
(\%) \\
\end{array}$ & $\begin{array}{c}\text { Port } 14 \\
\mathrm{CO}_{2} \text { Conc. } \\
(\%) \\
\end{array}$ & $\begin{array}{c}\begin{array}{c}\text { Port } \mathrm{BG}^{*} \\
\mathrm{O}_{2} \text { Conc. } \\
(\%)\end{array} \\
\end{array}$ & $\begin{array}{c}\text { Port BG } \\
\mathrm{CO}_{2} \text { Conc. } \\
(\%) \\
\end{array}$ \\
\hline $\begin{array}{l}99 \mathrm{~W}-3 \\
\text { (4) }\end{array}$ & 222 & 0.73 & 1058 & 3.7 & 16.3 & & & & \\
\hline $\begin{array}{l}99 \mathrm{~W}-4 \\
(14)\end{array}$ & 277 & 0.93 & 738 & 3.7 & 16.3 & 7.5 & 12.8 & & \\
\hline $\begin{array}{l}99 \mathrm{~W}-5 \\
(\mathrm{BG})\end{array}$ & $277^{\dagger}$ & $0.93^{\ddagger}$ & 202 & 3.7 & 16.3 & 7.5 & 12.8 & 9.7 & 10.5 \\
\hline $\begin{array}{l}99 \mathrm{~W}-6 \\
\text { (4) }\end{array}$ & 222 & 0.73 & 1083 & 4.0 & 16.4 & & & & \\
\hline $\begin{array}{l}99 \mathrm{~W}-7 \\
(14)\end{array}$ & 273 & 0.89 & 779 & 4.0 & 16.4 & 6.7 & 13.6 & & \\
\hline $\begin{array}{l}99 \mathrm{~W}-8 \\
\text { (BG) }\end{array}$ & 273 & 0.89 & 217 & 4.0 & 16.4 & 6.7 & 13.6 & 9.4 & 11.5 \\
\hline $\begin{array}{l}99 \mathrm{~W}-9 \\
(4)\end{array}$ & 224 & 0.72 & 1092 & 3.3 & 16.0 & & & & \\
\hline $\begin{array}{l}99 \mathrm{~W}-10 \\
\text { (4) }\end{array}$ & 224 & 0.72 & 1092 & 3.3 & 16.0 & & & & \\
\hline $\begin{array}{l}99 \mathrm{~W}-11 \\
(14)\end{array}$ & 274 & 0.88 & 756 & 3.3 & 16.0 & 6.9 & 13.4 & & \\
\hline $\begin{array}{l}99 \mathrm{~W}-12 \\
\text { (BG) }\end{array}$ & 274 & 0.88 & 200 & 3.3 & 16.0 & 6.9 & 13.4 & 8.0 & 11.9 \\
\hline
\end{tabular}

${ }^{*} \mathrm{BG}=$ baghouse inlet sampling port

${ }^{\dagger}$ Combustion rate for BG samples is assumed to equal rate at Port 14.

BG sampling rate is set equal to Port 14 rate; this is not an isokinetic sample. 


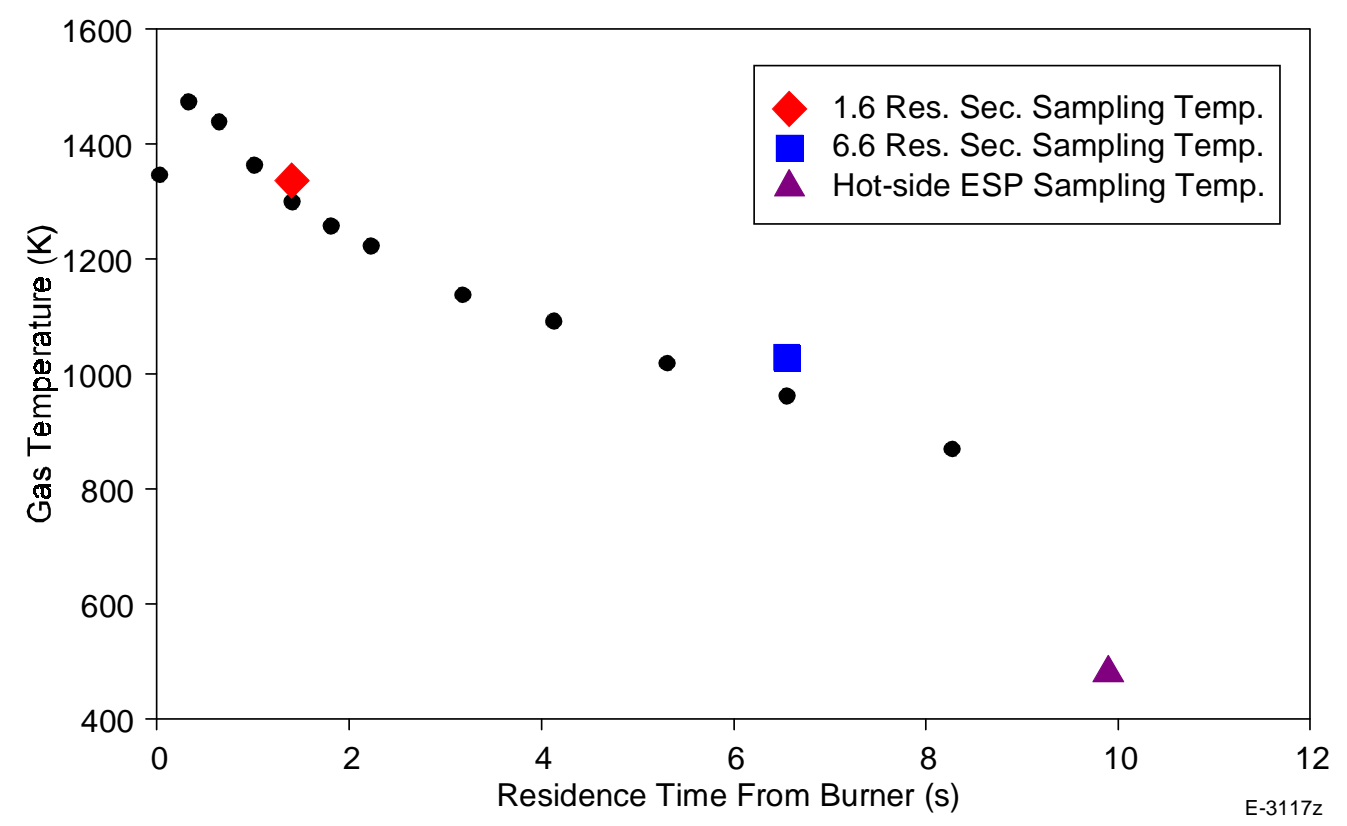

Figure 3-21. Typical self-evolving temperature profile for Wyodak coal combustion in the University of Arizona downflow combustor.

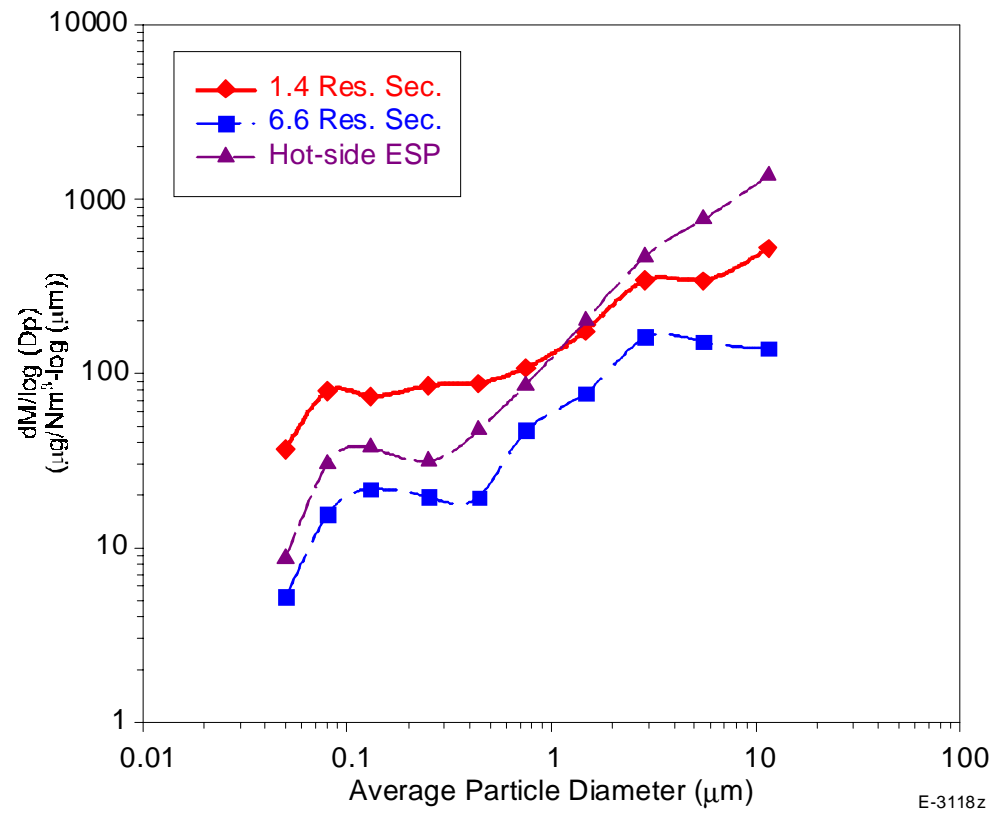

Figure 3-22. Typical particle size distributions for Wyodak fly ash at various residence times. 


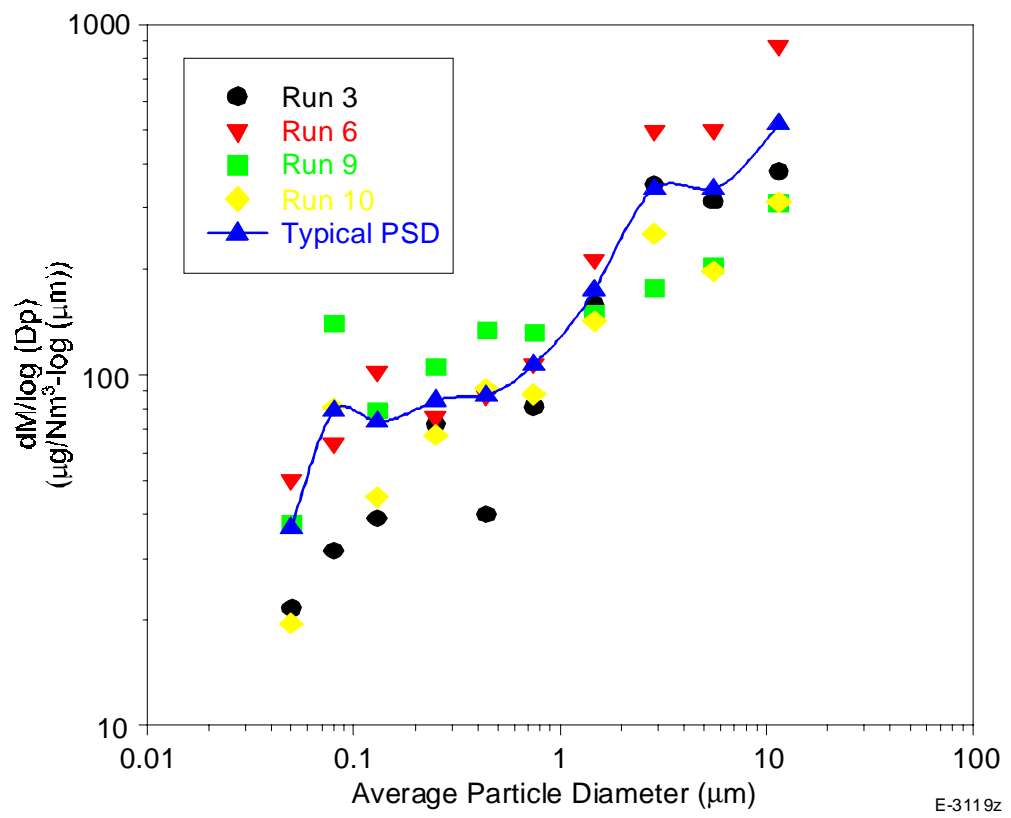

Figure 3-23. Particle size distribution data at 1.4 seconds for Wyodak fly ash.

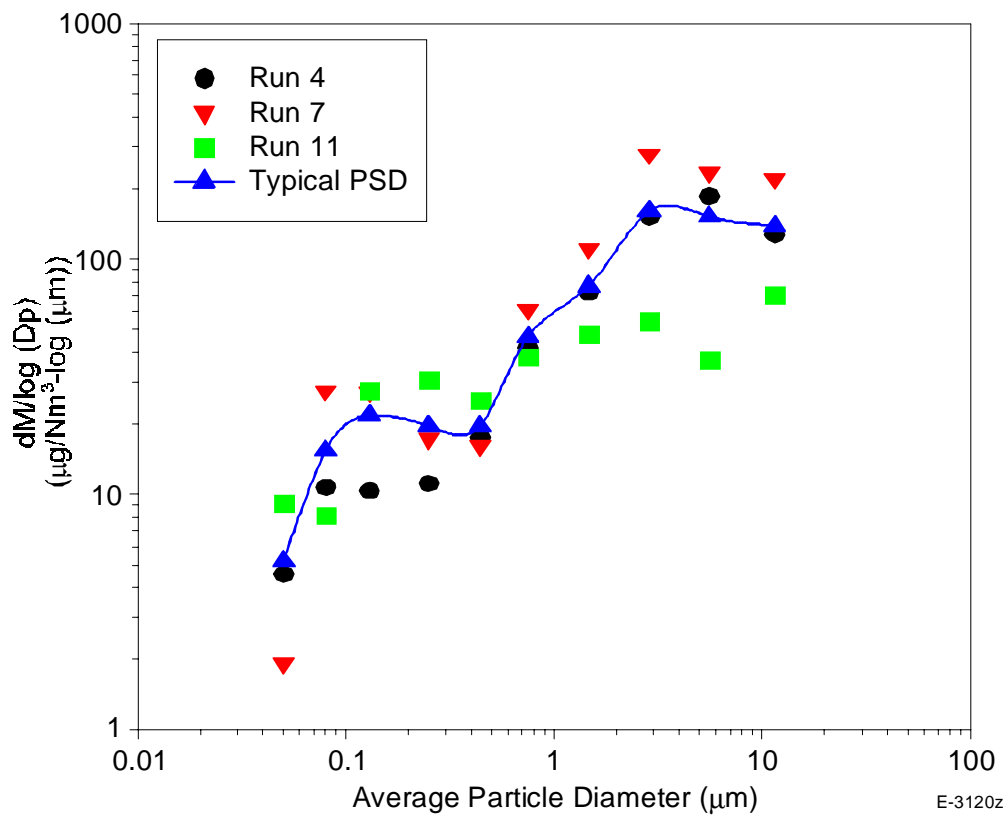

Figure 3-24. Particle size distribution data at 6.6 seconds for Wyodak fly ash. 


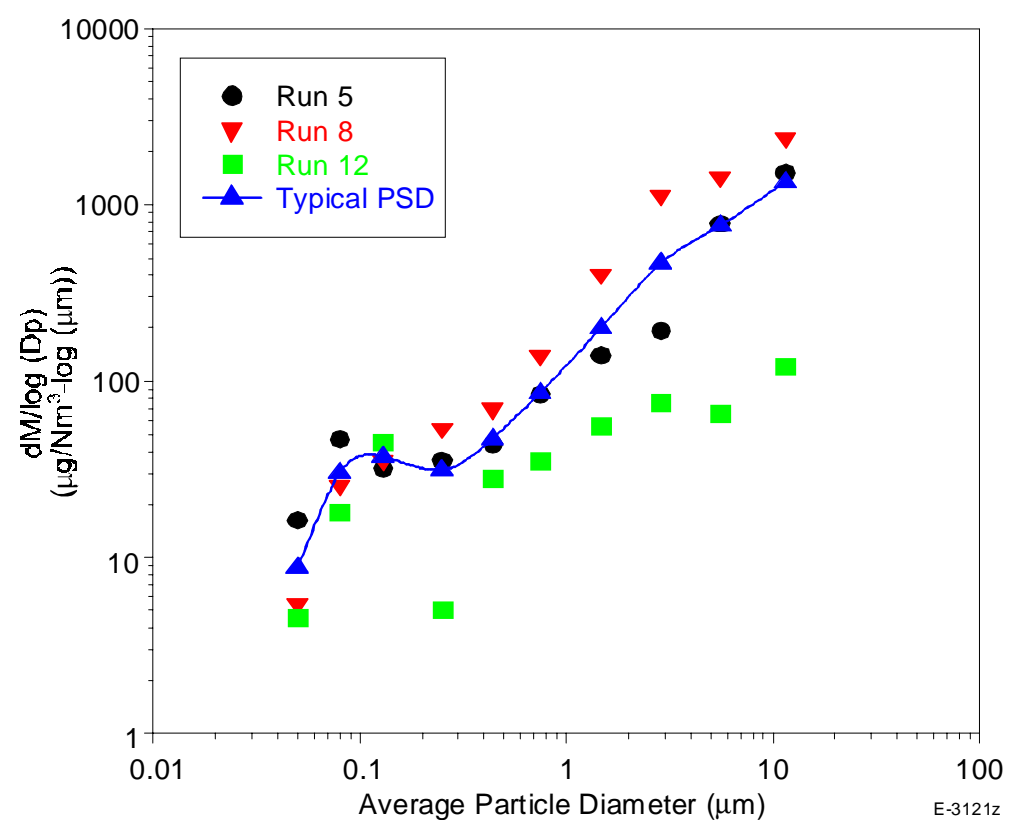

Figure 3-25. Particle size distribution data at hot-side ESP conditions for Wyodak fly ash.

pots in place, the sharper profile of the hot-side ESP PSD distribution indicates that growth to larger particles is significant between the 6.6 seconds and hot-side ESP sample locations.

\section{$\underline{\text { Elemental Analysis }}$}

Two representative sample sets from the 1.4 seconds sample location (sample runs 6 and 10), two representative sample sets from the 6.6 seconds sample location (sample runs 7 and 11) and three representative sample sets from the hot-side of the particulate collection device (sample runs 5, 8, and 12) were selected for analysis of size-segregated particle metal content at the University of Arizona by AA/GFAA. Appendix D, Tables D-1 to D-6, summarize the preliminary analytical results at each sampling location as analyzed by AAS and AES. Tables D-1 through D-3 document the major species concentrations at the three conditions. Tables D-4 to D-6 provide typical trace element concentrations for all elements analyzed by GFAA.

The typical concentration values from Tables D-1 to D-6 were used to generate individual element distribution profiles $^{1}$ for some of the more important trace elements (Figures 3-26 through 3-31). Cadmium results represent major outliers compared to the other results obtained and the information developed should be viewed with caution. We believe these results to be inaccurate. The $\mathrm{Cd}$ concentrations obtained from these experiments were abnormally high and are most likely the result of contamination from previous experiments conducted on this furnace involving cadmium. 


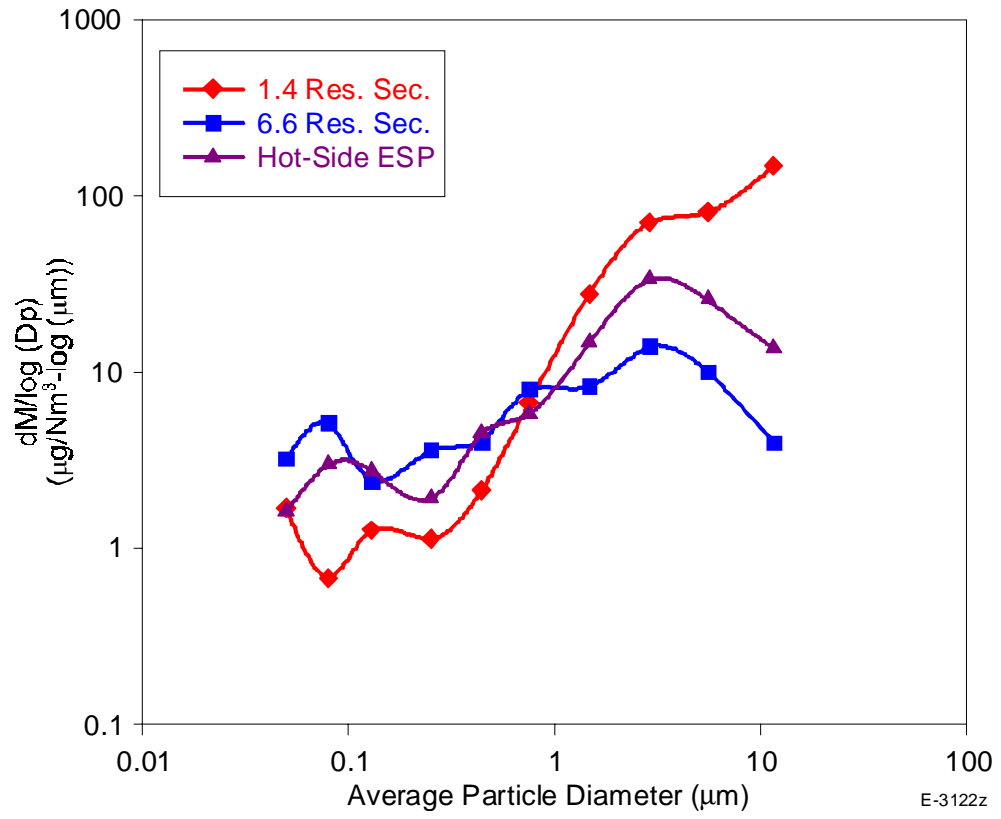

Figure 3-26. Typical arsenic distribution in Wyodak baseline fly ash at various residence times.

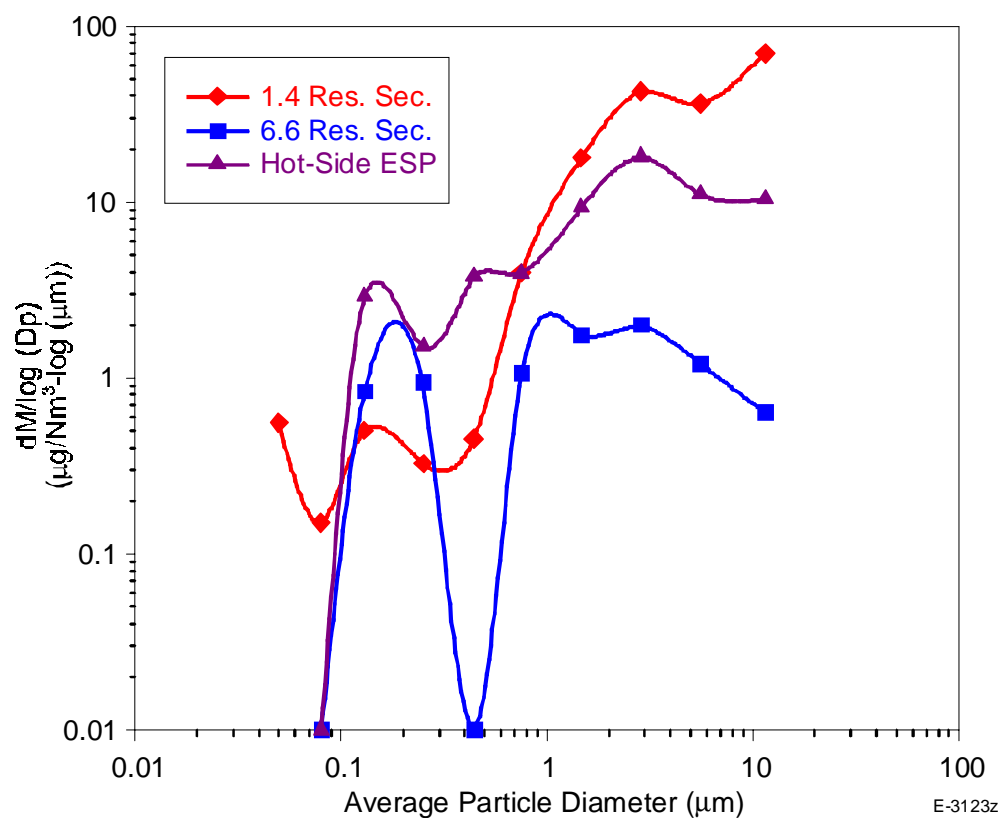

Figure 3-27. Typical selenium distribution in Wyodak baseline fly ash at various residence times $\left(0.01 \mathrm{dM} / \mathrm{d} \log \left(\mathrm{D}_{\mathrm{p}}\right)\right.$ values represent samples with selenium concentrations below the detection limit). 


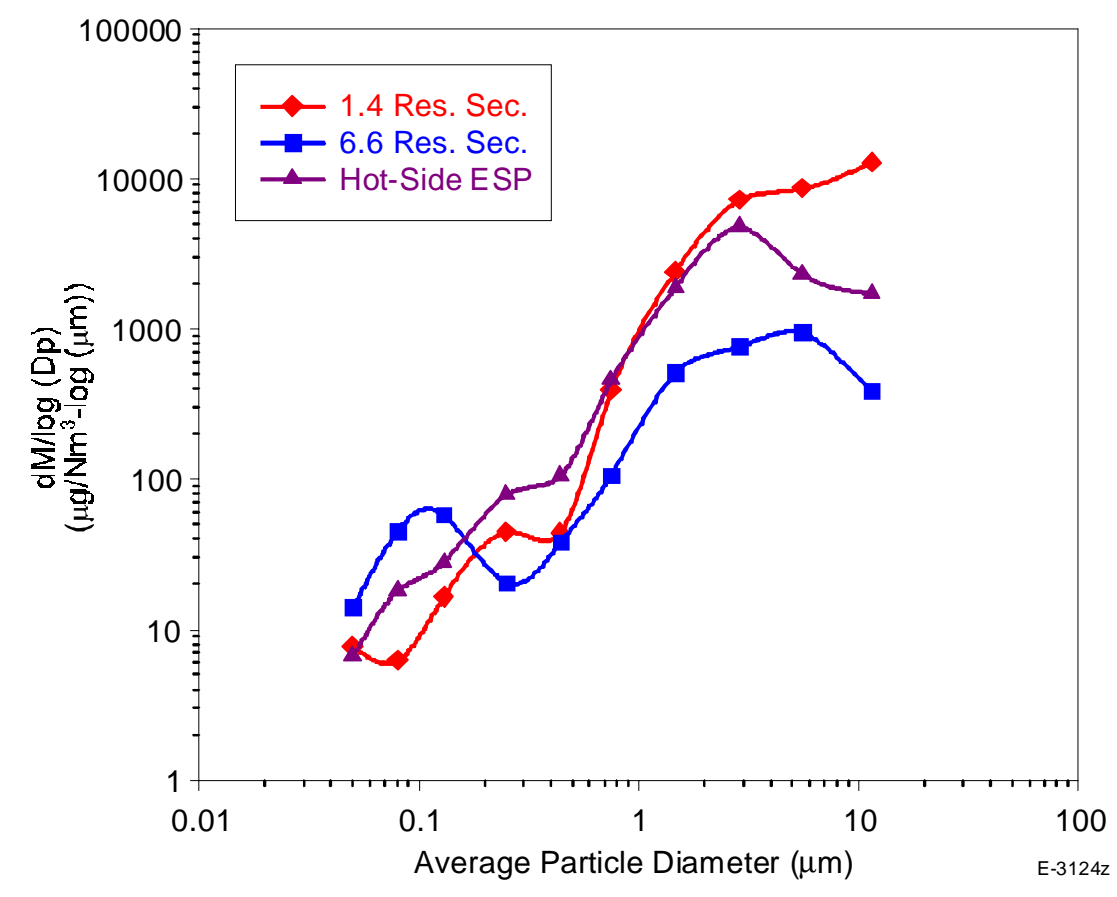

Figure 3-28. Typical cadmium distribution in Wyodak baseline fly ash at various residence times.

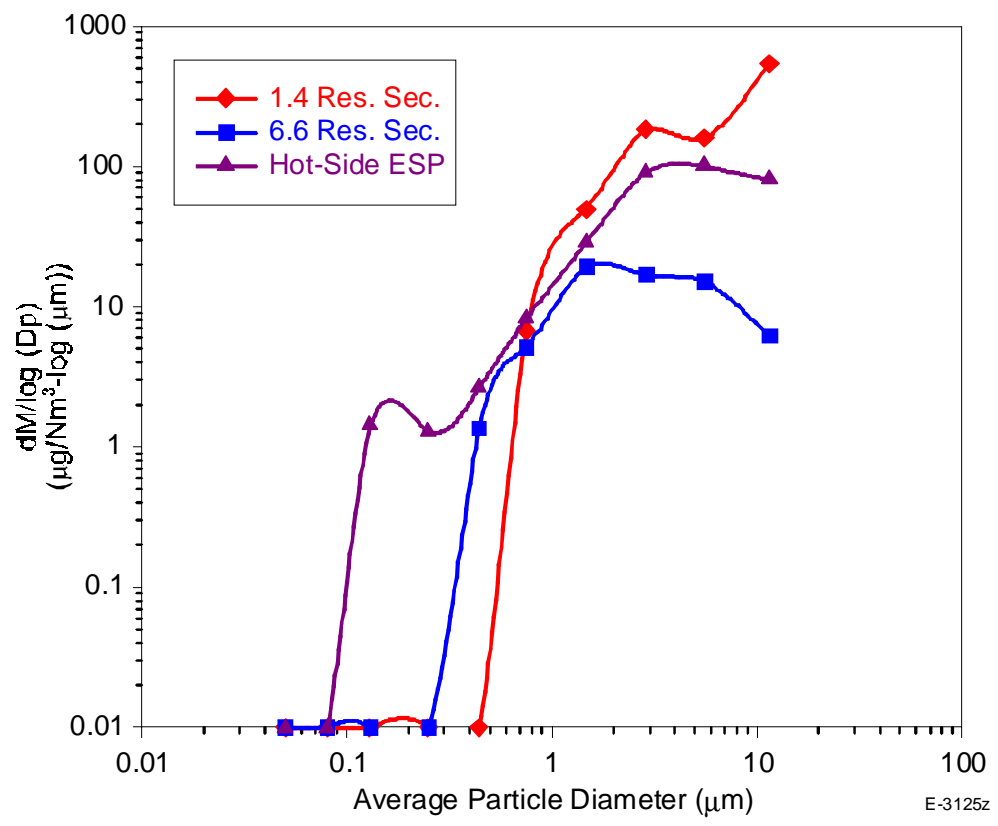

Figure 3-29. Typical cobalt distribution in Wyodak baseline fly ash at various residence times $\left(0.01 \mathrm{dM} / \mathrm{d} \log \left(\mathrm{D}_{\mathrm{p}}\right)\right.$ values represent samples with cobalt concentrations below the detection limit). 


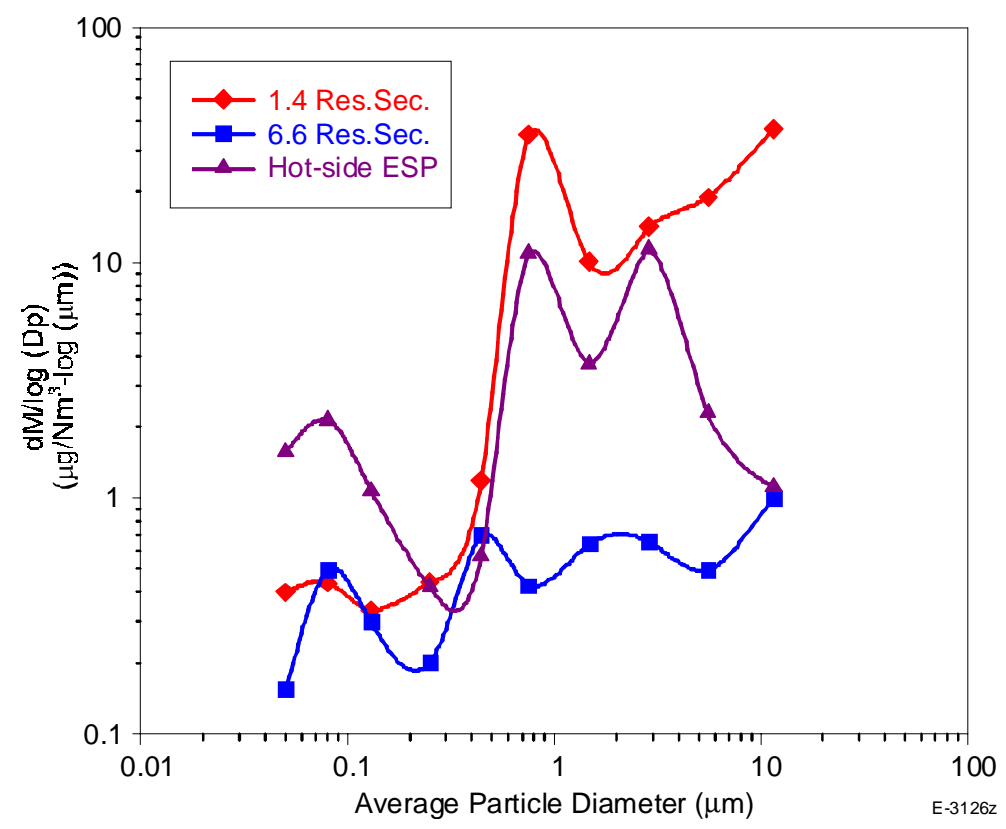

Figure 3-30. Typical antimony distribution in Wyodak baseline fly ash at various residence times.

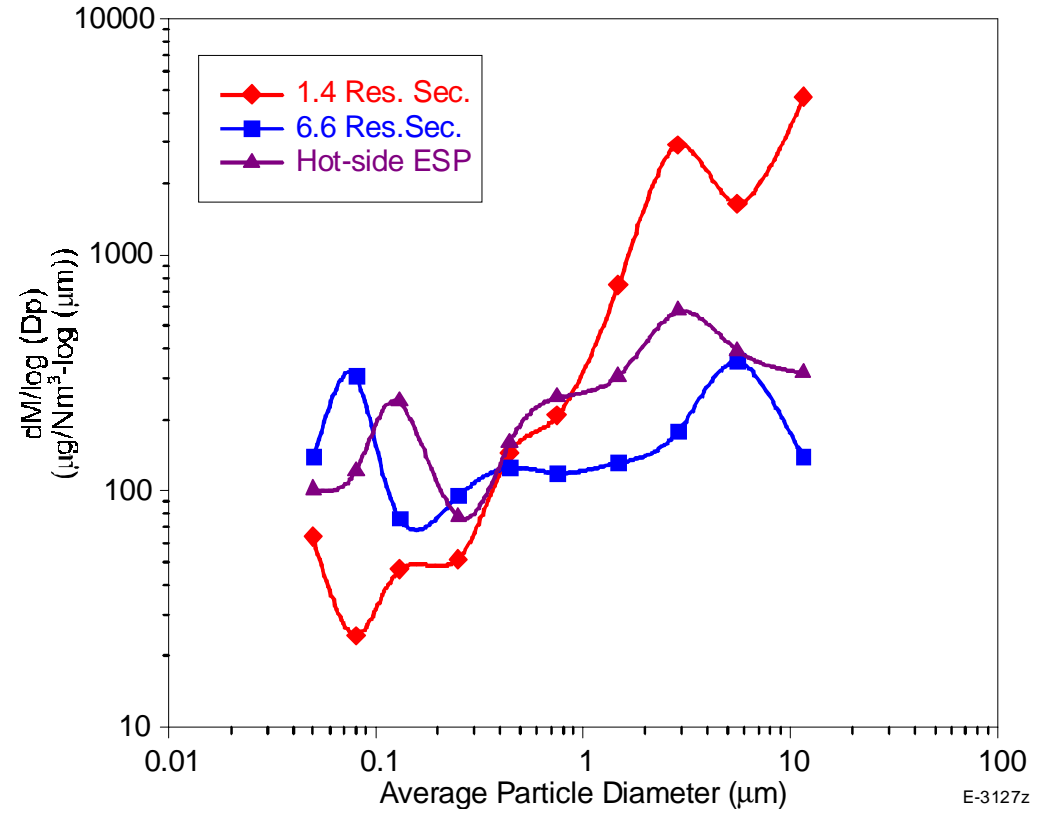

Figure 3-31. Typical chromium distribution in Wyodak baseline fly ash at various residence times. 


\section{$\underline{\text { Submicron Region }}$}

The submicron impactor stages represent a larger portion of the Wyodak ash (12 to 28\%) compared to the Ohio ash (less than 3\%). Of the major species analyzed, there is a fairly equal distribution of iron and calcium at 1.4 seconds with significant concentrations of silica and sodium also present. Chromium is the most significant of the trace elements analyzed.

Iron, calcium, and silicon represent most of the 6.6 seconds submicron fly ash in roughly equal proportions in the submicron region. $\mathrm{Cr}, \mathrm{Cd}$ (however $\mathrm{Cd}$ values are higher than expected due to contamination), and As are present in concentrations above $100 \mathrm{ppmw}$.

In order to compare the results at each sampling location, the PSDs can be normalized by calculating an enrichment factor, $\mathrm{E}_{\mathrm{fa}, \mathrm{x}}$, defined as the ratio of the ash mass collected on a given plate to the average ash mass collected over the entire impactor. ${ }^{2}$ Enrichment factors for the total fly ash, As, Se, Cd, Co, Sb, and $\mathrm{Cr}$ at all three sample conditions are listed in Table 3-7. This normalization removes the effect of sample conditions upon the mass concentrations.

Comparing $\mathrm{E}_{\mathrm{fa}, \mathrm{x}}$ at 6.6 seconds to $\mathrm{E}_{\mathrm{fa}, \mathrm{x}}$ at 1.4 seconds $\left(\mathrm{DE}_{\mathrm{f}, 6.6-1.4}\right)$ provides insight into partitioning behavior in the post-combustion zone. This comparison is shown in Figures 3-32 through 3-36 for As, $\mathrm{Se}, \mathrm{Co}, \mathrm{Sb}$, and $\mathrm{Cr}$, respectively. For comparison purposes, the $\mathrm{DE}_{\mathrm{f}, 2.2-0.5}$ values for the corresponding samples from Pittsburgh seam, Illinois No. 6, and Ohio 5/6/7 blend coal fly ash experiments are also included. A discussion of the $\mathrm{DE}_{\mathrm{f}, 2.2-0.5}$ results for these three coals is described earlier in this report. It should be noted that the residence time for the flue gas prior to sampling in the Wyodak experiments is longer than for the other three experiments (1.4 versus 0.5 seconds and 6.6 versus 2.2 seconds), although gas temperatures at the sampling locations are comparable.

The results in Figure 3-32 indicate that post-combustion vaporization of arsenic may be significant for the Wyodak coal. Positive submicron $\mathrm{DE}_{\mathrm{f}, 6.6-1.4}$ values indicate that heterogeneous transformation from the vapor phase to the surface of submicron particles is an important transformation mechanism for Wyodak arsenic.

Positive $\mathrm{DE}_{\mathrm{f}, 6.6-1.4}$ values in the <0.1 micron and 0.1-0.6 micron region of Figure 3-33 implies that post-combustion volatilization and subsequent heterogeneous transformation to the surface of submicron particles is also an important transformation mechanism for selenium during combustion of Wyodak coal.

Cobalt concentrations in the submicron region were below the GFAA detection limit. Thus, only supermicron $\mathrm{DE}_{\mathrm{f}, 6.6-1.4}$ values are shown in Figure 3-34.

The results in Figure 3-35 for antimony are similar to those in Figure 3-33 for selenium. Chromium results in Figure 3-36 are very similar to those for arsenic. In both cases volatilization and subsequent heterogeneous transformation to the surface of submicron particles appears to be an important transformation mechanism. 
Table 3-7. Preliminary Enrichment Factors $\left(\mathrm{E}_{\mathrm{f}}\right)$ for Wyodak fly ash sampled at 1.4 Seconds, 6.6 Seconds, and Hot-side ESP Conditions

\begin{tabular}{|c|c|c|c|c|c|c|c|c|c|c|c|}
\hline Aerodynamic Diameter (50\% Cutoff), microns & 0.03 & 0.06 & 0.09 & 0.17 & 0.34 & 0.54 & 0.98 & 1.98 & 3.77 & 7.33 & 15.7 \\
\hline \multicolumn{12}{|l|}{ 1.6 Seconds } \\
\hline Total Fly Ash & 0.20 & 0.24 & 0.36 & 0.49 & 0.33 & 0.53 & 1.01 & 1.84 & 1.86 & 3.26 & 0.87 \\
\hline Arsenic & 0.23 & 0.04 & 0.09 & 0.07 & 0.12 & 0.31 & 0.81 & 1.05 & 1.21 & 1.44 & 1.12 \\
\hline Selenium & 0.16 & 0.02 & 0.07 & 0.04 & 0.05 & 0.38 & 1.06 & 1.31 & 1.12 & 1.41 & 0.64 \\
\hline Cadmium & 0.01 & & 0.01 & 0.03 & 0.03 & 0.23 & 0.85 & 1.31 & 1.57 & 1.53 & 0.61 \\
\hline Cobalt & & & & & & 0.12 & 0.54 & 1.04 & 0.90 & 2.00 & 0.34 \\
\hline Antimony & 0.17 & 0.08 & 0.07 & 0.08 & 0.21 & 4.94 & 0.87 & 0.63 & 0.84 & 1.07 & 1.26 \\
\hline Chromium & 0.28 & 0.05 & 0.10 & 0.10 & 0.27 & 0.31 & 0.69 & 1.38 & 0.78 & 1.44 & 1.37 \\
\hline \multicolumn{12}{|l|}{6.6 Seconds } \\
\hline Total Fly Ash & 0.08 & 0.13 & 0.30 & 0.31 & 0.21 & 0.65 & 1.24 & 2.42 & 2.32 & 2.44 & 0.89 \\
\hline Arsenic & 7.10 & 3.83 & 1.28 & 2.12 & 2.38 & 1.95 & 1.25 & 1.01 & 0.76 & 0.33 & 0.60 \\
\hline Selenium & & & 3.29 & 4.07 & & 1.95 & 1.94 & 1.05 & 0.68 & 0.39 & \\
\hline Cadmium & 0.78 & 0.84 & 0.78 & 0.30 & 0.57 & 0.66 & 1.93 & 1.39 & 1.83 & 0.81 & 0.41 \\
\hline Cobalt & & & & & 0.74 & 1.15 & 2.67 & 1.12 & 1.07 & 0.47 & 0.50 \\
\hline Antimony & 3.73 & 4.04 & 1.75 & 1.30 & 4.55 & 1.15 & 1.06 & 0.52 & 0.42 & 0.91 & 2.01 \\
\hline Chromium & 12.24 & 9.14 & 1.62 & 2.23 & 2.94 & 1.16 & 0.79 & 0.51 & 1.08 & 0.46 & 0.44 \\
\hline \multicolumn{12}{|l|}{ Hot-side ESP Conditions } \\
\hline Total Fly Ash & 0.03 & 0.06 & 0.11 & 0.11 & 0.11 & 0.25 & 0.69 & 1.50 & 2.51 & 5.08 & 0.55 \\
\hline Arsenic & 5.59 & 2.98 & 2.23 & 1.84 & 2.88 & 2.04 & 2.20 & 2.19 & 1.01 & 0.31 & 0.89 \\
\hline Selenium & & & 4.10 & 2.51 & 4.23 & 2.41 & 2.43 & 2.04 & 0.76 & 0.40 & 0.94 \\
\hline Cadmium & 0.25 & 0.20 & 0.25 & 0.84 & 0.74 & 1.76 & 3.13 & 3.38 & 1.01 & 0.42 & 1.02 \\
\hline Cobalt & & & 0.38 & 0.41 & 0.56 & 0.95 & 1.41 & 1.93 & 1.31 & 0.60 & 0.74 \\
\hline Antimony & 17.43 & 6.90 & 2.79 & 1.30 & 1.16 & 12.38 & 1.80 & 2.36 & 0.29 & 0.08 & 0.83 \\
\hline Chromium & 14.61 & 5.05 & 8.07 & 3.09 & 4.28 & 3.64 & 1.93 & 1.57 & 0.65 & 0.29 & 1.60 \\
\hline
\end{tabular}




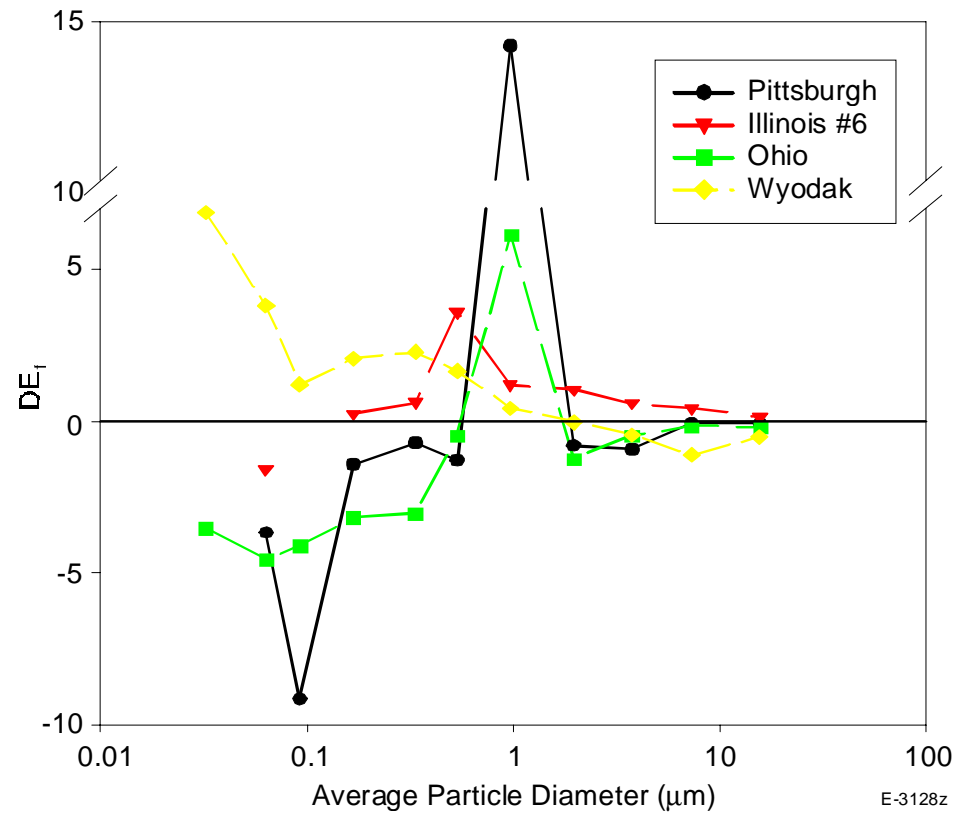

Figure 3-32. Arsenic differential enrichment factor comparison, $\mathrm{DE}_{\mathrm{f}}\left(\mathrm{E}_{\mathrm{f}, 2.2}-\mathrm{E}_{\mathrm{f}, 0.5}\right)$ for Pittsburgh, Illinois No. 6, and Ohio; $\mathrm{DE}_{\mathrm{f}}\left(\mathrm{E}_{\mathrm{f}, 6.6}-\mathrm{E}_{\mathrm{f}, 1.4}\right)$ for Wyodak.

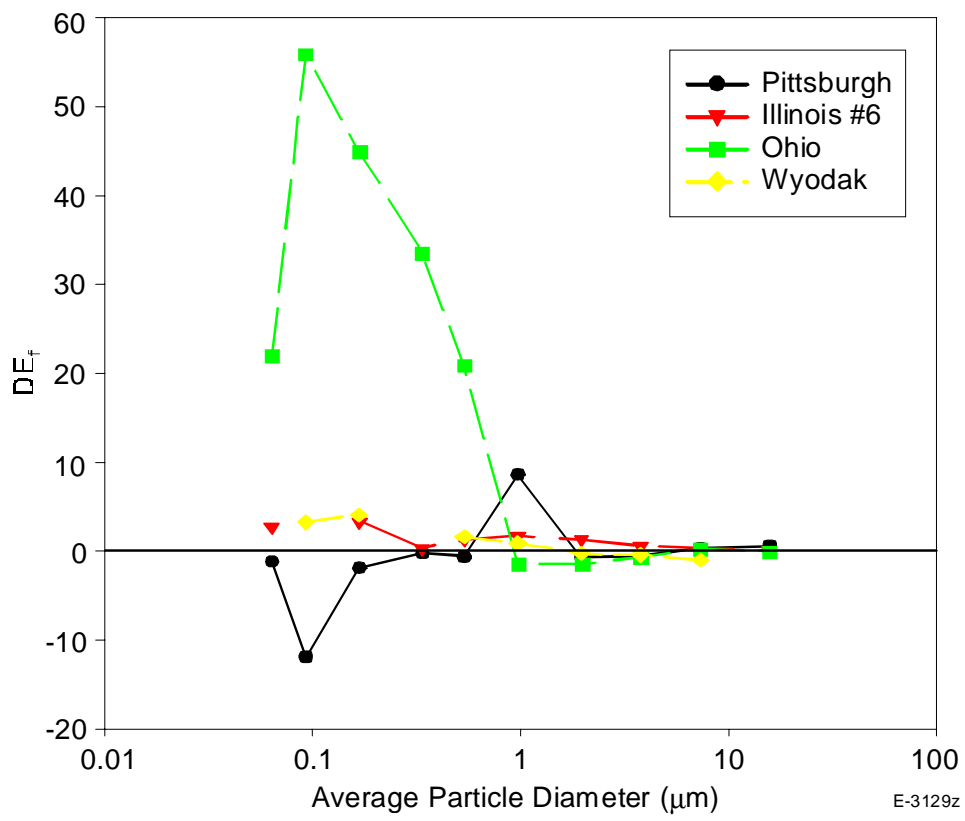

Figure 3-33. Selenium differential enrichment factor comparison, $\mathrm{DE}_{\mathrm{f}}\left(\mathrm{E}_{\mathrm{f}, 2.2}-\mathrm{E}_{\mathrm{f}, 0.5}\right)$ for Pittsburgh, Illinois No. 6, and Ohio; $\mathrm{DE}_{\mathrm{f}}\left(\mathrm{E}_{\mathrm{f}, 6.6}-\mathrm{E}_{\mathrm{f}, 1.4}\right)$ for Wyodak. 


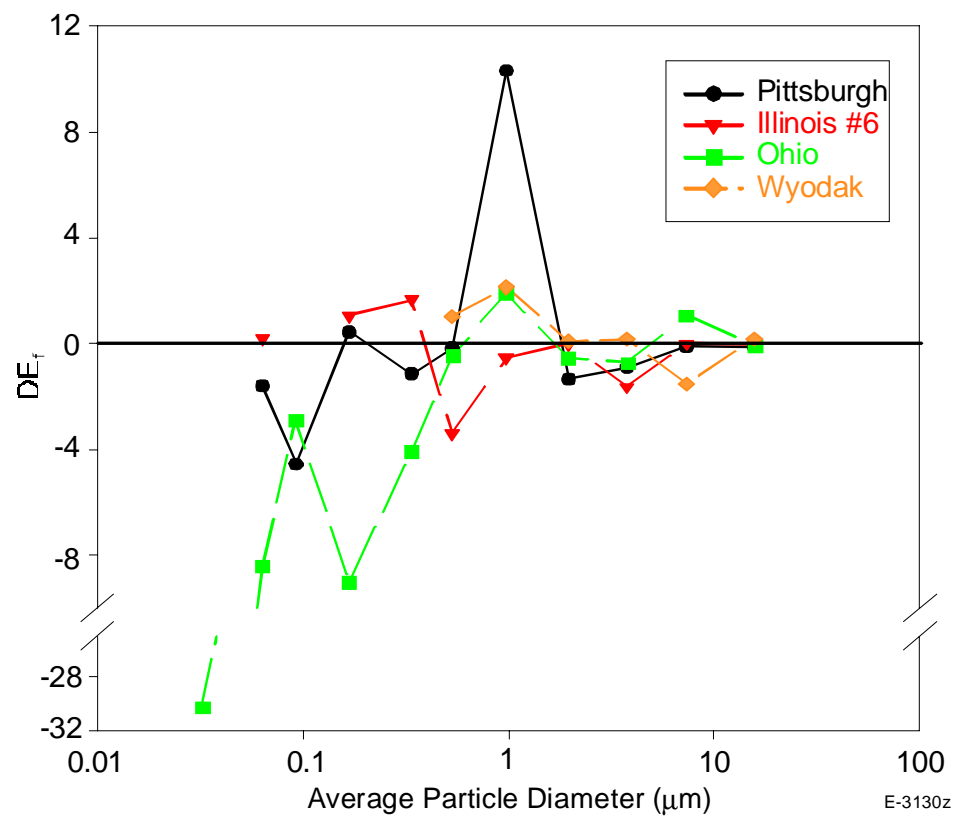

Figure 3-34. Cobalt differential enrichment factor comparison, $\mathrm{DE}_{\mathrm{f}}\left(\mathrm{E}_{\mathrm{f}, 2.2}-\mathrm{E}_{\mathrm{f}, 0.5}\right)$ for Pittsburgh, Illinois No. 6, and Ohio; $\mathrm{DE}_{\mathrm{f}}\left(\mathrm{E}_{\mathrm{f}, 6.6}-\mathrm{E}_{\mathrm{f}, 1.4}\right)$ for Wyodak.

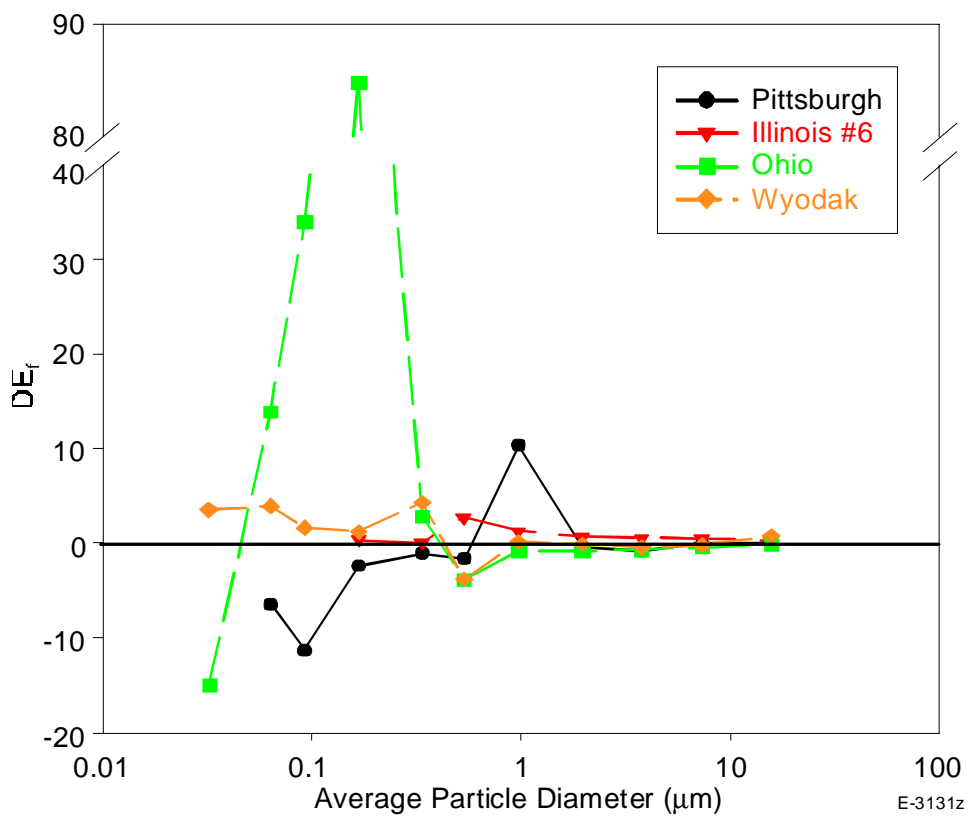

Figure 3-35. Antimony differential enrichment factor comparison, $\mathrm{DE}_{\mathrm{f}}\left(\mathrm{E}_{\mathrm{f}, 2.2}-\mathrm{E}_{\mathrm{f}, 0.5}\right)$ for Pittsburgh, Illinois No. 6, and Ohio; $\mathrm{DE}_{\mathrm{f}}\left(\mathrm{E}_{\mathrm{f}, 6.6}-\mathrm{E}_{\mathrm{f}, 1.4}\right)$ for Wyodak. 


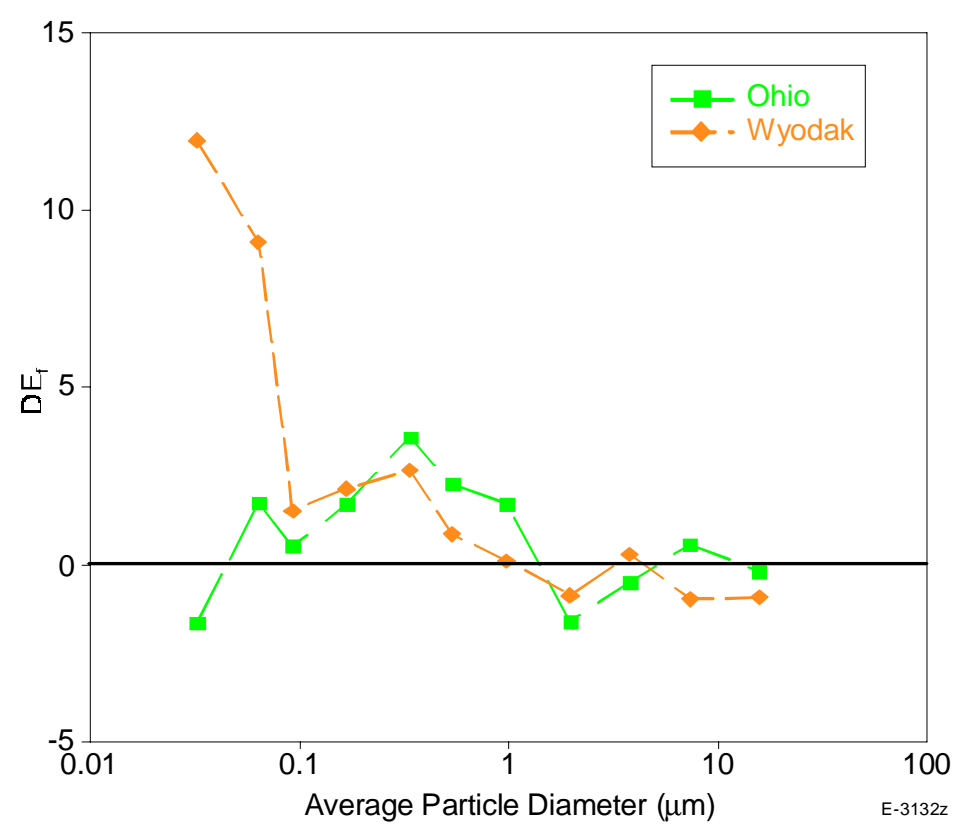

Figure 3-36. Chromium differential enrichment factor comparison, $\mathrm{DE}_{\mathrm{f}}\left(\mathrm{E}_{\mathrm{f}, 2.2}-\mathrm{E}_{\mathrm{f}, 0.5}\right)$ for Ohio; $\mathrm{DE}_{\mathrm{f}}\left(\mathrm{E}_{\mathrm{f}, 6.6}-\mathrm{E}_{\mathrm{f}, 1.4}\right)$ for Wyodak.

\section{$\underline{\text { Supermicron Region }}$}

Log-log plots of trace metal concentration versus particle size in the 6.6 seconds samples can provide some insight into these heterogeneous partitioning mechanisms. A $1 / \mathrm{d}_{\mathrm{p}}$ (particle diameter) dependence indicates that, in the continuum regime, exterior surface reaction or pore diffusion controlled surface reaction may be the dominant formation mechanism. $1 / \mathrm{d}_{\mathrm{p}}{ }^{2}$ dependence indicates that gas film transfer is the controlling rate process; which is true for condensation in the continuum regime or for infinitely fast surface reaction. ${ }^{3}$ The results are shown in Figure 3-37 for As, Se, Cd, Co, Sb, and Cr from Wyodak coal fly ash sampled at 6.6 seconds. No dependence on particle size is observed for $\mathrm{Sb}$ or $\mathrm{Cr}$. There appears to be a $1 / \mathrm{d}_{\mathrm{p}}$ dependence for $\mathrm{As}, \mathrm{Se}, \mathrm{Cd}$ (however all $\mathrm{Cd}$ results are suspect due to contamination in the furnace from previous experiments), and Co. As with previous experimental results, the $1 / \mathrm{d}_{\mathrm{p}}$ dependence correlation is most obvious in selenium.

The Phase I results suggested that metal-calcium complexes may be an important mechanism for the heterogeneous transformation of semi-volatile trace elements in the supermicron region. To explore the potential of metal-calcium reactions in the supermicron region as an important partitioning mechanism, the concentration of metal from a specific impactor stage (stages with a 50\% cutoff diameter of 0.97 microns or greater) was plotted versus the corresponding calcium concentration. If metal-calcium reactions are important, there should 


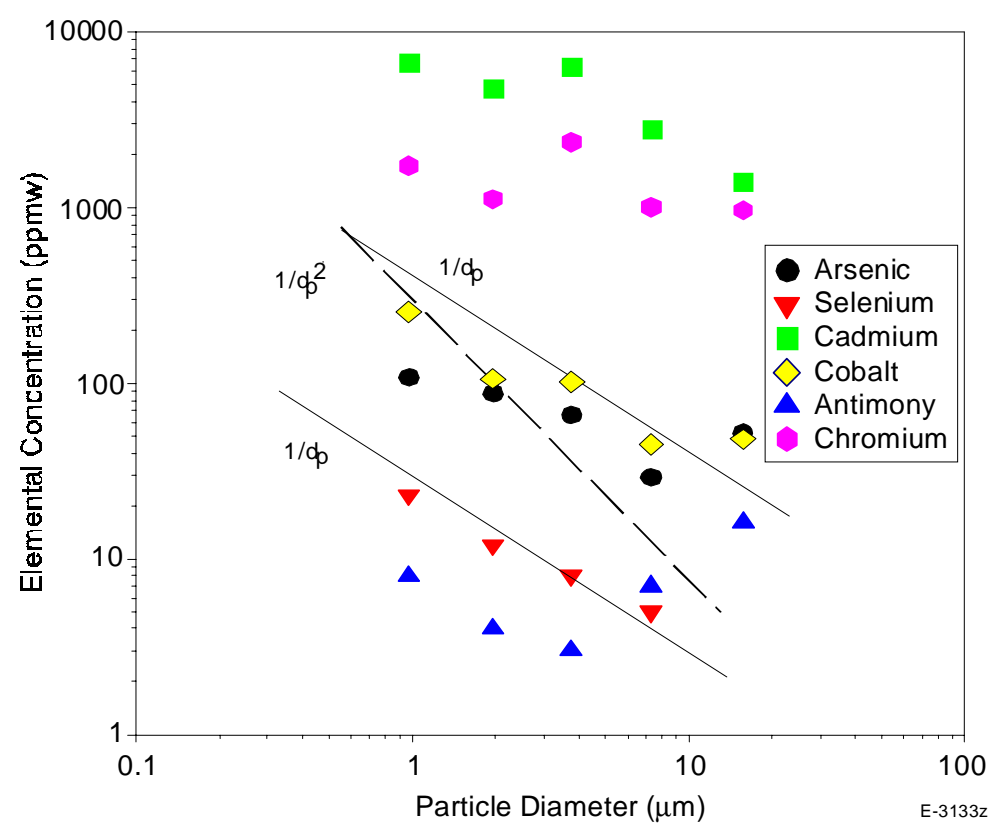

Figure 3-37. Particle size dependence of $\mathrm{As}, \mathrm{Se}, \mathrm{Cd}, \mathrm{Co}, \mathrm{Sb}$, and $\mathrm{Cr}$ sampled at 6.6 seconds from combustion of Wyodak Coal

be a correlation between the metal concentration and calcium concentration for those impactor stages having a relatively low $\mathrm{Ca}$ concentration. One expects the data to deviate from the correlation at higher $\mathrm{Ca}$ concentrations since an excess of unbound $\mathrm{Ca}$ is likely to be present. The results are shown in Figures 3-38 through 3-43 for $\mathrm{As}, \mathrm{Se}, \mathrm{Cd}, \mathrm{Co}, \mathrm{Sb}$, and $\mathrm{Cr}$, respectively.

In Figure 3-38 the concentration of As on a given stage is plotted versus the corresponding $\mathrm{Ca}$ concentration for the Wyodak fly ash at all three sampling conditions. There appears to be an As-Ca correlation for the 6.6 seconds condition. This correlation implies that As-Ca complexation is important in the heterogeneous transformation of arsenic to supermicron particles in the post-combustion zone during the combustion of Wyodak coal.

The concentration of Se on a given stage is plotted versus the corresponding $\mathrm{Ca}$ concentration for the Wyodak test runs in Figure 3-39. The results indicate that there may be a Se-Ca correlation for the 6.6 seconds condition. It is important to note that there does not appear to be an Se-Ca correlation at the 1.4 seconds condition. This is different from the other three coals we have examined - all of which appear to have Se-Ca complexation occurring prior to 0.5 seconds. It will be interesting to see if the form of occurrence of Se in the coal can be used to explain this result.

Cadmium versus calcium is plotted in Figure 3-40. Due to the contamination of $\mathrm{Cd}$ in the test samples, we hesitate to draw any conclusions from these data. 


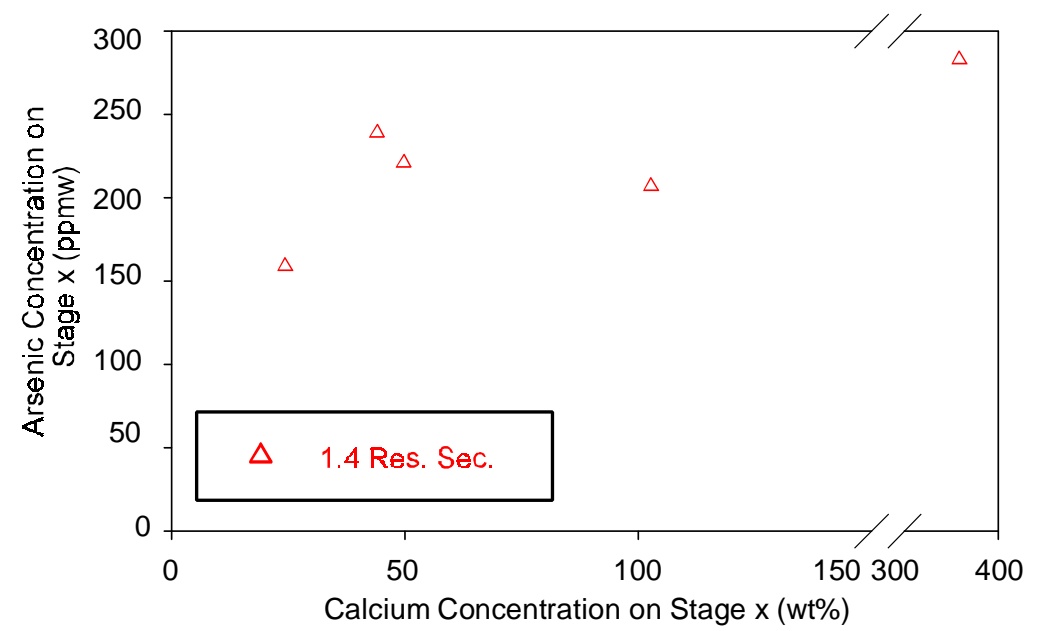

(a)

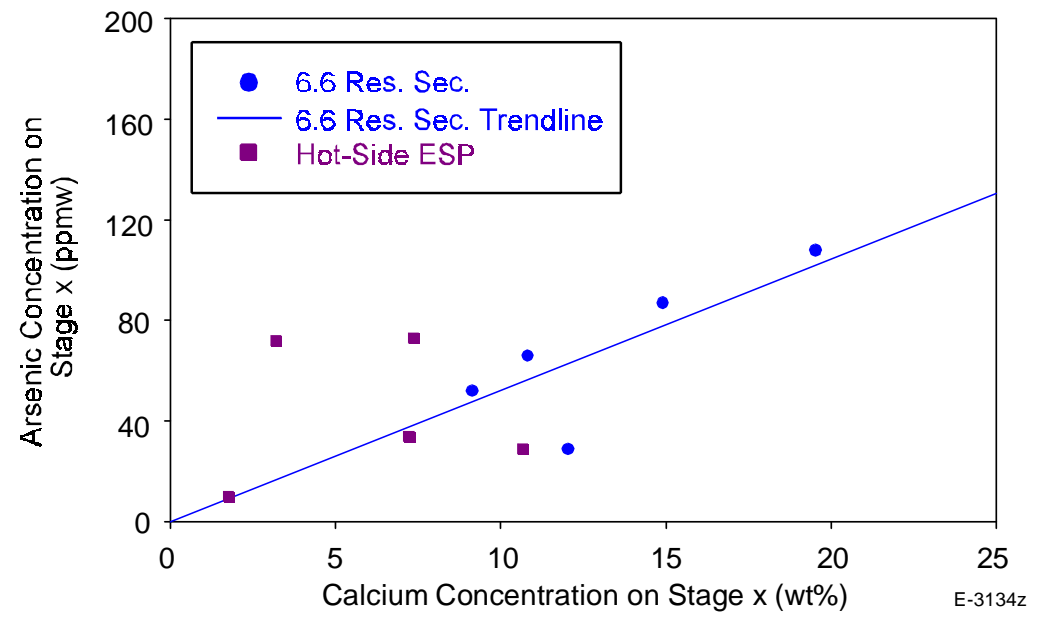

(b)

Figure 3-38. Arsenic-calcium correlation for Wyodak fly ash a) 1.4 seconds and b) 6.6 seconds and hot-side ESP conditions.

The cobalt versus calcium plot in Figure 3-41 is interesting. There appears to be a correlation at the 1.4 seconds condition but not at the 6.6 seconds or hot-side ESP conditions. We have not found evidence of Co-Ca complexation reported in the literature and would not expect to see any correlation in the data. Further study is required to determine if the apparent correlation shown in Figure 3-41a is real.

The correlation of antimony to calcium in the supermicron particles of Wyodak fly ash is shown in Figure 3-42. There appears to be a correlation at the 6.6 seconds condition. This implies that $\mathrm{Sb}-\mathrm{Ca}$ complexation may be an important mechanism in the post-combustion phase transformation of this element.

No correlation was observed between chromium and calcium (see Figure 3-43). 


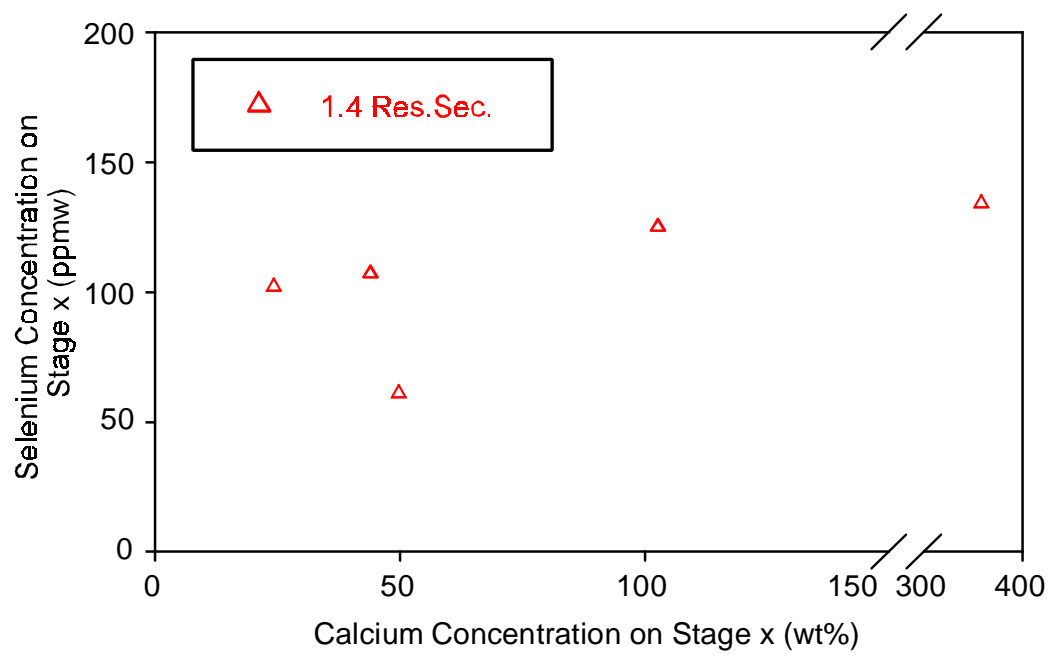

(a)

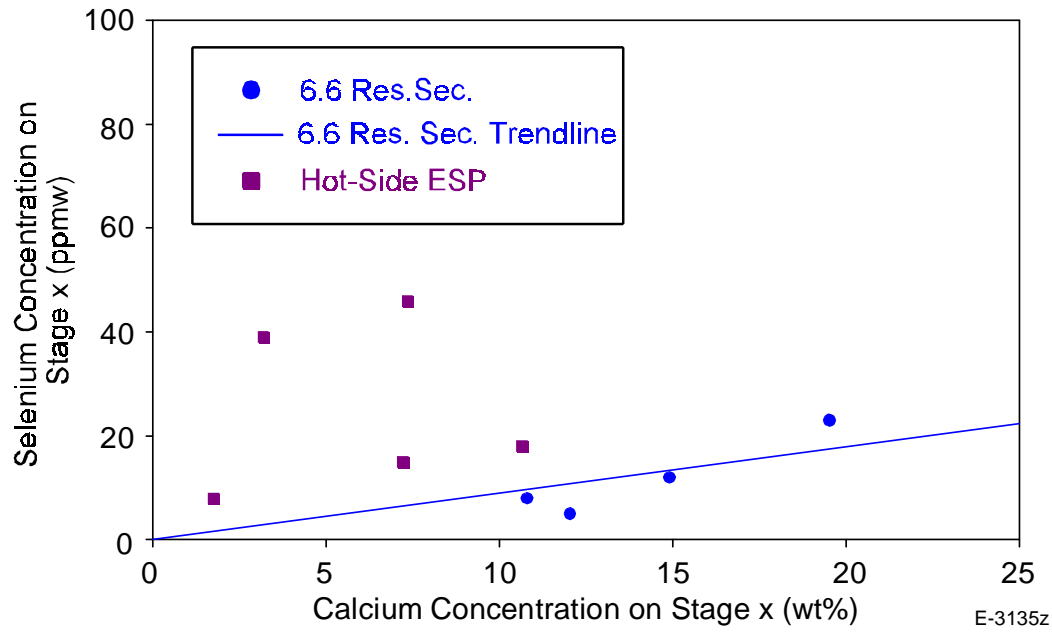

(b)

Figure 3-39. Selenium-calcium correlation for Wyodak fly ash a) 1.4 seconds and b) 6.6 seconds and hot-side ESP conditions.

\subsubsection{Baseline Studies of Illinois No.6 Coal}

The University of Arizona's pilot-scale downflow laboratory combustion furnace was used to test the partitioning of toxic metals in baseline experiments for the Illinois No. 6 bituminous coal at hot-side ESP conditions.

Sample collection media for the BLPI consisted of polycarbonate membranes sprayed with a high purity grease. The membranes were dried in a vacuum dessicator for a minimum of 24 hours. $1.5 \mathrm{ml} \mathrm{PVC} \mathrm{sample} \mathrm{vials} \mathrm{were} \mathrm{used} \mathrm{to} \mathrm{contain} \mathrm{the} \mathrm{particulate-laden} \mathrm{membranes.} \mathrm{The} \mathrm{vials}$ were weighed with and without the particulate-laden membranes on a microbalance and 


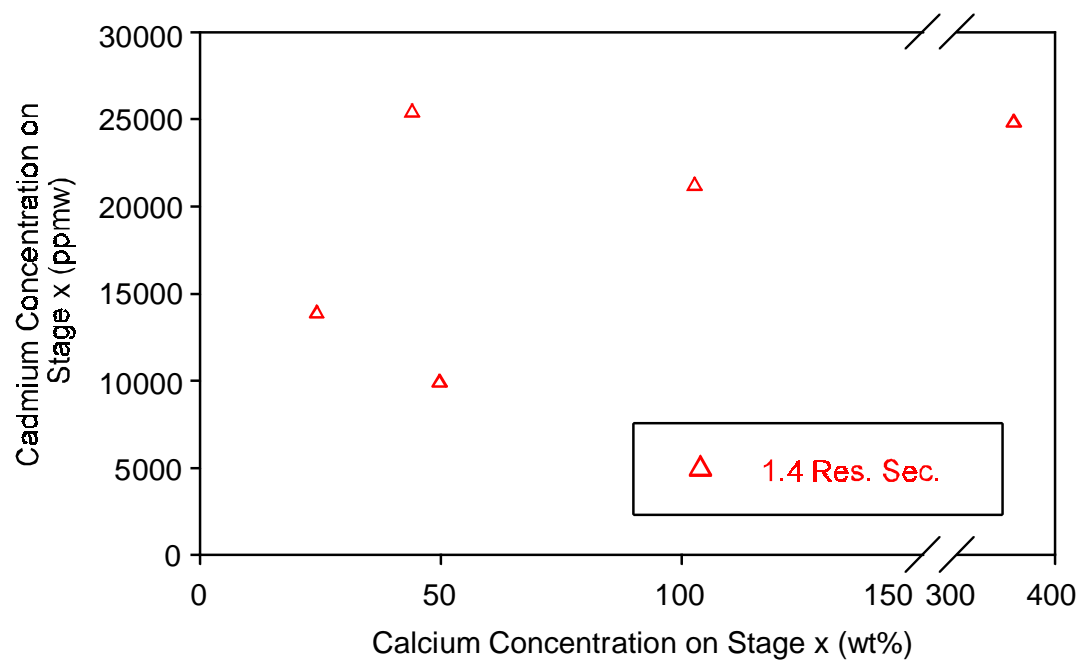

(a)

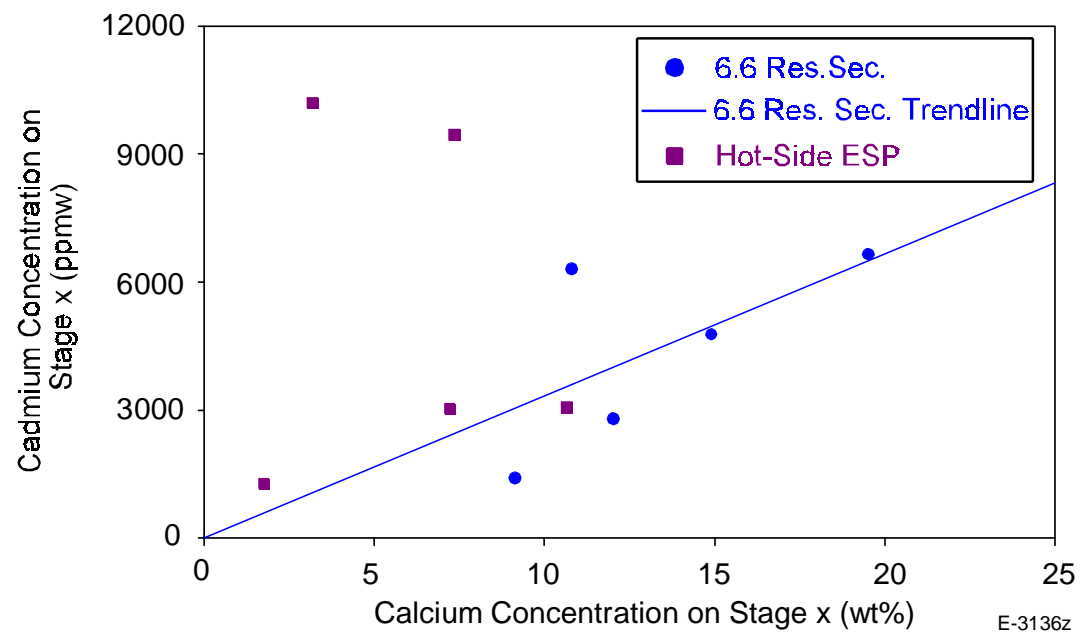

(b)

Figure 3-40. Cadmium-calcium correlation for Wyodak fly ash a) 1.4 seconds and b) 6.6 seconds and hot-side ESP conditions.

stored in zip-loc sealed polyethylene bags. The dried sample media were also weighed on the microbalance just prior to loading into the BLPI. All microbalance weights were repeated. Two readings with a deviation of less than $0.00003 \mathrm{~g}$ were required before the weight data were accepted as accurate.

Particulate samples were collected during one test run. Both experiments were performed at a coal feed rate of $2.2 \mathrm{~kg} / \mathrm{hr}$. Two sample sets were taken from the inlet to the baghouse and represent hot-side ESP sampling conditions. The baghouse samples are taken after partial segregation of large particles in an ash trap and a small particle trap.

We found that a single collection test, performed without the BLPI inlet cyclone, could be used to collect both size-segregated samples from the BLPI. The sample sets and test runs are 


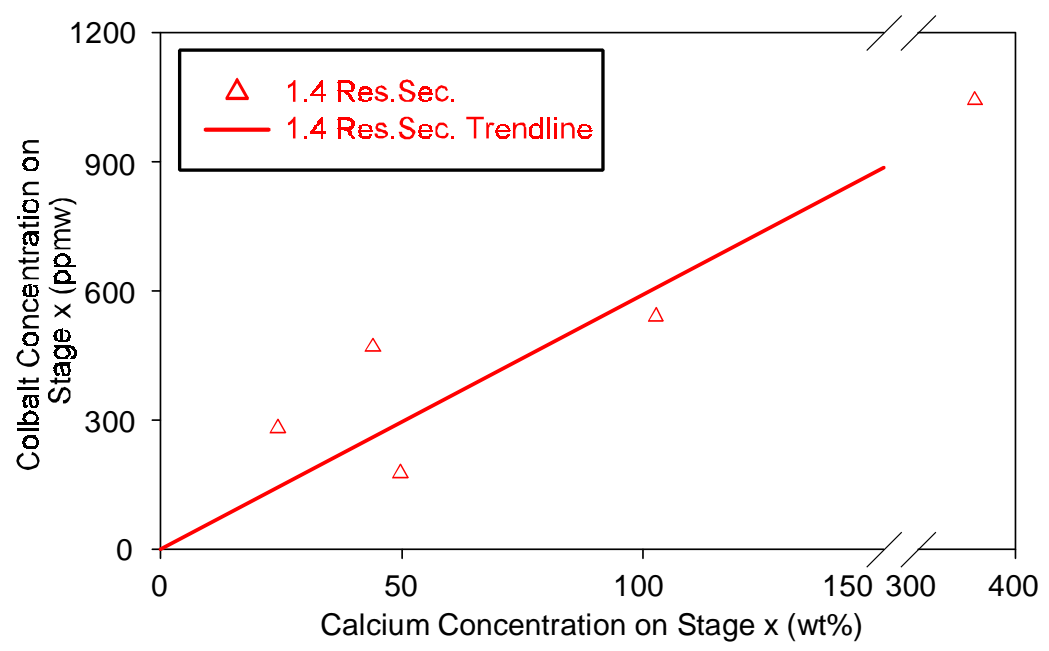

(a)

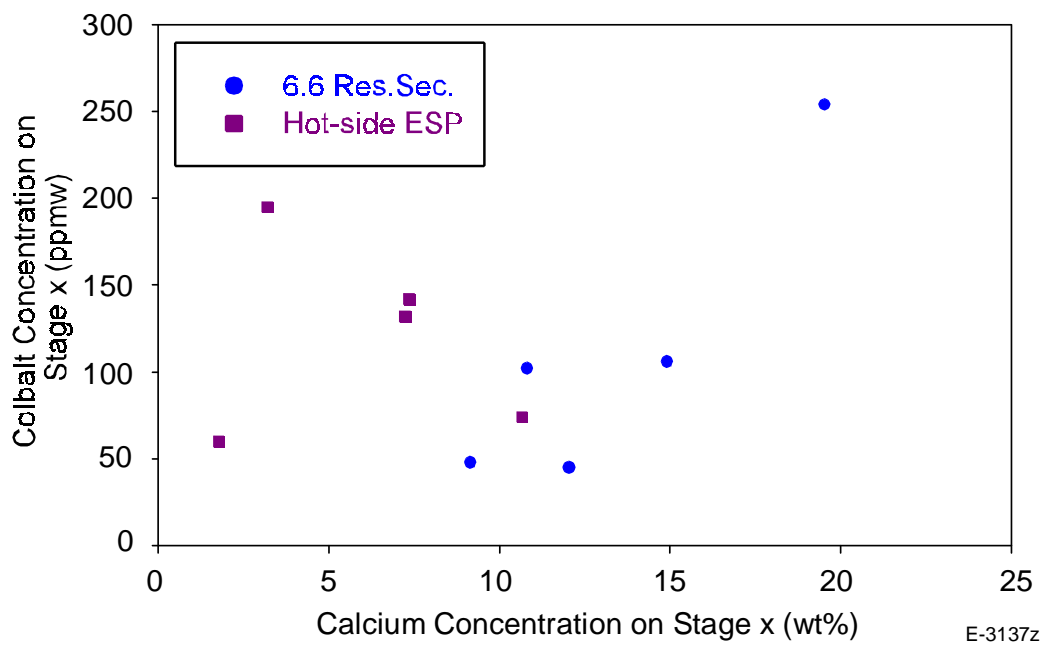

(b)

Figure 3-41. Cobalt-calcium correlation for Wyodak fly ash a) 1.4 seconds and b) 6.6 seconds and hot-side ESP conditions.

summarized in Table 3-8. Table 3-9 shows the sampling conditions for the most important sample sets. A typical steady-state temperature profile for a $2.2 \mathrm{~kg} / \mathrm{hr}$ feed rate of Illinois No. 6 in the Univ. of Arizona downflow combustor is provided in the Phase I Final Report.

\section{$\underline{\text { Particle Size Distribution }}$}

Using the size-segregated ash weights collected in the BLPI in each test, a typical particle size distribution (PSD) was determined following the method described by Markowski and Ensor. ${ }^{1}$ This PSD is shown in Figure 3-44. It should be noted that the large-size particle distribution for these Hot-Side ESP samples are artificially depressed because some of the largesize particles drop out of the gas phase prior to this sample collection point. 


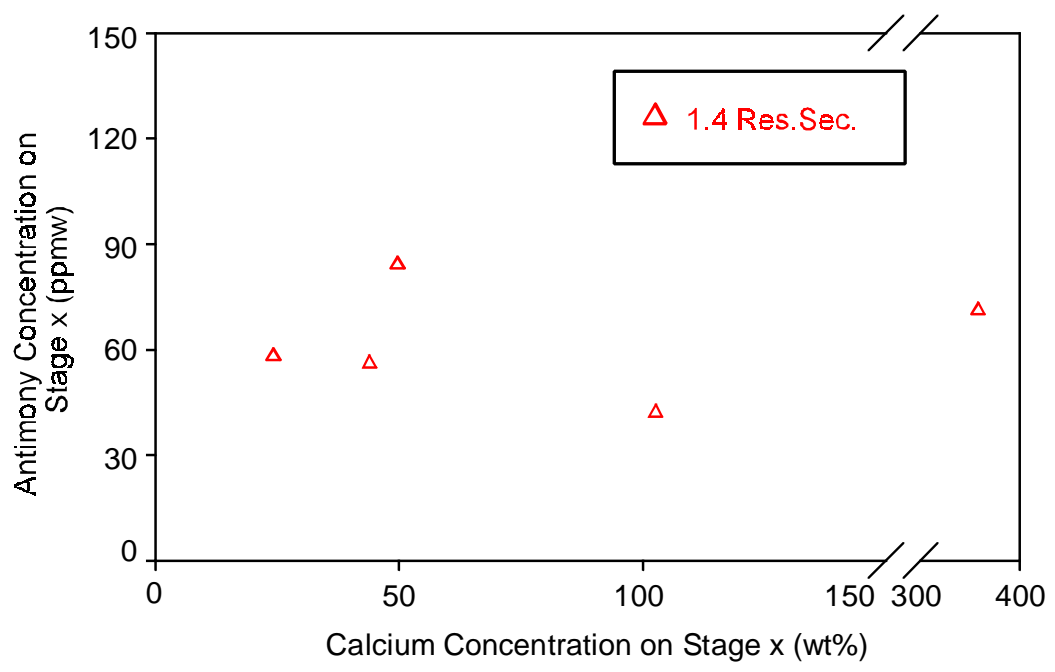

(a)

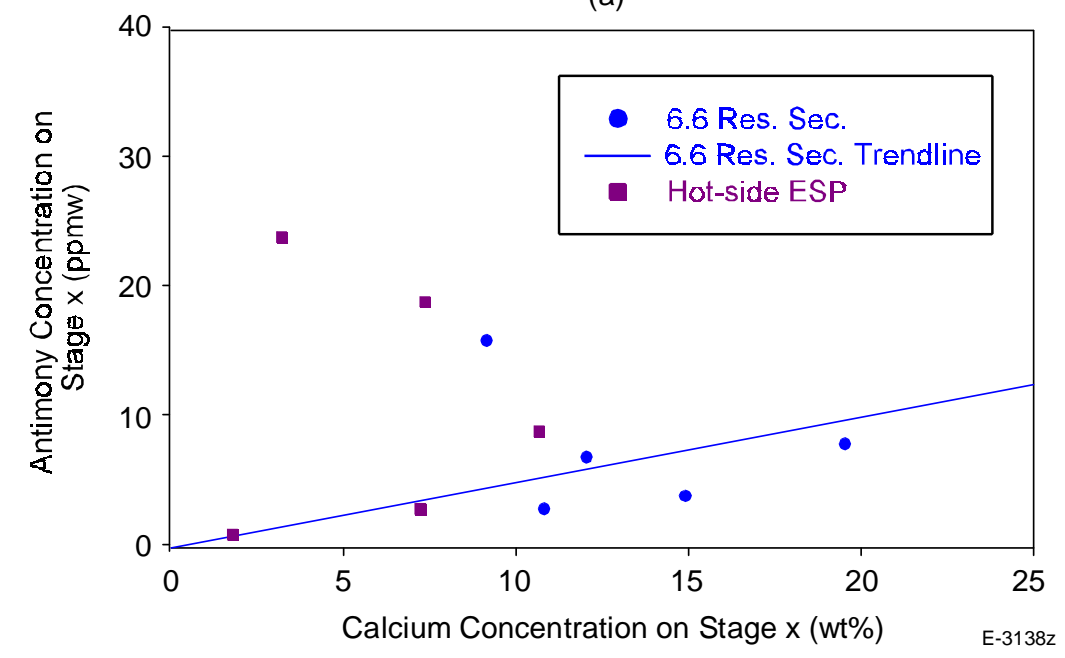

(b)

Figure 3-42. Antimony-calcium correlation for Wyodak fly ash a) 1.4 seconds and b) 6.6 seconds and hot-side ESP conditions.

$\underline{\text { Elemental Analysis }}$

Both sample sets were selected for analysis of size-segregated particle metal content at the University of Arizona by AA/GFAA. Appendix E gives the preliminary analytical results. Table E-1 summarizes the preliminary analytical results for the major species as analyzed by AAS and AES. Table E-2 provides typical trace element concentrations for all elements analyzed by GFAA.

The typical concentration values from Table E-2 were used to generate individual element distribution profiles ${ }^{1}$ for some of the more important trace elements (As, $\mathrm{Se}, \mathrm{Cd}, \mathrm{Co}, \mathrm{Sb}$, and $\mathrm{Cr}$ ). These are shown in Figure 3-45. Cadmium results represent major outliers compared to 


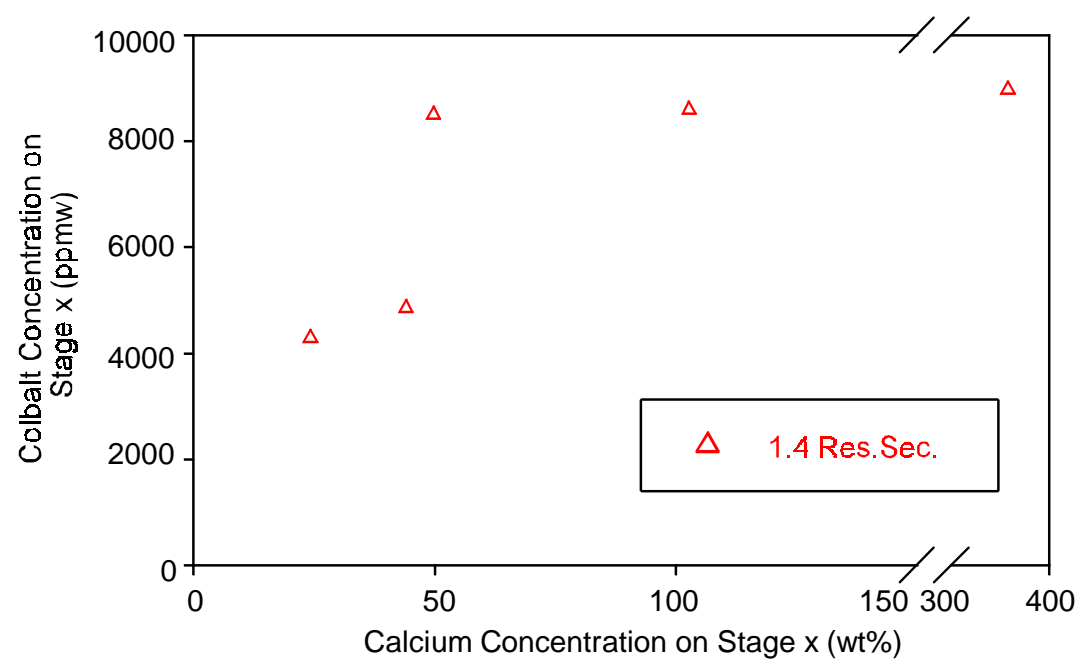

(a)

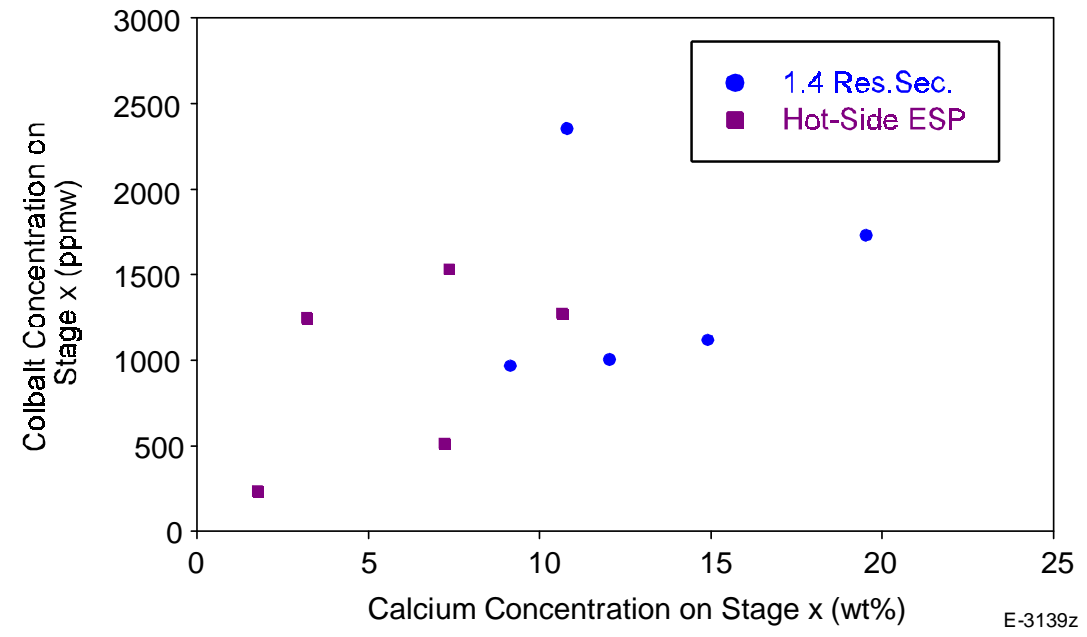

(b)

Figure 3-43. Chromium-calcium correlation for Wyodak fly ash a) 1.4 seconds and b) 6.6 seconds and hot-side ESP conditions.

the other results obtained and the information developed should be viewed with caution. We believe these results to be inaccurate. The $\mathrm{Cd}$ concentrations obtained from these experiments were abnormally high and are most likely the result of contamination from previous experiments conducted on this furnace involving cadmium. 
Table 3-8. A Summary of the Illinois No. 6 Hot-Side ESP Baseline Test Runs

\begin{tabular}{|l|l|l|l|l|l|}
\hline $\begin{array}{l}\text { Test Run } \\
\#\end{array}$ & Date & Coal Feed Rate & Sample Set \# & Sampling Times & Sample Port Used \\
\hline \hline 99IL-1 & $03 / 14 / 99$ & $2.2 \mathrm{~kg} / \mathrm{hr}$ & 99IL-1 & $10 \mathrm{~min} 41 \mathrm{sec}$ & BG $^{*}$ \\
\hline & & & 99IL-2 & $15 \mathrm{~min}$ & BG \\
\hline
\end{tabular}

Table 3-9. A Summary of Experimental Sampling Conditions For Illinois No. 6 Baseline Run

\begin{tabular}{|c|c|c|c|c|c|c|c|c|c|}
\hline $\begin{array}{c}\text { Sample Set \# } \\
\text { (Port Sampled) }\end{array}$ & $\begin{array}{c}\text { Total } \\
\text { Combustion } \\
\text { Gas Rate } \\
\text { (Slpm) } \\
\end{array}$ & $\begin{array}{c}\text { Sampling } \\
\text { Rate } \\
\text { (Slpm) } \\
\end{array}$ & $\begin{array}{c}\text { Sampling Temp. } \\
\left({ }^{\circ} \mathrm{C} \text { at Port }\right. \\
\text { Where Sample } \\
\text { Was Taken }) \\
\end{array}$ & $\begin{array}{c}\text { Port } 4 \\
\mathrm{O}_{2} \text { Conc } \\
(\%) \\
\end{array}$ & $\begin{array}{c}\text { Port } 4 \\
\mathrm{Co}_{2} \text { Conc } \\
(\%) \\
\end{array}$ & $\begin{array}{c}\text { Port } 14 \\
\mathrm{O}_{2} \text { Conc } \\
(\%) \\
\end{array}$ & $\begin{array}{c}\text { Port } 14 \\
\mathrm{CO}_{2} \text { Conc } \\
(\%) \\
\end{array}$ & $\begin{array}{c}\text { Port } \mathrm{BG}^{\dagger} \\
\mathrm{O}_{2} \text { Conc } \\
(\%) \\
\end{array}$ & $\begin{array}{c}\text { Port BG } \\
\mathrm{Co}_{2} \mathrm{Conc} \\
(\%) \\
\end{array}$ \\
\hline $\begin{array}{c}\text { 99IL-1 } \\
\text { (BG) }\end{array}$ & $418^{\ddagger}$ & 1.22 & 217 & 3.7 & 16.0 & 5.4 & 14.4 & 8.1 & 11.8 \\
\hline $\begin{array}{l}\text { 99IL-2 } \\
(\mathrm{BG})\end{array}$ & 418 & 1.22 & 217 & 3.7 & 16.0 & $\overline{5.4}$ & 14.4 & 8.1 & 11.8 \\
\hline
\end{tabular}

"BG - Baghouse inlet sample port.

${ }^{\top} \mathrm{BG}=$ Baghouse inlet sampling port.

Sampling rate for BG samples is $65 \%$ of isokinetic. 


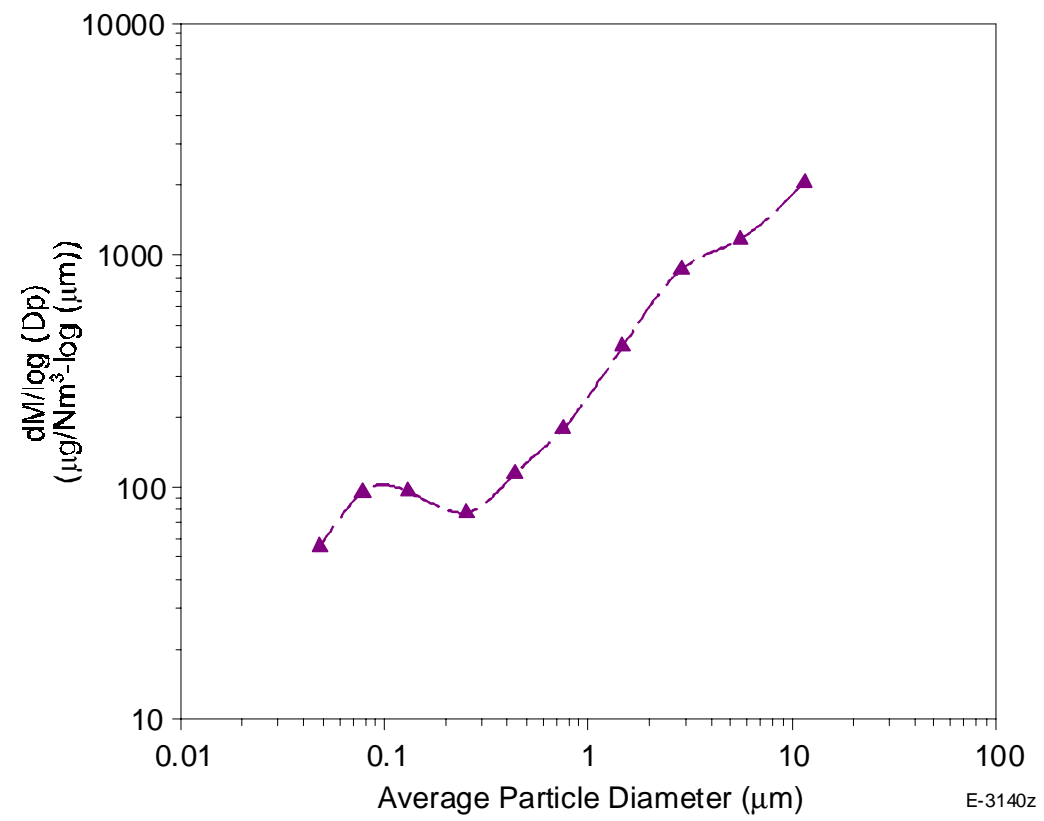

Figure 3-44. Typical particle size distribution for Illinois No. 6 fly ash collected at hot-side ESP conditions.

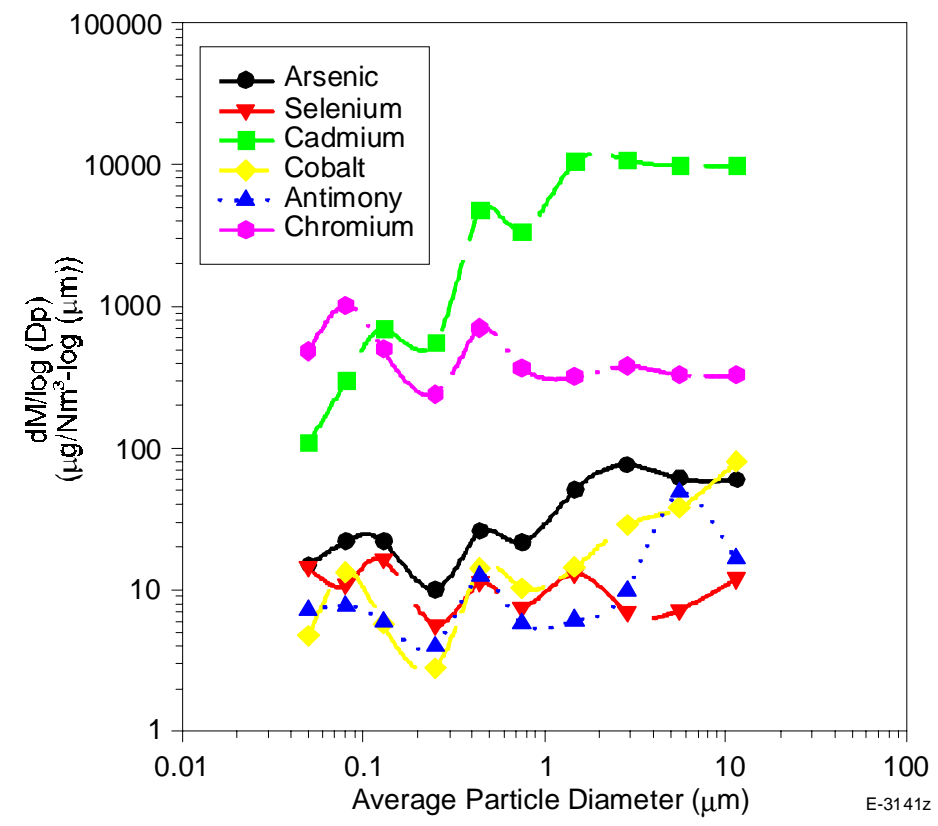

Figure 3-45. Typical trace element distributions in Illinois No. 6 fly ash collected at hot-side ESP conditions. 


\subsubsection{Measurement of Post-Combustion Chlorine Speciation}

Chlorine and $\mathrm{HCl}$ are classified by the EPA as hazardous air pollutants. Mercury is found as a trace component of coal combustion flue gas. Chlorine gas is active in the oxidation of mercury in the flue gas. $\mathrm{Cl}_{2}$ will react with elemental mercury to oxidize it. In its oxidized form, it is possible to scrub the mercury from the flue gas and prevent it from being emitted into the atmosphere.

We are interested in determining the speciation of chlorine in flue gas. In the Phase I Final report, it was estimated that only one percent of the chlorine is $\mathrm{Cl}_{2}$ and the rest is $\mathrm{HCl}$. We want to experimentally determine the ratio of $\mathrm{Cl}_{2}$ to $\mathrm{HCl}$. Chlorine speciation is to be determined using EPA Method 26. This method uses a series of acidic and basic solutions to capture the chlorine. The solution will then be analyzed using ion chromatography. However, there is some concern that sulphur dioxide may interfere with the collection efficiency, positively biasing $\mathrm{HCl}$ recovery. This is the proposed reaction.

$$
\mathrm{SO}_{2}+\mathrm{Cl}_{2}+2 \mathrm{H}_{2} \mathrm{O}=4 \mathrm{H}^{+}+2 \mathrm{Cl}^{-}+\mathrm{SO}_{4}^{-2}
$$

We will test the effects of $\mathrm{SO}_{2}$ on chlorine speciation using synthetic flue gas. If interference does occur, we will use another method of collection that quantifies the total chlorine present. $\mathrm{Cl}_{2}$ concentration is determined in a separate solution through a reaction with potassium iodine. The $\mathrm{Cl}_{2}$ will oxidize the iodine on a one to one basis. This method is very similar to EPA Method 26, but the solutions are in parallel, not in series. Ion chromatography will be used to measure total chlorine concentration and iodine concentration. These two methods should give us clear separation on chlorine species. We have set up the collection train. The components for the synthetic flue gases have been received. Trial runs to check the effects of $\mathrm{SO}_{2}$ will begin next quarter.

\subsubsection{Bench-Scale Investigation of Gaseous Mercury Chemistry}

\subsubsection{Flat Flame Burner System for Mercury Oxidation Experiments}

Design and construction of a bench-scale facility at the University of Connecticut to study the homogeneous and heterogeneous oxidation of mercury under post-flame conditions is nearly complete. The system is illustrated in Figure 3-46. It consists of a gas control panel, mercury generation unit, flat flame burner, viewing tower, mixing chamber, quartz tube, probe, and an Ontario Hydro analytical train. There are in total six feed lines of gases supplying both the flat flame burner and the mixing chamber. Mass flow controllers are used to measure and control the flow of oxygen, methane, and nitrogen for mercury generation. Rotameters are employed for pure nitrogen, nitrogen plus hydrochloric acid, and nitrogen/helium plus chlorine. Both types of instruments have been calibrated with a wet test meter.

The central part of this system is a multi-element flat flame diffusion burner with central feed tube, manufactured by Research Technologies Inc. of Pleasanton, California. According to the manufacturer, the burner operates at optimum conditions between 25 and $40 \mathrm{slpm}$. In this 


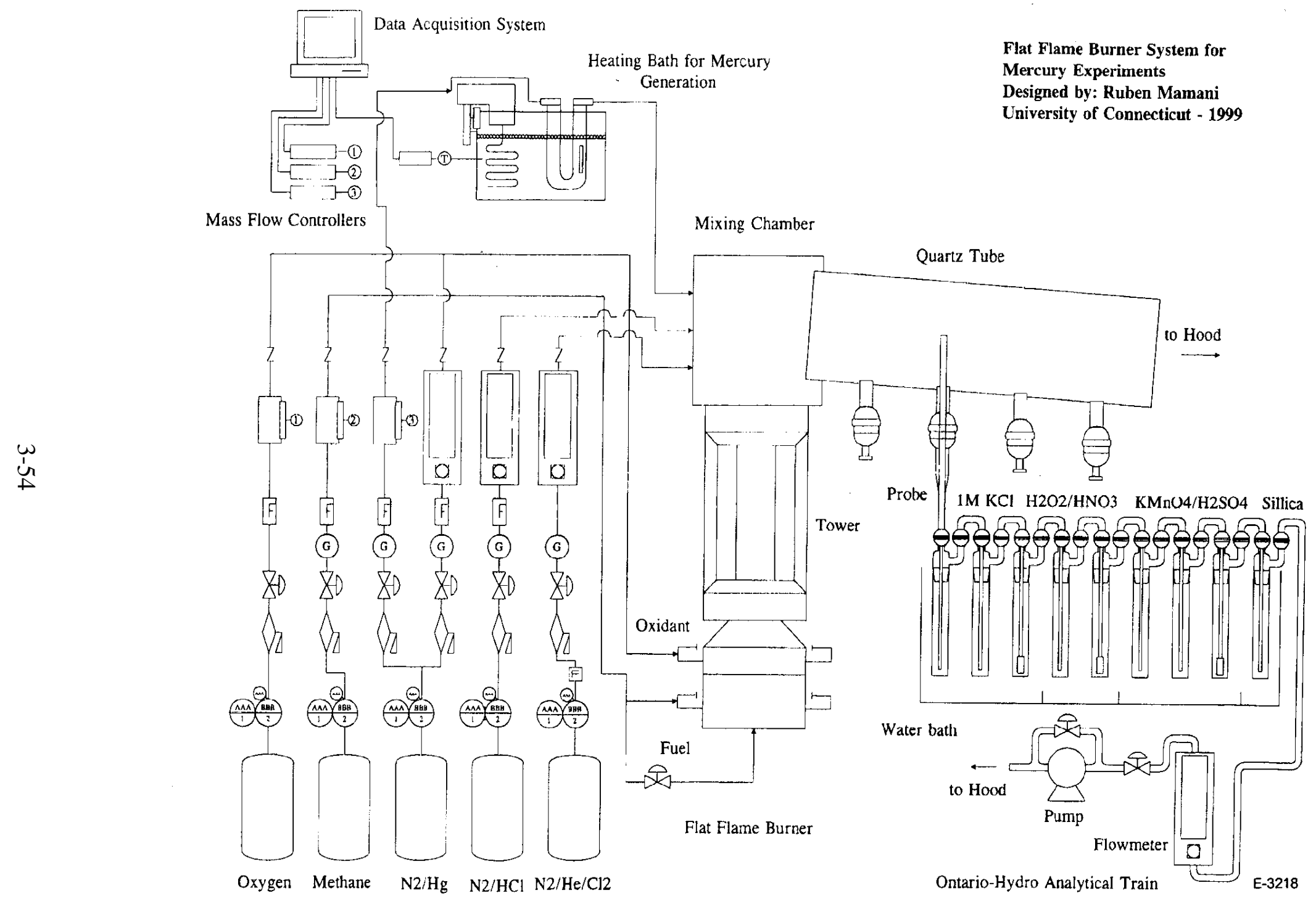

Figure 3-46. Flat flame burner system. 
study, the burner will be operated at flow rates between 26 and 29 slpm, with an equivalence ratio close to 1 . The equivalence ratio can be adjusted to provide control over the reactor temperature profile as well as post-combustion gas composition. If simultaneous control proves difficult, additional gases (e.g., $\mathrm{CO}_{2}$ ) can be added downstream of the flame zone. The burner will operate under fuel-lean conditions in all experiments.

On top of the burner, a 30-cm viewing quartz tower is installed. Methane, oxygen and pure nitrogen can be fed into the flat flame burner at specific mixing ratios in order to achieve desired temperatures at the top of the viewing tower. A stainless steel mixing chamber is located at the top of the viewing tower. Besides the connection to the tower, it has three incoming lines and a wide $(13.5 \mathrm{~cm})$ opening at the outlet for a quartz reaction tube. The mixing chamber receives the gases resulting from the oxidation of methane $\left(\mathrm{CO}_{2}\right.$ and $\left.\mathrm{H}_{2} \mathrm{O}\right)$ and nitrogen. Mercury, $\mathrm{HCl}$ and $\mathrm{Cl}_{2}$ can be fed into the system through this unit, using nitrogen or helium as carrier gases. The outlet of the mixing chamber is connected to an $80-\mathrm{cm}$ quartz tube which is inclined about 5 deg from horizontal.

There are four side connectors along the quartz tube. The flue gas passes through the quartz tube and it is cooled as it exits to the hood. The connectors are used to insert the quartz probe which will sample flue gas at different temperatures. The quartz probe samples gas at the center of the quartz reaction tube. It is maintained at temperatures above $120^{\circ} \mathrm{C}$, consistent with Ontario Hydro specifications. The quartz probe conducts the flue gas into the Ontario Hydro analytical train. The Ontario Hydro analytical train consists of nine impingers containing solutions to capture oxidized and elemental mercury. The flow rate is then measured and the gas exits to the hood. A pump is used to create the differential pressure necessary to achieve the necessary gas flow through the impingers.

A mercury permeation device from VICI Metronics is used to provide a steady feed of $\mathrm{Hg}^{0}$ to the reactor. The device is placed inside a U-shaped tube holder which in turn is placed in a constant temperature heating bath. The temperature of the heating bath is monitored through a data acquisition system which receives data from a thermister located inside the bath. It also records mass flow data coming from the mass flow controllers. Temperature inside the quartz tube is also monitored through the use of a thermocouple. Using this system, mercury concentrations ranging from 20 to $100 \mathrm{mg} / \mathrm{m}^{3}$ can be achieved.

\subsubsection{Temperature Distribution in Flat Flame Burner System}

In order to study mercury reactions under post-coal combustion conditions $\left(600^{\circ} \mathrm{C}\right.$ to $200^{\circ} \mathrm{C}$ ), gas flow conditions to achieve such temperatures need to be determined. Our objective is to achieve temperatures between $800^{\circ} \mathrm{C}$ and $1000^{\circ} \mathrm{C}$ at the top of the viewing tower to obtain the desired temperatures in the mixing chamber and quartz reaction tube. Temperatures at the outlet of the mixing chamber will therefore be measured and compared to the temperature at the top of the viewing tower under the same gas flow conditions.

Three sets of measurements were made. The first were conducted using fuel lean conditions corresponding to an overall equivalence ratio of 0.4: 2 slpm methane, 10 slpm oxygen, 
and 14 slpm nitrogen. Different variations on these conditions were then considered. Temperatures were measured at the bottom and top of the viewing tower, with radial positions of center, $1 \mathrm{~cm}$, and $2 \mathrm{~cm}$, as indicated in Table 3-10 and Figures 3-47 through 3-49.

Table 3-10. Flow conditions at Different Equivalence Ratios

\begin{tabular}{|l|c|c|c|c|c|c|}
\hline Eq. Ratio & 1 & 0.4 & 0.33 & 0.26 & 0.4 & 0.5 \\
\hline $\mathrm{N}_{2}$ slpm & 10 & 14 & 16 & 20 & 14 & 13 \\
\hline $\mathrm{CH}_{4}$ slpm & 2 & 2 & 2 & 2 & 2 & 2 \\
\hline $\mathrm{O}_{2}$ slpm & 4 & 10 & 12 & 15 & 10 & 8 \\
\hline
\end{tabular}

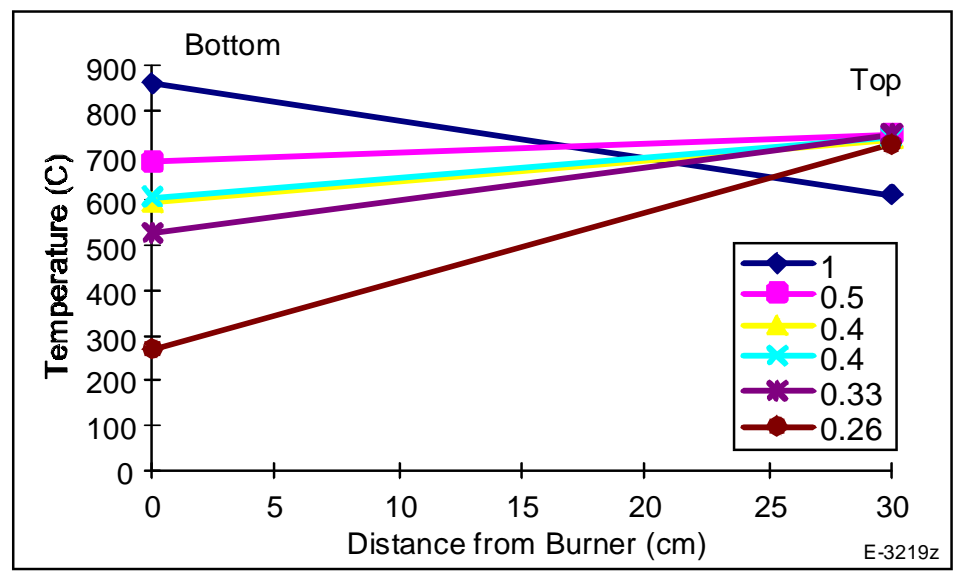

Figure 3-47. Temperature profiles at different equivalence ratios, at the top and bottom of tower on centerline. (Temperatures not corrected for thermocouple error.)

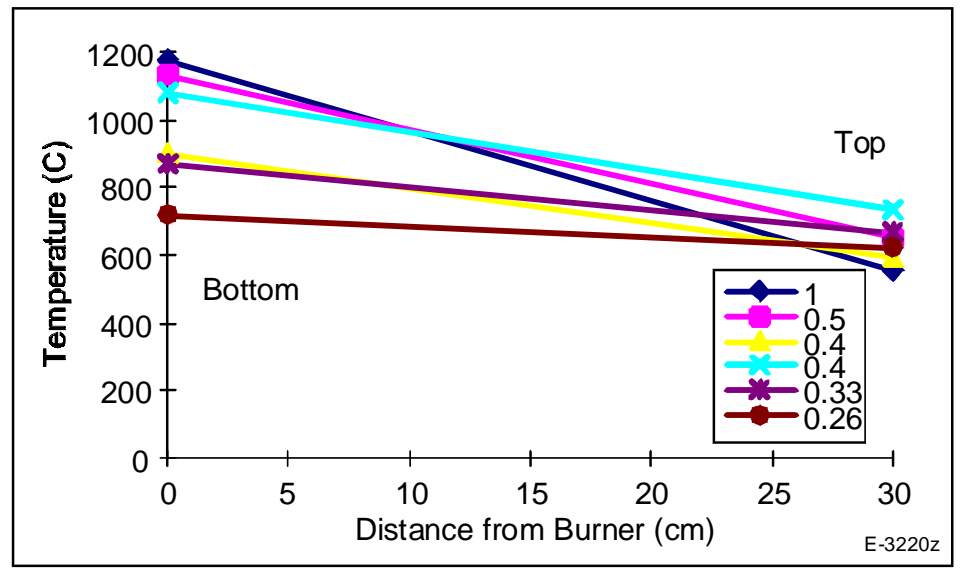

Figure 3-48. Temperature profiles at different equivalence ratios, at the top and bottom of tower, $1 \mathrm{~cm}$ off center. (Temperatures not corrected for thermocouple error.) 


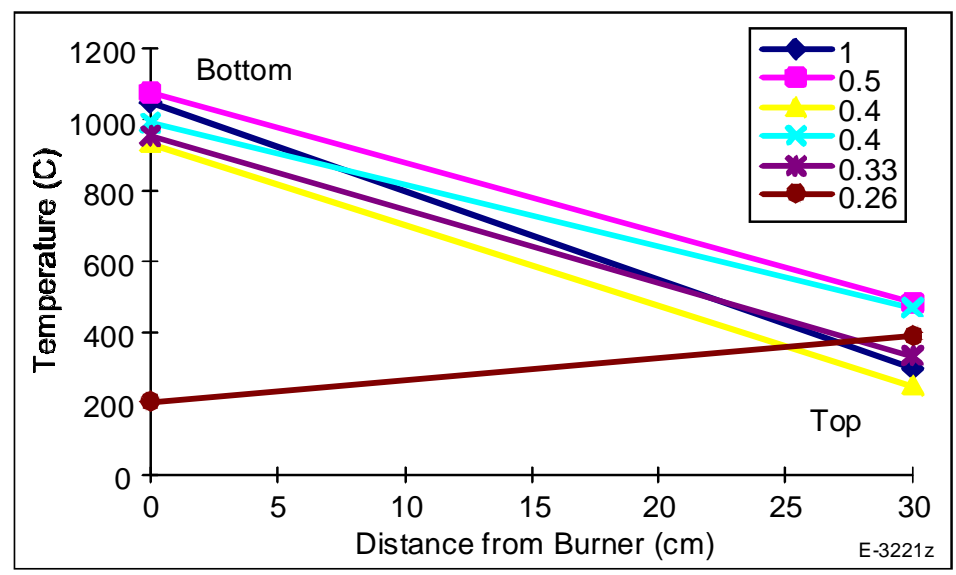

Figure 3-49. Temperature profiles at different equivalence ratios, at the top and bottom of tower, $2 \mathrm{~cm}$ off center. (Temperatures not corrected for thermocouple error.)

The second set of experiments consisted of temperature measurements at different radial positions at the outlet of the mixing chamber. This site corresponds to the beginning of the quartz tube reactor. Previous gas flow conditions were used in order to compare to the results of the first set of experiments. Results are found in Table 3-11.

Table 3-11. Temperature Measurements at the Outlet of Insulated Mixing Chamber (in degrees Celsius) $\mathrm{CH}_{4}=2$ slpm, $\mathrm{O}_{2}=10$ slpm, $\mathrm{N}_{2}=14$ slpm. Equivalence Ratio $=0.4$

\begin{tabular}{|l|c|c|c|c|}
\hline Radial Distance & Left & Right & Up & Down \\
\hline \hline Center, $0 \mathrm{~cm}$ & 245 & 245 & 245 & 245 \\
\hline $\mathrm{T} 2 \mathrm{~cm}$ & 332 & 301 & 246 & 269 \\
\hline $\mathrm{T} 4 \mathrm{~cm}$ & 340 & 338 & 298 & 263 \\
\hline $\mathrm{T} 6 \mathrm{~cm}$ & 315 & 324 & 327 & 220 \\
\hline
\end{tabular}

The third set of experiments were done using gas flow rates with equivalence ratios close to one, at which conditions the highest temperatures can be achieved. Results are reported in Table 3-12 and Figures 3-50 through 3-52.

The first set of measurements indicated that operation under very fuel lean conditions would not provide the desired temperature profile in the mixing chamber and quartz reaction tube. All of the temperatures obtained at the top of the viewing tower were less than $800^{\circ} \mathrm{C}$. The highest temperature achieved was $748^{\circ} \mathrm{C}$ with an equivalence ratio of 0.33 . It should be noted that taking into consideration the radiation correction to the error of thermocouple reading, actual temperatures will be approximately $85^{\circ} \mathrm{C}$ less at the top of the viewing tower. ${ }^{7}$ For an 
Table 3-12. Flow Conditions for Temperature Measurement Experiments

\begin{tabular}{|l|c|r|r|r|r|r|c|}
\hline \multicolumn{1}{|c|}{ Run } & \multicolumn{1}{c|}{1} & \multicolumn{1}{c|}{2} & \multicolumn{1}{c|}{3} & \multicolumn{1}{c|}{4} & \multicolumn{1}{c|}{5} & 6 & 7 \\
\hline \hline $\begin{array}{l}\text { Equiv. } \\
\text { Ratio }\end{array}$ & 1 & 1 & 1 & 0.8 & 0.8 & 1 & 1 \\
\hline $\begin{array}{l}\mathrm{CH}_{4} \\
\text { slpm }\end{array}$ & 3 & 4 & 5 & 3.4 & 5 & 3 & 4 \\
\hline $\mathrm{O}_{2}$ slpm & 6 & 8 & 10 & 8.6 & 12.5 & 6 & 8 \\
\hline $\mathrm{N}_{2}$ slpm & 17 & 14 & 11 & 14 & 8.5 & 17 & 17 \\
\hline $\begin{array}{l}\text { Flame } \\
\text { Color }\end{array}$ & Blue & $\begin{array}{c}\text { Blue/ } \\
\text { Yellow }\end{array}$ & Yellow & $\begin{array}{c}\text { Blue/ } \\
\text { Yellow }\end{array}$ & Yellow & Blue & Blue \\
\hline
\end{tabular}

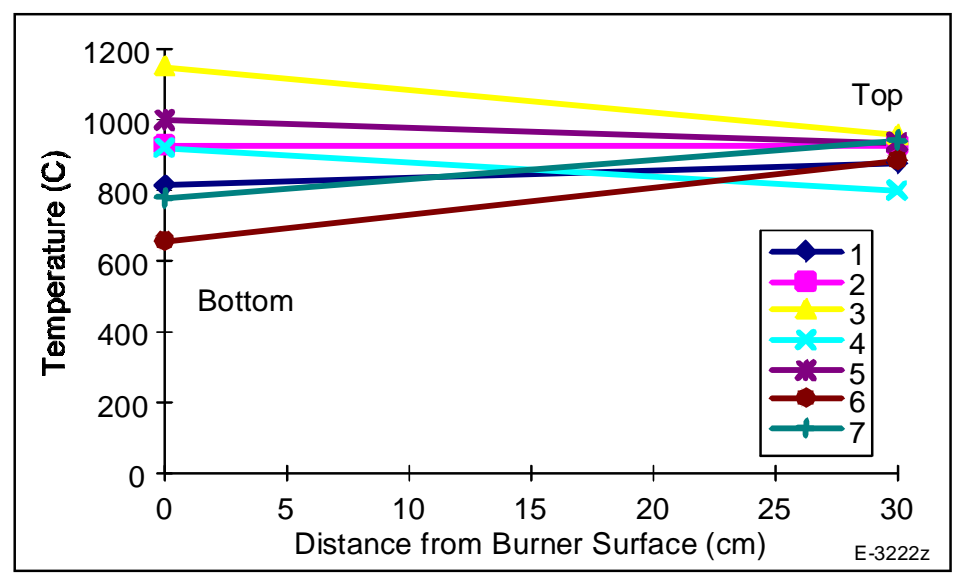

Figure 3-50. Temperature profiles at different flow rates, similar equivalence ratios, runs 1 to 7 of Table 3-12 on centerline. (Temperatures not corrected for thermocouple error.)

equivalence ratio of 0.4 , the average temperatures were $527^{\circ} \mathrm{C}$ and $648^{\circ} \mathrm{C}$ at columns 2 and 5 , respectively, at the top of the viewing tower. With an equivalence ratio of 0.4 and the insulated mixing chamber on top, the average temperature of all radial measurements at the outlet was $294^{\circ} \mathrm{C}$ (Table 3-11). Comparing this value with the temperatures at the top of the viewing tower $\left(527^{\circ} \mathrm{C}\right.$ and $\left.648^{\circ} \mathrm{C}\right)$, the temperature loss through the mixing chamber was observed to be in the range of 234 and $355^{\circ} \mathrm{C}$.

The third set of measurements indicated that, as expected, much higher temperatures could be obtained at the top of the viewing tower when operating closer to stoichiometric conditions. Most of the values obtained were within the range of $800^{\circ} \mathrm{C}$ to $1000^{\circ} \mathrm{C}$. In some cases, flame uniformity was not maintained and a large yellow flame was observed. 


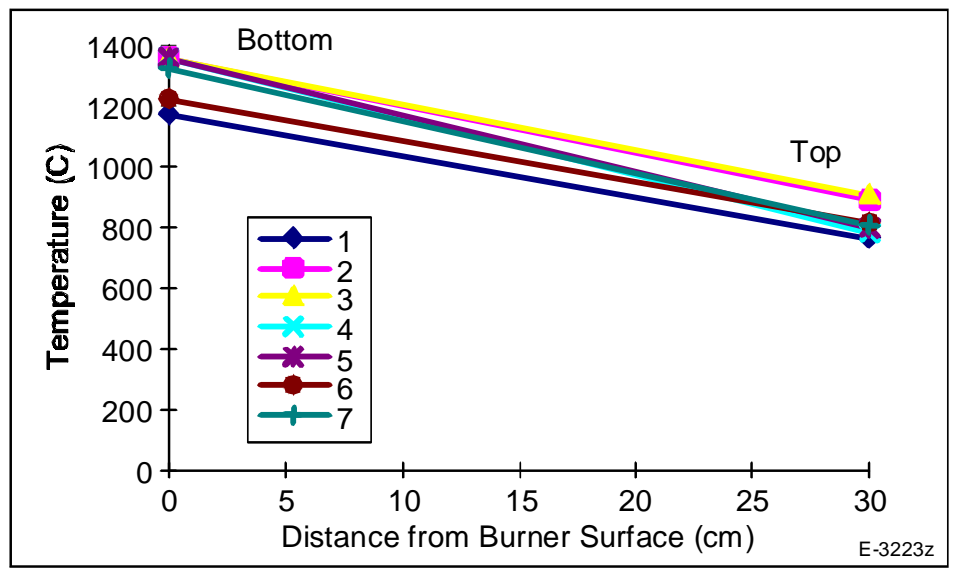

Figure 3-51. Temperature profiles at different flow rates, similar equivalence ratios, runs 1 to 7 of Table 3-12, $1 \mathrm{~cm}$ off centerline. (Temperatures not corrected for thermocouple error.)

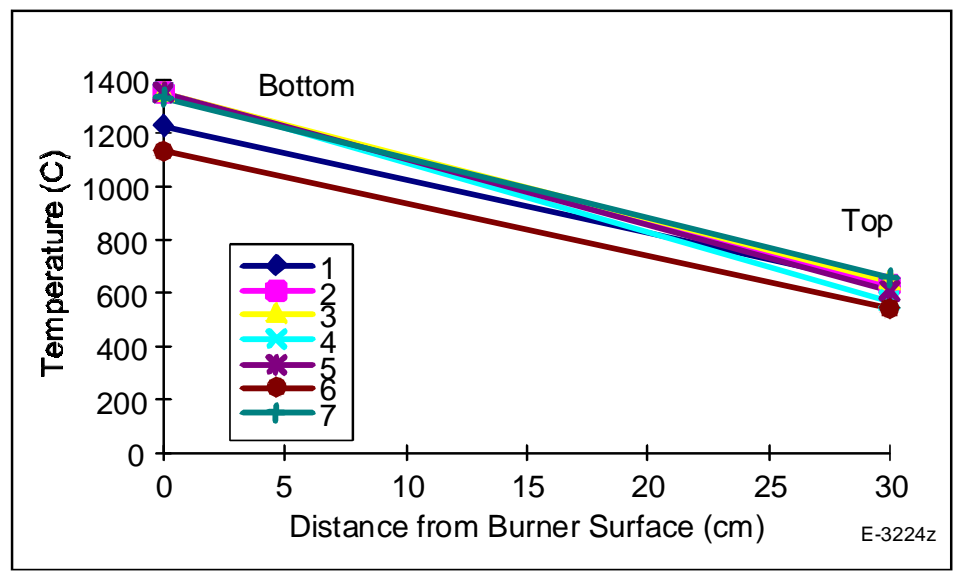

Figure 3-52. Temperature profiles at different flow rates, similar equivalence ratios, runs 1 to 7 of Table 3, $2 \mathrm{~cm}$ off centerline. (Temperatures not corrected for thermocouple error.)

The first two sets of measurements provided preliminary information about the temperatures that could be achieved at the outlet of the mixing chamber and the temperature drop through it. While these specific conditions provide temperatures that are too low for the study of mercury reaction chemistry, the higher tower temperatures obtained under stoichiometric combustion conditions suggest that appropriate post combustion temperatures can be obtained.

Measurements of the mixing chamber temperature profile under these conditions are underway. 


\subsubsection{XAFS Study of Mercury in Ash and Sorbents}

The mathematical simulation of the expected $\mathrm{Hg}$ XANES parameter (inflections point difference, IPD, and peak-height ratio, $\mathrm{HR}$ ) trends for mixtures of $\mathrm{HgCl}_{2}$ and $\mathrm{Hg}^{0}$, the two most likely $\mathrm{Hg}$ species present in combustion flue gases, was completed. The spectra were simulated using the Breit-Wigner expression for a lorentzian peak shape, which approximately simulates the shape of the first derivative peaks obtained from the $\mathrm{Hg}$ XANES spectra. To simulate the $\mathrm{HgCl}_{2}$ spectrum a two-peak expression was generated, based on experimental data for peak positions and widths, and this was added to a single-peak expression for $\mathrm{Hg}^{0}$ to simulate mixtures of the two mercury species. This simulation was then compared to an experimental simulation involving weighted additions of the experimental Hg XANES spectra for the two species. The agreement between the two simulations of the expected data trend was found to be very good (Figure 3-53). The simulations were then compared to the data trend for the $\mathrm{Hg}$-impregnated chars generated at the University of Arizona (U. Az). The simulations did not closely reproduce the data trend for the $\mathrm{U}$. Az chars. A possible reason for this is that the vapor phase $\mathrm{Hg}^{0}$ interacts with the char surface to form a $\mathrm{Hg}-\mathrm{C}$ or possibly a $\mathrm{Hg}-\mathrm{S}$ complex, and hence the single peak simulation for $\mathrm{Hg}^{0}$ is inappropriate in both simulations. However, those chars exposed to $\mathrm{HgCl}_{2}$ in the $\mathrm{U}$. $\mathrm{Az}$. combustor had values of the height ratio and IPD that were very close to the $\mathrm{HgCl}_{2}$ ends of the simulation. It would appear that the $\mathrm{Hg}$ captured by the chars with $\mathrm{HgCl}_{2}$ in the flue gas occurs by a predominantly physisorption mechanism, as there is no change in the mercury speciation. However, with $\mathrm{Hg}^{0}$ in the flue gas, the evidence suggests there is a change in

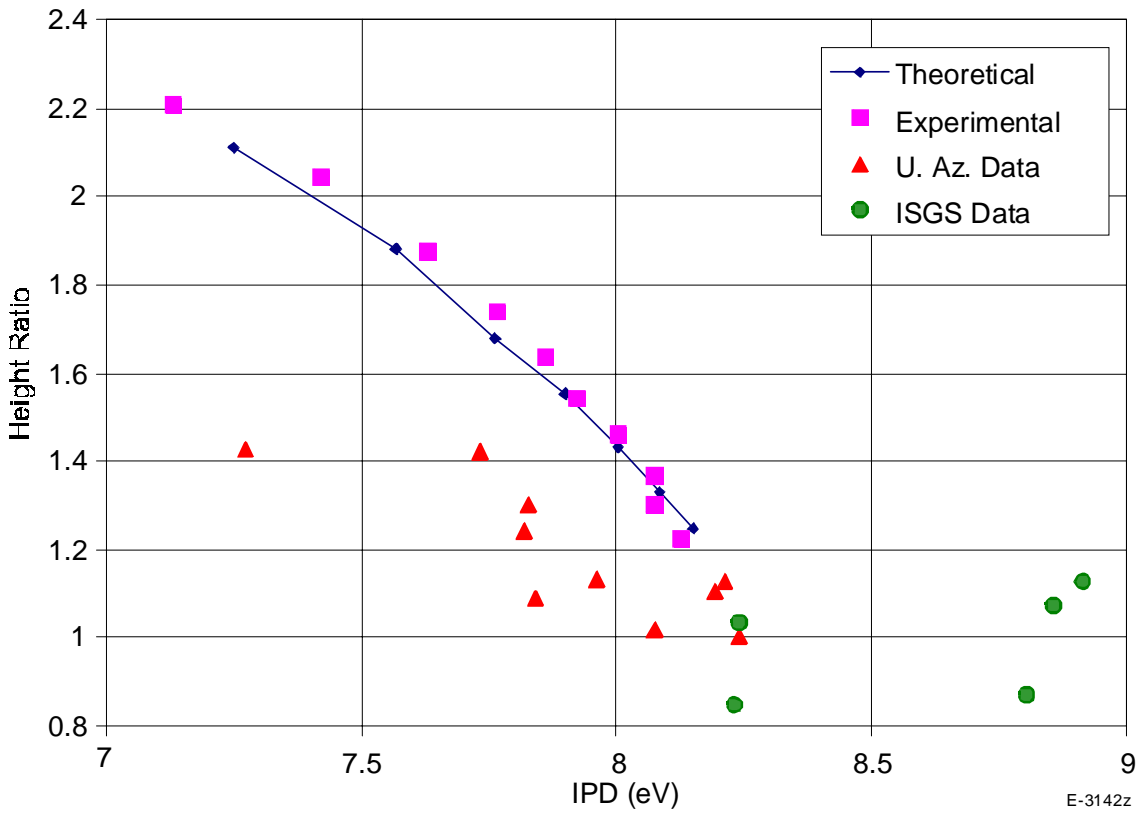

Figure 3-53. Comparison of the spectral simulation trends with data obtained from $\mathrm{Hg}$ impregnated chars obtained from the University of Arizona combustor. 
speciation to either a mixture of $\mathrm{Hg}-\mathrm{Cl}, \mathrm{Hg}-\mathrm{C}$, and possibly $\mathrm{Hg}-\mathrm{S}$ species, or a mixed species. Such a mechanism would be predominantly chemisorption. As the data trend is toward lower values of IPD and away from $\mathrm{HgCl}_{2}$, it is pretty certain that $\mathrm{Hg}-\mathrm{O}$ bonding is not involved in the formation of the $\mathrm{Hg}$ char complexes.

Data were also obtained on the Cherokee fly-ash sample subjected to triboelectrostatic separation (TES) and the data shown in Table 3-13 were obtained for the three fractions generated by this separation technology.

Table 3-13. Data for Triboelectrostatic Separation on ADA Cherokee Fly Ash Sample

\begin{tabular}{|l|c|c|c|}
\hline $\begin{array}{l}\text { Sample } \\
\text { (fraction) }\end{array}$ & Wt\% & $\begin{array}{c}\text { Carbon content } \\
(\text { wt \%) }\end{array}$ & $\begin{array}{c}\text { Mercury Content } \\
\text { (ppm) }\end{array}$ \\
\hline Bulk Sample & 100 & 8.2 & 158 \\
\hline Positive Fraction & 49.9 & 3.6 & 81 \\
\hline Middle Fraction & 38.9 & 6.4 & 87 \\
\hline Negative Fraction & 11.3 & 13.8 & 745 \\
\hline
\end{tabular}

The mercury contents were determined by CVAAS and the carbon contents by LOI. These measurements were conducted at the University of Kentucky Center for Applied Energy Research. The results seem to imply that there is a carbonaceous fraction which is enriched in mercury because of the positive correlation of mercury content and carbon content (Figure 3-54).

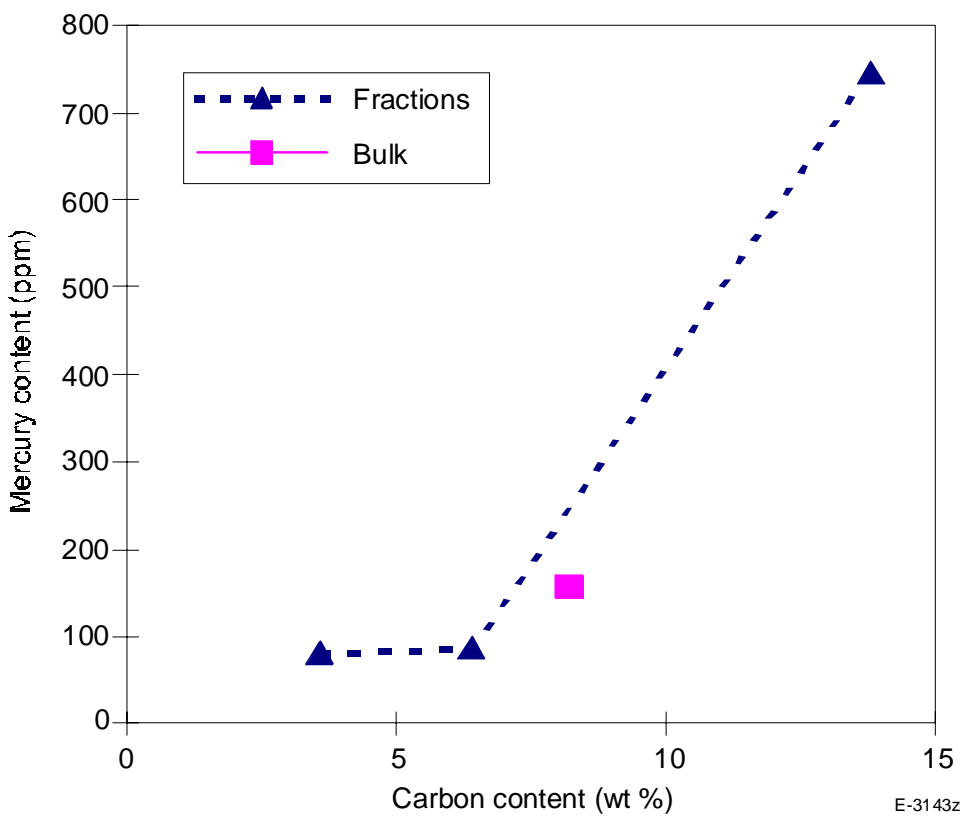

Figure 3-54. Correlation between carbon content and mercury content for fractions of ADA baghouse-hopper fly-ash separated by triboelectrostatic separation. 
However, the fact that the correlation is by no means linear indicates that the system is not a simple two-component system with respect to mercury; that is, it is not simply a mixture of a carbon component with an uniformly high mercury content and a non-carbonaceous component (aluminosilicate glass?) with an uniformly low or zero mercury content. Rather, one must speculate that the mercury content of the carbon is variable and that there may be more than one carbonaceous component. Also, as noted by James Neathery, who did the separation, the middle fraction, which is not deflected towards either electrode, typically contains much coarse carbon particulate matter. Hence, the finest carbonaceous particulate matter, which concentrates towards the negative electrode, may have the highest mercury concentration. This observation would be consistent with a mechanism of surface capture of mercury because the smallest particles have the highest surface area and therefore would have the highest mercury concentrations.

Two other samples of the Hg-impregnated Cherokee fly-ash have also been received from ADA Technologies, Inc. One of these is a second, larger volume, Hg-laden sample, similar to the first sample, whereas the other sample has been subjected to desorption of mercury. These new samples have also been separated by TES and some preliminary data are available for these samples, as summarized in Tables 3-14 and 3-15. The mercury contents of these fractions are currently being measured. All three Cherokee fly-ash samples and the fractions obtained by TES will be examined by Hg XAFS spectroscopy during the next synchrotron session in July.

Table 3-14. Data for Triboelectrostatic Separation on ADA Cherokee Fly-Ash Sample (Hg-Laden)

\begin{tabular}{|l|c|c|c|}
\hline \multicolumn{1}{|c|}{ Sample (fraction) } & $\mathrm{Wt} \%$ & $\begin{array}{c}\text { Carbon content } \\
(\mathrm{wt} \%)\end{array}$ & $\begin{array}{c}\text { Mercury content } \\
(\mathrm{ppm})\end{array}$ \\
\hline \hline Bulk Sample & 100 & 9.6 & $\mathrm{TBD}$ \\
\hline Positive Fraction & 30.7 & 4.7 & $\mathrm{TBD}$ \\
\hline Middle Fraction & 28.9 & 12.9 & TBD \\
\hline Negative Fraction & 26.2 & 10.0 & TBD \\
\hline
\end{tabular}

TBD - To be determined 
Table 3-15. Data for Triboelectrostatic Separation on ADA Cherokee Fly-Ash Sample (Desorbed)

\begin{tabular}{|l|c|c|c|}
\hline \multicolumn{1}{|c|}{ Sample (fraction) } & $\mathrm{Wt} \%$ & $\begin{array}{c}\text { Carbon content } \\
(\mathrm{wt} \%)\end{array}$ & $\begin{array}{c}\text { Mercury content } \\
\text { (ppm) }\end{array}$ \\
\hline \hline Bulk Sample & 100 & 9.9 & $\mathrm{TBD}$ \\
\hline Positive Fraction & 43.6 & 2.9 & TBD \\
\hline Middle Fraction & 28.0 & 13.2 & TBD \\
\hline Negative Fraction & 19.0 & 16.2 & TBD \\
\hline
\end{tabular}

TBD - To be determined 
SECTION 4

SUMMARY AND FUTURE PLANS

4-1/4-2 


\section{SUMMARY AND FUTURE PLANS}

\subsection{Summary}

Low temperature ashing and elemental analysis of the three Phase II coals is complete. Results from MIT and USGS are compared with one another. Concentrations of most trace elements are comparable.

A recurring problem with incomplete pyrite digestion in the $\mathrm{HNO}_{3}$ leaching step has been resolved, but necessitates another complete round of leaching of project samples. In the meantime, USGS personnel are moving forward with XRD mineralogy, ion probe work, and other determinations, and continue to investigate an improved (versus CVAA) method of $\mathrm{Hg}$ determination.

A meeting including personnel from MIT and Utah was held to discuss the NAA results from the initial experiments on loss of trace elements during devolatilization. A plan for another round of testing has been developed and the visiting student who did the work will return to University of Utah this summer to conduct the experiments. Experiments will be conducted on three coals: Ohio (5/6/7), Wyodak, and North Dakota lignite. These will be burned at $1650 \mathrm{~K}$ with a series of oxygen concentrations: $0 \%, 20 \%, 50 \%$, and $100 \%$ oxygen. The balance of the gas will be either nitrogen or carbon dioxide.

The iodated charcoal used for vapor phase $\mathrm{Hg}$ collection was tested to see whether it collected other vapor phase metals. The tests were performed at PSI using the entrained flow reactor (EFR). The Pittsburgh coal from Phase I was burned at $1500^{\circ} \mathrm{C}$ at a stoichiometric ratio of 1.2. As expected, the charcoal in the front sorbent collected $100 \%$ of the vapor phase $\mathrm{Hg}$, and the amount of $\mathrm{Hg}$ collected increased linearly with the test duration. The other element which was collected with $100 \%$ efficiency by the front sorbent was Se.

Data from the University of Arizona self-sustained combustor were analyzed from the combustion of three coals: Ohio, Wyodak and Illinois No. 6 (the latter from Phase I). Ash size distributions and enrichment factors for selected trace elements were calculated. The correlation between the concentration of the more volatile trace elements in the ash and the concentration of major elements such as calcium and aluminum was also examined.

For the Ohio coal, there is evidence for heterogeneous condensation of arsenic vapors on the supermicron ash particles in the post combustion zone as the gas cools from approximately $1350 \mathrm{~K}$ to $1100 \mathrm{~K}$. Selenium vapor appears to condense on the submicron ash particles over the same temperature range. The arsenic concentration in the Ohio ash particles does not show a correlation with calcium content, as one might expect if arsenic vapors were chemically reacting with calcium in the ash. Selenium, however, does show a correlation with calcium in the temperature range of 1100 to $1350 \mathrm{~K}$. These observations suggest that vapor-phase selenium may be more reactive than vapor-phase arsenic with respect to calcium in fly ash. A correlation between cesium and aluminum concentrations in ash suggests the formation of Cs-Al compounds. 
For the Wyodak coal, arsenic, selenium, antimony, and chromium appear to condense preferentially on the submicron ash particles as the gas temperature falls from 1350 to $1100 \mathrm{~K}$. The dependence of concentration of certain trace elements (As, Se, Cd, Co) in the supermicron ash particles on particle diameter suggests that condensation of these elements from the vaporphase is controlled by a chemical reaction (rather than by gas film diffusion). As, Se, and $\mathrm{Cd}$ concentrations in the ash are correlated with the calcium concentration suggesting, once again, the formation of calcium compounds.

Work continued at the University of Utah toward the measurement of chlorine speciation in flue gas. EPA Method 26 will be tested for the ability to speciate chlorine $\left(\mathrm{HCl} v \mathrm{vs} . \mathrm{Cl}_{2}\right)$ in the presence of $\mathrm{SO}_{2}$. If $\mathrm{SO}_{2}$ does cause bias in the measurement, as indicated in the literature, an alternate measurement method will be used to measure $\mathrm{Cl}_{2}$ in parallel with Method 26 .

The University of Connecticut has nearly completed construction of the bench-scale apparatus for examination of the chemistry of mercury in the gas-phase. Preliminary measurements of post-combustion temperatures were made.

During the last quarter, the major focus at the University of Kentucky was to complete an examination of possible trends in XAFS parameters that might reflect $\mathrm{Hg}$ sorption involving mixtures of $\mathrm{Hg}$ and $\mathrm{HgCl}_{2}$ species on carbon-based sorbents. For the University of Arizona char sorbents made from Phase I coals, it would appear that vapor phase $\mathrm{HgCl}_{2}$ is sorbed as $\mathrm{HgCl}_{2}$ (i.e. physisorption), whereas vapor phase $\mathrm{Hg}^{0}$ must react (chemisorption) with species on the char surface to form a chemical complex. Hg-laden and desorbed fly-ash samples obtained from the Cherokee, CO, power plant from collaborators at ADA Technologies have been separated into carbon-rich and carbon-poor fractions by triboelectrostatic separation.

\section{2 $\quad$ Future Plans}

A program review meeting will be held at FETC-Pittsburgh during the next quarter. Results of the recent analytical campaigns by USGS and Kentucky will be presented. Ongoing experimental work at MIT, the University of Utah, the University of Connecticut, the University of Arizona, and EERC will be reviewed. The status of the modeling effort will also be discussed.

Preparation is underway for use of the USGS SHRIMP-RG ion microprobe at Stanford University. Machine time has been reserved on this instrument for the week of 23 August. The initial study will attempt to confirm and quantify the Phase-I finding that measurable $\mathrm{Cr}$ concentrations, and possibly other air toxics, are present in illite, one of the most abundant mineral constituents of bituminous coals.

The next synchrotron runs for NSLS (Brookhaven) and SSRL (Stanford) will take place from 13 to 19 July at Stanford (beam-line IV-3) and from 28 July to 1 August at Brookhaven National Laboratory (beam-lines X-19A and X-18B). Work for the next quarter at the University of Kentucky will therefore consist of the collection and reduction of new XAFS data on program samples submitted for analysis. A paper will also be prepared on XAFS of $\mathrm{Hg}$ sorbents for the 1999 International Ash Utilization Symposium, to be held in Lexington, KY, in October. 
Analysis of ash samples by NAA will continue at MIT once the nuclear reactor comes back on line. Preparations will be made for another test of the sorbent tubes for vapor-phase trace elements using the laboratory scale combustor.

Baseline combustion studies will continue at the University of Arizona with the North Dakota lignite and the Phase I Elkhorn/Hazard bituminous coal. The University of Utah will start another round of devolatilization experiments and begin single particle combustion studies on the laminar flow reactor. Work will also continue on the measurement of chlorine speciation in flue gas. The University of Connecticut will begin bench-scale mercury experiments and continue the kinetic modeling of mercury reactions in flue gas. 
SECTION 5

REFERENCES

$5-1 / 5-2$ 


\section{REFERENCES}

1. Markowski, G.R. and D. S. Ensor, Proc. Of 70th Annual Meeting of the Air Pollution Control Assoc., Toronto, 20-24 June, 1977, Paper No. 77-35-5.

2. Haynes, B.S., Neville, M., Quann, R.J., and A.F. Sarofim, J. of Colloid and Interface Science, 87/1, May, 1982, pp. 266-279.

3. Linak, W.P and J.O.L. Wendt, Fuel Processing Technology, 39:173-198 (1994).

4. Mahuli, S., Agnihotri, R., Chauk, S., Ghosh-Dastidar, A., and L.S. Fan, Environ. Sci. Technol., 31: 3226-3231 (1997).

5. $\quad$ Agnihotri, R., Chauk, S., Mahuli, S., and L.S. Fan, Environ. Sci. Technol., 32: 1841-1846 (1998).

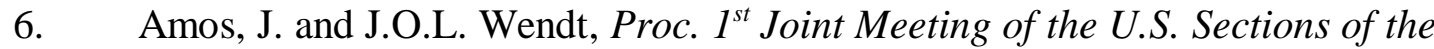
Combustion Institute, Washington, D.C., March 14-17, 1999, Paper No. 98.

7. Hirsch, M.E., "Arsenic speciation in a laboratory combustion system," Dissertation: Thesis (M.S.), University of Connecticut, Storrs, CT,1998. 


\section{APPENDIX A}

$\underline{\text { Trace Element Content of Whole Coal Samples on Dry Basis }}$

A-1/A-2 
Table A-1: Elemental Concentrations for Whole Coals (Values Are in ppm on a Dry Basis)

\begin{tabular}{|l|c|c|c|}
\hline Element & Ohio & Wyodak & ND \\
\hline \hline $\mathrm{Li}$ & 11 & 3.7 & 5.1 \\
\hline $\mathrm{Be}$ & 2.6 & 0.3 & 0.8 \\
\hline $\mathrm{B}$ & 86 & 42 & 130 \\
\hline $\mathrm{Na}$ & 280 & 860 & 3800 \\
\hline $\mathrm{Mg}$ & 340 & 1900 & 4000 \\
\hline $\mathrm{Al}$ & 9100 & 7400 & 9000 \\
\hline $\mathrm{Si}$ & 19000 & 13000 & 25000 \\
\hline $\mathrm{P}$ & 270 & 570 & 170 \\
\hline $\mathrm{K}$ & 1600 & 190 & 1700 \\
\hline $\mathrm{Ca}$ & 1100 & 11000 & 15000 \\
\hline $\mathrm{Sc}$ & 3.8 & 1.9 & 1.9 \\
\hline $\mathrm{Ti}$ & 580 & 670 & 410 \\
\hline $\mathrm{V}$ & 25 & 18 & 15 \\
\hline $\mathrm{Cr}$ & 15.3 & 7.9 & 11.5 \\
\hline $\mathrm{Mn}$ & 20 & 8.2 & 59 \\
\hline $\mathrm{Fe}$ & 14700 & 3030 & 7870 \\
\hline $\mathrm{Co}$ & 4.91 & 5.66 & 9.1 \\
\hline $\mathrm{Ni}$ & 18 & 4.8 & 4.3 \\
\hline $\mathrm{Cu}$ & 9.6 & 14 & 5.5 \\
\hline $\mathrm{Zn}$ & 21 & 8.2 & 12 \\
\hline $\mathrm{Ga}$ & 6.0 & 2.5 & 2.3 \\
\hline $\mathrm{Ge}$ & 9.8 & 0.37 & 1.3 \\
\hline $\mathrm{As}$ & 17.8 & 1.74 & 10 \\
\hline $\mathrm{Se}$ & 1.78 & 1.31 & 0.97 \\
\hline $\mathrm{Br}$ & 18.7 & 1.1 & 2.58 \\
\hline $\mathrm{Rb}$ & 11.3 & 2.1 & 7.2 \\
\hline $\mathrm{Sr}$ & 100 & 260 & 420 \\
\hline $\mathrm{Y}$ & 9.7 & 3.5 & 4.8 \\
\hline $\mathrm{Zr}$ & 14 & 18 & 26 \\
\hline
\end{tabular}


Table A-1: Elemental Concentrations for Whole Coals (Values Are in ppm on a Dry Basis) (Continued)

\begin{tabular}{|l|c|c|c|}
\hline Element & Ohio & Wyodak & ND \\
\hline \hline $\mathrm{Nb}$ & 3.0 & 2.8 & 3.1 \\
\hline $\mathrm{Mo}$ & 4.9 & 1.1 & 2.3 \\
\hline $\mathrm{Ag}$ & $<0.2$ & $<0.2$ & $<0.3$ \\
\hline $\mathrm{Cd}$ & 0.1 & 0.1 & $<0.1$ \\
\hline $\mathrm{Sn}$ & 1.0 & $<0.9$ & $<1.5$ \\
\hline $\mathrm{Sb}$ & 1.94 & 0.23 & 0.70 \\
\hline $\mathrm{Te}$ & $<0.2$ & $<0.2$ & $<0.3$ \\
\hline $\mathrm{Cs}$ & 0.75 & 0.136 & 0.58 \\
\hline $\mathrm{Ba}$ & 66 & 450 & 590 \\
\hline $\mathrm{La}$ & 9.82 & 5.60 & 4.96 \\
\hline $\mathrm{Ce}$ & 18.4 & 9.3 & 7.8 \\
\hline $\mathrm{Sm}$ & 2.17 & 0.96 & 0.75 \\
\hline $\mathrm{Eu}$ & 0.427 & 0.193 & 0.149 \\
\hline $\mathrm{Tb}$ & 0.319 & 0.11 & 0.111 \\
\hline $\mathrm{Yb}$ & 0.98 & 0.42 & 0.49 \\
\hline $\mathrm{Lu}$ & 0.137 & 0.049 & 0.070 \\
\hline $\mathrm{Hf}$ & 0.61 & 0.59 & 0.61 \\
\hline $\mathrm{Ta}$ & 0.20 & 0.159 & 0.137 \\
\hline $\mathrm{W}$ & 1.1 & 0.48 & 2.99 \\
\hline $\mathrm{Au}$ & $<1.0$ & $<0.9$ & $<1.5$ \\
\hline $\mathrm{Hg}$ & 0.18 & 0.13 & 0.08 \\
\hline $\mathrm{Tl}$ & 1.3 & $<0.2$ & $<0.3$ \\
\hline $\mathrm{Pb}$ & 9.1 & 1.9 & 1.5 \\
\hline $\mathrm{Bi}$ & $<0.2$ & $<0.2$ & $<0.3$ \\
\hline $\mathrm{Th}$ & 2.14 & 1.85 & 1.67 \\
\hline $\mathrm{U}$ & 1.25 & 0.73 & 1.12 \\
\hline
\end{tabular}




\section{APPENDIX B}

$\underline{\text { Revisions to } \mathrm{HNO}_{3}}$-Step of USGS Leaching Procedure

B-1/B-2 
$\underline{\text { Memorandum }}$

To: $\quad$ Mode of occurrence leaching-protocol interest group

From: $\quad$ Stan Mroczkowski

Subject: Modification of $\mathrm{HNO}_{3}$ leaching step

Date: June 1, 1999

In the past we have had difficulty removing all of the pyrite from some of the samples we have studied. Samples we had difficulty with included the Elkhorn/Hazard coal from the PSI PRDA Phase I, and two Pittsburgh cleaned coals from the CQ CRADA. More recently, this problem has re-occurred during leaching of the North Dakota lignite and Ohio coal samples from the PSI PRDA Phase II and the Canadian coal from the IEA Round Robin. These last three samples were leached in quadruplicate. The extent of pyrite dissolution varied widely within each sample set regardless of rank or pyrite content.

Recently conducted experiments have revealed the cause of the problem. Samples are normally placed in $50 \mathrm{ml}$ centrifuge tubes on a wrist shaker for 18 hours. Experiments were performed on duplicate raw splits of the above six coals in which the samples were placed in $125 \mathrm{ml}$ Erlenmeyer flasks with $40 \mathrm{ml}$ of $2 \mathrm{~N} \mathrm{HNO}_{3}$. Samples were stirred briefly with Teflon stir-bars to ensure complete wetting and then allowed to sit overnight. This procedure is based on the method for pyritic sulfur determination from ASTM D2492. (The goal in D2492 is to dissolve all of the pyrite, analyze the leachate for Fe, and then calculate the amount of pyritic sulfur based on a stoichiometric ratio with Fe.) Based on Fe determination by flame-AAS, it appears that this procedure successfully removed all of the pyrite from each sample.

The reaction of pyrite with $2 \mathrm{~N} \mathrm{HNO}_{3}$ is relatively slow. In addition, when we arrive at the $\mathrm{HNO}_{3}$ step of the leaching protocol, the sample basically contains only organic-matter and pyrite. This extreme density gradient combined with slow reaction kinetics probably allows the pyrite to settle to the bottom of the centrifuge tubes while it is on the wrist shaker. The problem is compounded by the fact that the centrifuge tubes are pointed at the bottom. Thus, even though the sample is being agitated, the pyrite grains are so dense they probably remain on the bottom of the tube, and therefore may not be sufficiently exposed to the solvent, especially if some of the coal particles cover the pyrite at the bottom of the tube. The flasks, on the other hand, have a very large surface area for the pyrite grains to spread out on, making it much easier for them to contact the solvent.

As an interesting side note, to test this "surface area" theory a separate set of experiments were run. Duplicate raw splits of the same six samples were placed into centrifuge tubes with $\mathrm{HNO}_{3}$ just as before, but instead of placing them on the wrist shaker, they were briefly shaken by hand, and then laid flat on the bench top and allowed to sit overnight. (This effectively distributed the sample along the side of the tube.) All of the pyrite was removed from these samples as well.

Therefore, in light of these data, all future leaching experiments will follow the procedure modified from ASTM D2492, utilizing the Erlenmeyer flasks for the $\mathrm{HNO}_{3}$ step. The rest of the procedure will remain the same. 


\section{APPENDIX C}

Ash Composition from Baseline Combustion Experiments at the University of Arizona for Ohio Coal 
Table C-1. Size-Segregated Major Species Concentration Data Ohio Baseline Coal Combustion at 0.5 Residence Second Conditions

\begin{tabular}{|c|c|c|c|c|c|c|c|c|c|c|c|c|}
\hline \multicolumn{2}{|c|}{ Impactor Stage } & 1 & 2 & 3 & 4 & 5 & 6 & 7 & 8 & 9 & 10 & 11 \\
\hline \multicolumn{2}{|c|}{ Cut-off Diameter（microns) } & 0.0324 & 0.0636 & 0.0926 & 0.168 & 0.337 & 0.535 & 0.973 & 1.96 & 3.77 & 7.33 & 15.7 \\
\hline Element & $\begin{array}{c}\text { Analytical } \\
\text { Method }\end{array}$ & & & & & & & & & & & \\
\hline $\begin{array}{l}\text { Total Mass } \\
\text { Conc }\left(\mathrm{g} / \mathrm{Nm}^{3}\right)\end{array}$ & Gravimetric & 0.020 & 0.028 & 0.083 & 0.046 & 0.040 & 0.091 & 0.945 & 1.255 & 4.110 & 3.909 & 0.973 \\
\hline $\mathrm{SiO}_{2}(\mathrm{Wt} \%)$ & AAS & 11.40 & 8.19 & 5.57 & 14.40 & 12.20 & 22.32 & 28.85 & 42.27 & 44.58 & 47.90 & 43.91 \\
\hline $\mathrm{Al}_{2} \mathrm{O}_{3}(\mathrm{Wt} \%)$ & AAS/NAA & 2.64 & 0.99 & 0.89 & 0.97 & 2.76 & 9.05 & 26.27 & 35.00 & 43.61 & 40.51 & 30.26 \\
\hline $\mathrm{Fe}_{2} \mathrm{O}_{3}(\mathrm{Wt} \%)$ & AAS/NAA & 141.34 & 31.65 & 26.17 & 62.21 & 110.91 & 49.95 & 120.20 & 124.17 & 69.02 & 103.64 & 69.60 \\
\hline $\mathrm{CaO}(\mathrm{Wt} \%)$ & AAS/NAA & 0.42 & 0.20 & 0.14 & 0.14 & 0.45 & 0.70 & 1.41 & 1.43 & 0.94 & 0.78 & 0.77 \\
\hline $\mathrm{MgO}(\mathrm{Wt} \%)$ & AAS/NAA & 0.31 & 0.10 & 0.19 & 0.05 & 0.09 & 0.26 & 0.50 & 0.59 & 0.50 & 0.46 & 0.54 \\
\hline $\mathrm{Na}_{2} \mathrm{O}(\mathrm{Wt} \%)$ & AES/NAA & 3.50 & 2.14 & 2.86 & 2.97 & 3.39 & 1.86 & 3.60 & 3.54 & 2.49 & 1.41 & 3.94 \\
\hline $\mathrm{K}_{2} \mathrm{O}(\mathrm{Wt} \%)$ & NAA & 3.26 & 2.09 & 2.50 & 1.31 & 1.16 & 1.30 & 0.05 & 0.14 & 0.25 & 0.54 & 0.18 \\
\hline $\mathrm{TiO}_{2}(\mathrm{Wt} \%)$ & NAA & 0.13 & 0.06 & 0.08 & 0.05 & 0.18 & 0.30 & 0.01 & 0.03 & 0.04 & 0.13 & 0.05 \\
\hline $\mathrm{Cl}(\mathrm{Wt} \%)$ & NAA & 0.19 & 0.06 & 0.09 & 0.10 & 0.18 & 0.20 & 0.01 & 0.01 & 0.01 & 0.05 & 0.04 \\
\hline $\begin{array}{l}\text { Trace Elements } \\
\text { (Wt\%) }\end{array}$ & GFAA/NAA & 4.08 & 1.35 & 1.49 & 1.47 & 2.38 & 1.21 & 2.55 & 2.58 & 1.08 & 0.86 & 1.06 \\
\hline Total $(\mathrm{Wt} \%)$ & & 167.26 & 46.84 & 40.00 & 83.67 & 133.69 & 87.14 & 183.45 & 209.75 & 162.53 & 196.28 & 150.35 \\
\hline
\end{tabular}

Note: Elemental concentrations have been converted to oxide forms on a $\mathrm{SO}_{3}$-free basis. 
Table C-2. Size-Segregated Major Species Concentration Data Ohio Baseline Coal Combustion at 2.2 Residence Second Conditions

\begin{tabular}{|c|c|c|c|c|c|c|c|c|c|c|c|c|}
\hline \multicolumn{2}{|c|}{ Impactor Stage } & 1 & 2 & 3 & 4 & 5 & 6 & 7 & 8 & 9 & 10 & 11 \\
\hline \multicolumn{2}{|c|}{ Cut-off Diameter (microns) } & 0.0324 & 0.0636 & 0.0926 & 0.168 & 0.337 & 0.535 & 0.973 & 1.96 & 3.77 & 7.33 & 15.7 \\
\hline Element & $\begin{array}{l}\text { Analytical } \\
\text { Method }\end{array}$ & & & & & & & & & & & \\
\hline $\begin{array}{l}\text { Total Mass } \\
\text { Conc }\left(\mathrm{g} / \mathrm{Nm}^{3}\right)\end{array}$ & Gravimetric & 0.020 & 0.064 & 0.038 & 0.019 & 0.004 & 0.012 & 0.560 & 2.037 & 1.148 & 2.252 & 0.834 \\
\hline $\mathrm{SiO}_{2}(\mathrm{Wt} \%)$ & AAS & 4.28 & 11.80 & 3.65 & 8.36 & 22.54 & 183.88 & 155.64 & 27.43 & 45.22 & 41.79 & 31.68 \\
\hline $\mathrm{Al}_{2} \mathrm{O}_{3}(\mathrm{Wt} \%)$ & AAS/NAA & 0.74 & 0.82 & 1.01 & 1.37 & 16.88 & 32.88 & 253.69 & 25.06 & 28.88 & 23.89 & 25.19 \\
\hline $\mathrm{Fe}_{2} \mathrm{O}_{3}(\mathrm{Wt} \%)$ & AAS/NAA & 45.87 & 27.18 & 29.94 & 69.93 & 159.16 & 84.95 & 181.03 & 31.04 & 31.18 & 459.91 & 28.66 \\
\hline $\mathrm{CaO}(\mathrm{Wt} \%)$ & AAS/NAA & 0.20 & 0.34 & 0.48 & 0.33 & 2.58 & 3.43 & 0.55 & 0.67 & 0.86 & 1.00 & 0.92 \\
\hline $\mathrm{MgO}(\mathrm{Wt} \%)$ & AAS/NAA & 0.54 & 0.35 & 0.71 & 0.42 & 1.63 & 1.40 & 3.71 & 0.37 & 0.39 & 0.48 & 0.49 \\
\hline $\mathrm{Na}_{2} \mathrm{O}(\mathrm{Wt} \%)$ & AAS/NAA & 0.20 & 0.88 & 1.46 & 1.86 & 23.20 & 6.90 & 23.22 & 1.09 & 2.14 & 1.37 & 2.47 \\
\hline $\mathrm{K}_{2} \mathrm{O}(\mathrm{Wt} \%)$ & NAA & 0.50 & 0.31 & 0.28 & 0.33 & ND & 2.88 & 0.05 & 0.04 & 0.13 & 0.09 & 0.10 \\
\hline $\mathrm{TiO}_{2}(\mathrm{Wt} \%)$ & NAA & 0.13 & 0.15 & 0.21 & 0.18 & 1.83 & 2.82 & 0.02 & 0.02 & 0.05 & 0.04 & 0.02 \\
\hline $\mathrm{Cl}(\mathrm{Wt} \%)$ & NAA & 0.09 & 0.02 & 0.03 & 0.08 & 0.36 & 0.17 & 0.02 & 0.01 & 0.02 & 0.01 & 0.02 \\
\hline $\begin{array}{l}\text { Trace Elements } \\
(\mathrm{Wt} \%)\end{array}$ & GFAA/NAA & 1.08 & 2.16 & 1.34 & 2.50 & 4.78 & 3.01 & 3.41 & 0.39 & 0.34 & 1.01 & 0.55 \\
\hline Total (Wt\%) & & 53.61 & 44.01 & 39.10 & 85.37 & 232.94 & 322.30 & 621.34 & 86.13 & 109.20 & 529.58 & 90.10 \\
\hline
\end{tabular}

Note: Elemental concentrations have been converted to oxide forms on a $\mathrm{SO}_{3}$-free basis. 
Table C-3. Size-Segregated Major Species Concentration Data Ohio Baseline Coal Combustion at Hot-Side ESP Conditions

\begin{tabular}{|c|c|c|c|c|c|c|c|c|c|c|c|c|}
\hline \multicolumn{2}{|c|}{ Impactor Stage } & 1 & 2 & 3 & 4 & 5 & 6 & 7 & 8 & 9 & 10 & 11 \\
\hline \multicolumn{2}{|c|}{ Cut-off Diameter (microns) } & 0.0324 & 0.0636 & 0.0926 & 0.168 & 0.337 & 0.535 & 0.973 & 1.96 & 3.77 & 7.33 & 15.7 \\
\hline Element & $\begin{array}{c}\text { Analytical } \\
\text { Method }\end{array}$ & & & & & & & & & & & \\
\hline $\begin{array}{l}\text { Total Mass } \\
\text { Conc. }\left(\mathrm{g} / \mathrm{Nm}^{3}\right)\end{array}$ & Gravimetric & 0.002 & 0.012 & 0.014 & 0.006 & 0.003 & 0.005 & 0.077 & 0.072 & 0.082 & 0.211 & 0.141 \\
\hline $\mathrm{SiO}_{2}(\mathrm{Wt} \%)$ & AAS & & 21.98 & 2.64 & 11.87 & 17.95 & 26.56 & 37.62 & 42.18 & 33.32 & 43.02 & 47.71 \\
\hline $\mathrm{Al}_{2} \mathrm{O}_{3}(\mathrm{Wt} \%)$ & AAS & & 1.22 & 0.22 & 0.14 & 1.34 & 2.33 & 1.17 & 0.67 & 1.85 & 0.07 & 0.11 \\
\hline $\mathrm{Fe}_{2} \mathrm{O}_{3}(\mathrm{Wt} \%)$ & AAS & & 55.81 & 13.22 & 41.44 & 64.30 & 67.79 & 37.89 & 31.97 & 33.60 & 33.98 & 55.39 \\
\hline $\mathrm{CaO}(\mathrm{Wt} \%)$ & AAS & & 0.700 & 0.050 & 0.043 & 0.026 & 0.021 & 0.070 & 0.068 & 0.038 & 0.019 & 0.009 \\
\hline $\mathrm{MgO}(\mathrm{Wt} \%)$ & AAS & & 0.57 & 0.16 & 0.35 & 0.54 & 0.68 & 0.69 & 0.60 & 5.66 & 0.42 & 0.47 \\
\hline $\mathrm{Na}_{2} \mathrm{O}(\mathrm{Wt} \%)$ & AES & & 9.60 & 0.74 & 2.06 & 4.99 & 2.24 & 1.90 & 1.44 & 1.59 & 0.69 & 0.74 \\
\hline $\begin{array}{l}\text { Trace Elements } \\
(\mathrm{Wt} \%)\end{array}$ & GFAA & & 3.50 & 0.83 & 0.71 & 1.78 & 1.66 & 0.54 & 0.28 & 0.57 & 0.13 & 0.33 \\
\hline Total $(\mathrm{Wt} \%)$ & & & 93.37 & 17.86 & 56.61 & 90.93 & 101.28 & 79.88 & 77.20 & 76.64 & 78.33 & 104.76 \\
\hline
\end{tabular}

Note: Elemental concentrations have been converted to oxide forms on $\mathrm{SO}_{3}$-free basis. 
Table C-4. Size-Segregated Normalized Major Species Concentrations Ohio Baseline Coal Combustion at 0.5 Residence Second Conditions

\begin{tabular}{|c|c|c|c|c|c|c|c|c|c|c|c|c|}
\hline \multicolumn{2}{|c|}{ Impactor Stage } & 1 & 2 & 3 & 4 & 5 & 6 & 7 & 8 & 9 & 10 & 11 \\
\hline \multicolumn{2}{|c|}{ Cut-off Diameter (microns) } & 0.0324 & 0.0636 & 0.0926 & 0.168 & 0.337 & 0.535 & 0.973 & 1.96 & 3.77 & 7.33 & 15.7 \\
\hline Element & $\begin{array}{l}\text { Analytical } \\
\text { Method }\end{array}$ & & & & & & & & & & & \\
\hline $\begin{array}{l}\text { Total Mass } \\
\text { Conc }\left(\mathrm{g} / \mathrm{Nm}^{3}\right)\end{array}$ & Gravimetric & 0.020 & 0.028 & 0.083 & 0.046 & 0.040 & 0.091 & 0.945 & 1.255 & 4.110 & 3.909 & 0.973 \\
\hline $\mathrm{SiO}_{2}(\mathrm{Wt} \%)$ & AAS & 6.81 & 17.50 & 13.94 & 17.21 & 9.12 & 25.61 & 15.73 & 20.15 & 27.43 & 24.40 & 29.21 \\
\hline $\mathrm{Al}_{2} \mathrm{O}_{3}(\mathrm{Wt} \%)$ & AAS/NAA & 1.58 & 2.10 & 2.23 & 1.15 & 2.07 & 10.38 & 14.32 & 16.69 & 26.83 & 20.64 & 20.13 \\
\hline $\mathrm{Fe}_{2} \mathrm{O}_{3}(\mathrm{Wt} \%)$ & AAS/NAA & 84.51 & 67.58 & 65.44 & 74.36 & 82.96 & 57.32 & 65.52 & 59.20 & 42.47 & 52.80 & 46.29 \\
\hline $\mathrm{CaO}(\mathrm{Wt} \%)$ & AAS/NAA & 0.25 & 0.43 & 0.36 & 0.16 & 0.34 & 0.80 & 0.77 & 0.68 & 0.58 & 0.40 & 0.51 \\
\hline $\mathrm{MgO}(\mathrm{Wt} \%)$ & AAS/NAA & 0.18 & 0.21 & 0.47 & 0.06 & 0.06 & 0.29 & 0.27 & 0.28 & 0.31 & 0.23 & 0.36 \\
\hline $\mathrm{Na}_{2} \mathrm{O}(\mathrm{Wt} \%)$ & AES/NAA & 2.09 & 4.56 & 7.16 & 3.55 & 2.53 & 2.13 & 1.96 & 1.69 & 1.53 & 0.72 & 2.62 \\
\hline $\mathrm{K}_{2} \mathrm{O}(\mathrm{Wt} \%)$ & NAA & 1.95 & 4.46 & 6.24 & 1.56 & 0.87 & 1.49 & 0.03 & 0.07 & 0.15 & 0.28 & 0.12 \\
\hline $\mathrm{TiO}_{2}(\mathrm{Wt} \%)$ & NAA & 0.08 & 0.13 & 0.20 & 0.06 & 0.13 & 0.35 & 0.01 & 0.02 & 0.03 & 0.07 & 0.03 \\
\hline $\mathrm{Cl}(\mathrm{Wt} \%)$ & NAA & 0.11 & 0.13 & 0.23 & 0.12 & 0.13 & 0.23 & 0.00 & 0.00 & 0.01 & 0.02 & 0.03 \\
\hline $\begin{array}{l}\text { Trace Elements } \\
(\mathrm{Wt} \%)\end{array}$ & GFAA/NAA & 2.44 & 2.89 & 3.74 & 1.75 & 1.78 & 1.39 & 1.39 & 1.23 & 0.67 & 0.44 & 0.70 \\
\hline Total $(\mathrm{Wt} \%)$ & & 100.00 & 100.00 & 100.00 & 100.00 & 100.00 & 100.00 & 100.00 & 100.00 & 100.00 & 100.00 & 100.00 \\
\hline
\end{tabular}

Note: Elemental concentrations have been converted to oxide forms on a $\mathrm{SO}_{3}$-free basis. 
Table C-5. Size-Segregated Normalized Major Species Concentrations Ohio Baseline Coal Combustion at 2.2 Residence Second Conditions

\begin{tabular}{|c|c|c|c|c|c|c|c|c|c|c|c|c|}
\hline \multicolumn{2}{|c|}{ Impactor Stage } & 1 & 2 & 3 & 4 & 5 & 6 & 7 & 8 & 9 & 10 & 11 \\
\hline \multicolumn{2}{|c|}{ Cut-off Diameter (microns) } & 0.03 & 0.06 & 0.09 & 0.168 & 0.337 & 0.535 & 0.973 & 1.96 & 3.77 & 7.33 & 15.7 \\
\hline Element & $\begin{array}{c}\text { Analytical } \\
\text { Method }\end{array}$ & & & & & & & & & & & \\
\hline $\begin{array}{l}\text { Total Mass } \\
\text { Conc }\left(\mathrm{g} / \mathrm{Nm}^{3}\right)\end{array}$ & Gravimetric & 0.020 & 0.064 & 0.038 & 0.019 & 0.004 & 0.012 & 0.560 & 2.037 & 1.148 & 2.252 & 0.834 \\
\hline $\mathrm{SiO}_{2}(\mathrm{Wt} \%)$ & AAS & 7.98 & 26.81 & 9.33 & 9.79 & 9.67 & 57.05 & 25.05 & 31.85 & 41.41 & 7.89 & 35.16 \\
\hline $\mathrm{Al}_{2} \mathrm{O}_{3}(\mathrm{Wt} \%)$ & AAS/NAA & 1.39 & 1.87 & 2.58 & 1.61 & 7.25 & 10.20 & 40.83 & 29.10 & 26.44 & 4.51 & 27.96 \\
\hline $\mathrm{Fe}_{2} \mathrm{O}_{3}(\mathrm{Wt} \%)$ & AAS/NAA & 85.56 & 61.75 & 76.58 & 81.91 & 68.33 & 26.36 & 29.13 & 36.04 & 28.55 & 86.84 & 31.81 \\
\hline $\mathrm{CaO}(\mathrm{Wt} \%)$ & AAS/NAA & 0.38 & 0.78 & 1.22 & 0.39 & 1.11 & 1.06 & 0.09 & 0.78 & 0.79 & 0.19 & 1.02 \\
\hline $\mathrm{MgO}(\mathrm{Wt} \%)$ & AAS/NAA & 1.00 & 0.79 & 1.80 & 0.50 & 0.70 & 0.43 & 0.60 & 0.43 & 0.35 & 0.09 & 0.54 \\
\hline $\mathrm{Na}_{2} \mathrm{O}(\mathrm{Wt} \%)$ & AES/NAA & 0.37 & 2.01 & 3.73 & 2.18 & 9.96 & 2.14 & 3.74 & 1.26 & 1.96 & 0.26 & 2.74 \\
\hline $\mathrm{K}_{2} \mathrm{O}(\mathrm{Wt} \%)$ & NAA & 0.92 & 0.70 & 0.71 & 0.39 & ND & 0.89 & 0.01 & 0.04 & 0.12 & 0.02 & 0.12 \\
\hline $\mathrm{TiO}_{2}(\mathrm{Wt} \%)$ & NAA & 0.23 & 0.34 & 0.54 & 0.21 & 0.78 & 0.87 & 0.00 & 0.02 & 0.05 & 0.01 & 0.02 \\
\hline $\mathrm{Cl}(\mathrm{Wt} \%)$ & NAA & 0.17 & 0.05 & 0.08 & 0.10 & 0.15 & 0.05 & 0.00 & 0.01 & 0.02 & 0.00 & 0.02 \\
\hline $\begin{array}{l}\text { Trace Elements } \\
(\mathrm{Wt} \%)\end{array}$ & GFAA/NAA & 2.01 & 4.90 & 3.43 & 2.93 & 2.05 & 0.93 & 0.55 & 0.45 & 0.31 & 0.19 & 0.62 \\
\hline Total $(\mathrm{Wt} \%)$ & & 100.00 & 100.00 & 100.00 & 100.00 & 100.00 & 100.00 & 100.00 & 100.00 & 100.00 & 100.00 & 100.00 \\
\hline
\end{tabular}

Note: Elemental concentrations have been converted to oxide forms on a $\mathrm{SO}_{3}$-free basis. 
Table C-6. Size-Segregated Normalized Major Species Concentrations Ohio Baseline Coal Combustion at Hot-Side ESP Conditions

\begin{tabular}{|c|c|c|c|c|c|c|c|c|c|c|c|c|}
\hline \multicolumn{2}{|c|}{ Impactor Stage } & 1 & 2 & 3 & 4 & 5 & 6 & 7 & 8 & 9 & 10 & 11 \\
\hline \multicolumn{2}{|c|}{ Cut-off Diameter (microns) } & 0.0324 & 0.0636 & 0.0926 & 0.168 & 0.337 & 0.535 & 0.973 & 1.96 & 3.77 & 7.33 & 15.7 \\
\hline Element & $\begin{array}{l}\text { Analytical } \\
\text { Method }\end{array}$ & & & & & & & & & & & \\
\hline $\begin{array}{l}\text { Total Mass } \\
\text { Conc }\left(\mathrm{g} / \mathrm{Nm}^{3}\right)\end{array}$ & Gravimetric & 0.002 & 0.012 & 0.014 & 0.006 & 0.003 & 0.005 & 0.077 & 0.072 & 0.082 & 0.211 & 0.141 \\
\hline $\mathrm{SiO}_{2}(\mathrm{Wt} \%)$ & AAS & & 23.54 & 14.78 & 20.97 & 19.74 & 26.22 & 47.09 & 54.63 & 43.48 & 54.92 & 45.54 \\
\hline $\mathrm{Al}_{2} \mathrm{O}_{3}(\mathrm{Wt} \%)$ & AAS & & 1.31 & 1.20 & 0.25 & 1.47 & 2.30 & 1.47 & 0.87 & 2.42 & 0.09 & 0.10 \\
\hline $\mathrm{Fe}_{2} \mathrm{O}_{3}(\mathrm{Wt} \%)$ & AAS & & 59.77 & 74.04 & 73.20 & 70.71 & 66.94 & 47.43 & 41.41 & 43.84 & 43.39 & 52.88 \\
\hline $\mathrm{CaO}(\mathrm{Wt} \%)$ & AAS & & 0.75 & 0.28 & 0.08 & 0.03 & 0.02 & 0.09 & 0.09 & 0.05 & 0.02 & 0.01 \\
\hline $\mathrm{MgO}(\mathrm{Wt} \%)$ & AAS & & 0.61 & 0.87 & 0.61 & 0.59 & 0.67 & 0.87 & 0.78 & 7.39 & 0.54 & 0.44 \\
\hline $\mathrm{Na}_{2} \mathrm{O}(\mathrm{Wt} \%)$ & AES & & 10.28 & 4.16 & 3.64 & 5.49 & 2.21 & 2.38 & 1.87 & 2.08 & 0.88 & 0.71 \\
\hline $\begin{array}{l}\text { Trace } \\
\text { Elements } \\
(\mathrm{Wt} \%)\end{array}$ & GFAA & & 3.74 & 4.66 & 1.26 & 1.95 & 1.64 & 0.68 & 0.36 & 0.75 & 0.16 & 0.32 \\
\hline Total $(\mathrm{Wt} \%)$ & & & 100.00 & 100.00 & 100.00 & 100.00 & 100.00 & 100.00 & 100.00 & 100.00 & 100.00 & 100.00 \\
\hline
\end{tabular}

Note: Elemental concentrations have been converted to oxide forms on $\mathrm{SO}_{3}$-free basis. 
Table C-7. Size-Segregated Trace Element Concentration Data Ohio Baseline Coal Combustion at 0.5 Residence Second Conditions

\begin{tabular}{|c|c|c|c|c|c|c|c|c|c|c|c|c|}
\hline Impactor & Stage & 1 & 2 & 3 & 4 & 5 & 6 & 7 & 8 & 9 & 10 & 11 \\
\hline \multicolumn{2}{|c|}{ Cut-off Diameter (microns) } & 0.0324 & 0.0636 & 0.0926 & 0.168 & 0.337 & 0.535 & 0.973 & 1.96 & 3.77 & 7.33 & 15.7 \\
\hline Element (ppmw) & $\begin{array}{l}\text { Analytical } \\
\text { Method }\end{array}$ & & & & & & & & & & & \\
\hline As & GFAA/NAA & 1897 & 2088 & 1906 & 1630 & 1914 & 482 & 472 & 481 & 304 & 190 & 284 \\
\hline $\mathrm{Se}$ & GFAA/NAA & 245 & 222 & 243 & 169 & 66 & 52 & 172 & 177 & 127 & 49 & 43 \\
\hline $\mathrm{Cd}$ & GFAA/NAA & 732 & 285 & 666 & 531 & 133 & 91 & 390 & 310 & 234 & 206 & 143 \\
\hline Co & GFAA/NAA & 1195 & 335 & 119 & 363 & 196 & 47 & 36 & 42 & 51 & 18 & 18 \\
\hline $\mathrm{Sb}$ & GFAA/NAA & 1234 & 1441 & 999 & 444 & 235 & 373 & 40 & 40 & 37 & 24 & 35 \\
\hline $\mathrm{Cr}$ & AAS/NAA & 33239 & 7980 & 9438 & 10587 & 20252 & 10056 & 24320 & 24717 & 9919 & 7753 & 9919 \\
\hline Cs & NAA & 30.5 & 15.7 & 18.1 & 10.7 & 9.9 & 15.5 & 1.0 & 1.8 & 1.6 & 5.4 & 1.9 \\
\hline $\mathrm{Sc}$ & NAA & 3.2 & 1.6 & 1.7 & 1.5 & 5.0 & 9.8 & 0.5 & 1.0 & 1.6 & 5.4 & 1.2 \\
\hline V & NAA & 248 & 160 & 218 & 119 & 83 & 94 & 5 & 7 & 11 & 30 & 10 \\
\hline $\mathrm{Mn}$ & NAA & 115 & 24 & 44 & 17 & 39 & 56 & 2 & 5 & 20 & 26 & 11 \\
\hline $\mathrm{Zn}$ & NAA & 832 & 461 & 579 & 456 & 367 & 318 & 1 & 6 & 12 & 87 & 1 \\
\hline $\mathrm{Ga}$ & NAA & 183 & 157 & 181 & 96 & 81 & 81 & 3 & 5 & 5 & 9 & 9 \\
\hline $\mathrm{Rb}$ & NAA & 107 & 67 & 133 & & 29 & 34 & & & & 18 & \\
\hline $\mathrm{Sr}$ & NAA & 152 & 33 & 45 & 19 & 70 & 111 & 11 & 9 & 30 & 58 & 24 \\
\hline
\end{tabular}


Table C-7. Size-Segregated Trace Element Concentration Data Ohio Baseline Coal Combustion at 0.5 Residence Second Conditions (Continued)

\begin{tabular}{|l|l|l|l|l|l|l|l|l|l|l|l|l|}
\hline \multicolumn{1}{|c|}{ Impactor } & \multicolumn{1}{|c|}{ Stage } & 1 & 2 & 3 & 4 & 5 & 6 & 7 & 8 & 9 & 10 & 11 \\
\hline \hline Element (ppmw) & $\begin{array}{c}\text { Analytical } \\
\text { Method }\end{array}$ & & & & & & & & & & \\
& & & & & & & & & & \\
\hline $\mathrm{Mo}$ & NAA & 343 & 197 & 239 & 121 & 55 & 47 & 2 & 4 & 13 & 15 & 8 \\
\hline $\mathrm{In}$ & NAA & 1.086 & 0.700 & 0.877 & 0.503 & 0.241 & 0.253 & 0.024 & 0.013 & 0.019 & & 0.058 \\
\hline $\mathrm{Ba}$ & NAA & 141 & 37 & 61 & 44 & 176 & 158 & 11 & 21 & 35 & 94 & 26 \\
\hline $\mathrm{La}$ & NAA & 4.4 & 1.0 & 1.3 & 2.2 & 10.5 & 21.2 & 1.0 & 2.2 & 3.5 & 12.8 & 2.5 \\
\hline $\mathrm{Ce}$ & NAA & 13.0 & 7.7 & 5.6 & 5.6 & 19.3 & 3.7 & 2.0 & 4.2 & 7.7 & 25.6 & 3.7 \\
\hline $\mathrm{Nd}$ & NAA & & 7.7 & 22.0 & 39.6 & 7.5 & 28.7 & 0.0 & 1.8 & 5.7 & 8.9 & 29.6 \\
\hline $\mathrm{Sm}$ & NAA & 1.4 & 0.6 & 0.7 & 0.6 & 2.1 & 4.0 & 0.2 & 0.4 & 0.2 & 2.6 & 0.5 \\
\hline $\mathrm{Eu}$ & NAA & 2.3 & & 0.2 & & 0.5 & 1.0 & 0.1 & 0.1 & 0.2 & 0.7 & \\
\hline $\mathrm{Yb}$ & NAA & & & 0.9 & & 1.3 & 2.7 & 0.1 & 0.4 & 0.5 & 1.8 & 0.4 \\
\hline $\mathrm{Lu}$ & NAA & & 0.03 & 0.07 & 0.06 & 0.21 & 0.37 & 0.02 & 0.05 & 0.06 & 0.27 & 0.03 \\
\hline $\mathrm{Au}$ & NAA & 0.053 & 0.007 & 0.012 & 0.009 & 0.105 & 0.060 & 0.001 & 0.0005 & 0.0004 & 0.004 & 0.003 \\
\hline $\mathrm{Hg}$ & NAA & 1.8 & 1.0 & 2.2 & 1.8 & 2.2 & 3.7 & 0.2 & 0.2 & 0.2 & 0.5 & 0.3 \\
\hline $\mathrm{Th}$ & NAA & 1.7 & 0.3 & 1.4 & 1.6 & 2.6 & 5.0 & 0.2 & 0.5 & 0.8 & 3.1 & 0.7 \\
\hline $\mathrm{U}$ & NAA & 30.5 & 16.7 & 19.7 & 9.4 & 5.5 & 7.1 & 0.3 & 0.4 & 0.4 & 2.4 & 0.4 \\
\hline $\mathrm{TOTALS} \mathrm{(wt \% )}$ & & 4.08 & 1.35 & 1.49 & 1.47 & 2.38 & 1.21 & 2.55 & 2.58 & 1.08 & 0.86 & 1.06 \\
\hline
\end{tabular}


Table C-8. Size-Segregated Trace Element Concentration Data Ohio Baseline Coal Combustion at 2.2 Residence Second Conditions

\begin{tabular}{|c|c|c|c|c|c|c|c|c|c|c|c|c|}
\hline Impactor & Stage & 1 & 2 & 3 & 4 & 5 & 6 & 7 & 8 & 9 & 10 & 11 \\
\hline \multicolumn{2}{|c|}{ Cut-off Diameter (microns) } & 0.0324 & 0.0636 & 0.0926 & 0.168 & 0.337 & 0.535 & 0.973 & 1.96 & 3.77 & 7.33 & 15.7 \\
\hline $\begin{array}{l}\text { Element } \\
\text { (ppmw) }\end{array}$ & $\begin{array}{l}\text { Analytical } \\
\text { Method }\end{array}$ & & & & & & & & & & & \\
\hline As & GFAA/NAA & 550 & 721 & 554 & 899 & 1969 & 781 & 4251 & 126 & 248 & 229 & 386 \\
\hline $\mathrm{Se}$ & GFAA/NAA & 299 & 178 & 344 & 300 & 238 & 135 & $\mathrm{ND}^{*}$ & ND & 1 & ND & 1 \\
\hline $\mathrm{Cd}$ & GFAA/NAA & 36 & 25 & 24 & 47 & 414 & 602 & 110 & 106 & 102 & 64 & 38 \\
\hline Co & GFAA/NAA & 11 & 9 & 14 & 19 & 100 & 86 & 321 & 57 & 62 & 172 & 44 \\
\hline $\mathrm{Sb}$ & GFAA/NAA & 245 & 1091 & 1379 & 2397 & 195 & 92 & 1 & ND & 1 & 1 & 1 \\
\hline $\mathrm{Cr}$ & AAS/NAA & 8732 & 18739 & 10127 & 20370 & 41337 & 24353 & 29353 & 3575 & 2570 & 9548 & 4852 \\
\hline Cs & NAA & 5.7 & 5.9 & 8.2 & 8.5 & 150.0 & 23.0 & 0.7 & 0.9 & 1.4 & 1.4 & 1.9 \\
\hline $\mathrm{Sc}$ & NAA & 1.7 & 1.4 & 2.1 & 3.1 & 57.1 & 90.5 & 0.5 & 0.5 & 1.3 & 1.2 & 0.5 \\
\hline V & NAA & 86 & 135 & 153 & 148 & 421 & 460 & 6 & 5 & 11 & 9 & 4 \\
\hline $\mathrm{Mn}$ & NAA & 103 & 35 & 54 & 53 & 213 & 214 & 6 & 4 & 10 & 9 & 8 \\
\hline $\mathrm{Zn}$ & NAA & 188 & 57 & 82 & 131 & 571 & 577 & 28 & 18 & 300 & 11 & 178 \\
\hline $\mathrm{Ga}$ & NAA & 61 & 158 & 180 & 127 & 179 & 169 & ND & ND & 3 & ND & ND \\
\hline $\mathrm{Rb}$ & NAA & ND & ND & 15 & 25 & ND & 81 & ND & ND & ND & 4 & ND \\
\hline $\mathrm{Sr}$ & NAA & ND & 30 & 31 & 54 & 421 & 614 & 13 & 5 & 31 & 17 & 12 \\
\hline
\end{tabular}

*ND - below detection limit. 
Table C-8. Size-Segregated Trace Element Concentration Data Ohio Baseline Coal Combustion at 2.2 Residence Second Conditions (Continued)

\begin{tabular}{|c|c|c|c|c|c|c|c|c|c|c|c|c|}
\hline Impactor & Stage & 1 & 2 & 3 & 4 & 5 & 6 & 7 & 8 & 9 & 10 & 11 \\
\hline $\begin{array}{l}\text { Element } \\
\text { (ppmw) }\end{array}$ & $\begin{array}{c}\text { Analytical } \\
\text { Method }\end{array}$ & & & & & & & & & & & \\
\hline Mo & NAA & 309 & 250 & 257 & 232 & 323 & 199 & 2 & 2 & 6 & 5 & 4 \\
\hline In & NAA & 0.37 & 0.17 & 0.28 & 0.25 & 0.98 & 0.75 & 0.02 & 0.02 & 0.02 & ND & ND \\
\hline $\mathrm{Ba}$ & NAA & 81 & 92 & 153 & 158 & 692 & 936 & 14 & 5 & 31 & ND & ND \\
\hline $\mathrm{La}$ & NAA & 1.6 & 1.1 & 1.5 & 2.9 & 80.8 & 141.2 & 0.9 & 1.1 & 2.8 & 2.8 & 1.0 \\
\hline $\mathrm{Ce}$ & NAA & ND & 5 & 8 & 12 & 150 & 276 & 1 & 2 & 6 & 6 & 1 \\
\hline $\mathrm{Nd}$ & NAA & 38 & 14 & 16 & 18 & 201 & 107 & 3 & 4 & 3 & 4 & 9 \\
\hline $\mathrm{Sm}$ & NAA & 0.3 & 0.4 & 0.5 & 0.9 & 5.4 & 30.7 & 0.2 & 0.2 & 0.6 & 0.6 & 0.2 \\
\hline $\mathrm{Eu}$ & NAA & ND & 0.3 & 0.5 & 0.9 & 5.4 & 6.8 & 0.1 & 0.1 & ND & 0.2 & 0.2 \\
\hline $\mathrm{Yb}$ & NAA & ND & ND & ND & ND & 11.0 & 19.9 & 0.2 & 0.2 & 0.5 & 0.4 & 0.3 \\
\hline $\mathrm{Lu}$ & NAA & ND & 0.11 & 0.14 & 0.14 & 2.37 & 4.30 & 0.02 & 0.02 & 0.08 & 0.06 & ND \\
\hline $\mathrm{Au}$ & NAA & 0.026 & 0.013 & 0.016 & 0.017 & 0.054 & 0.023 & 0.002 & 0.002 & 0.003 & 0.025 & 0.002 \\
\hline $\mathrm{Hg}$ & NAA & 0.8 & ND & 0.5 & 1.0 & 8.0 & 3.0 & 0.3 & 0.3 & 0.5 & 0.3 & 0.5 \\
\hline Th & NAA & ND & 0.6 & 1.1 & 1.3 & 27.0 & 39.8 & 0.2 & 0.2 & 0.7 & 0.5 & 0.4 \\
\hline $\mathrm{U}$ & NAA & 2.74 & 5.59 & 6.56 & 3.80 & 31.73 & 75.19 & 0.10 & 0.05 & 0.58 & ND & 0.14 \\
\hline $\begin{array}{l}\text { TOTALS } \\
(\mathrm{wt} \%)\end{array}$ & & 1.08 & 2.16 & 1.34 & 2.50 & 4.78 & 3.01 & 3.41 & 0.39 & 0.34 & 1.01 & 0.55 \\
\hline
\end{tabular}


Table C-9. Size-Segregated Trace Element Concentration Data Ohio Baseline Coal Combustion at Hot-Side ESP Conditions

\begin{tabular}{|l|l|l|l|l|l|l|l|l|l|l|l|l|}
\hline \multicolumn{1}{|c|}{ Impactor } & \multicolumn{1}{c|}{ Stage } & 1 & 2 & 3 & 4 & 5 & 6 & 7 & 8 & 9 & 10 & 11 \\
\hline \hline Cut-off Diameter (microns) & 0.0324 & 0.0636 & 0.0926 & 0.168 & 0.337 & 0.535 & 0.973 & 1.96 & 3.77 & 7.33 & 15.7 \\
\hline \multicolumn{1}{|c|}{$\begin{array}{c}\text { Enalytical } \\
\text { Method }\end{array}$} & & & & & & & & & & & \\
\hline $\mathrm{As}$ & GFAA & & 8605 & 2235 & 1282 & 1109 & 933 & 755 & 660 & 351 & 217 & 708 \\
\hline $\mathrm{Se}$ & GFAA & & 3657 & 260 & 205 & 103 & 29 & 10 & 11 & 12 & 7 & 4 \\
\hline $\mathrm{Cd}$ & GFAA & & 5005 & 357 & 304 & 184 & 153 & 498 & 488 & 272 & 133 & 66 \\
\hline $\mathrm{Co}$ & GFAA & & 55 & 12 & 30 & 40 & 125 & 72 & 59 & 32 & 27 & 29 \\
\hline $\mathrm{Sb}$ & GFAA & & 504 & 103 & 103 & 65 & 78 & 81 & 72 & 128 & 9 & 64 \\
\hline $\mathrm{Cr}$ & AAS & & 17143 & 5363 & 5217 & 16271 & 15319 & 3983 & 1509 & 4948 & 882 & 2443 \\
\hline $\mathrm{TOTALs} \mathrm{(wt \% )}$ & & & 3.50 & 0.83 & 0.71 & 1.78 & 1.66 & 0.54 & 0.28 & 0.57 & 0.13 & 0.33 \\
\hline
\end{tabular}




\section{APPENDIX D}

Ash Composition from Baseline Combustion Experiments at the University of Arizona for Wyodak Coal 
Table D-1. Preliminary Size-Segregated Major Species Concentration Data Wyodak Baseline Coal Combustion at 1.4 Residence Second Conditions

\begin{tabular}{|c|c|c|c|c|c|c|c|c|c|c|c|c|}
\hline Impactor & Stage & 1 & 2 & 3 & 4 & 5 & 6 & 7 & 8 & 9 & 10 & 11 \\
\hline \multicolumn{13}{|c|}{ Cut-off Diameter (microns) } \\
\hline Element & $\begin{array}{c}\text { Analytical } \\
\text { Method }\end{array}$ & & & & & & & & & & & \\
\hline $\begin{array}{l}\text { Total Mass } \\
\text { Conc }\left(\mathrm{g} / \mathrm{Nm}^{3}\right)\end{array}$ & Gravimetric & 0.011 & 0.013 & 0.019 & 0.026 & 0.018 & 0.028 & 0.053 & 0.097 & 0.098 & 0.172 & 0.046 \\
\hline $\mathrm{SiO}_{2}(\mathrm{Wt} \%)$ & AAS & 4.03 & 0.61 & 0.79 & ND & 0.89 & 7.48 & 41.78 & 78.80 & 93.17 & 269.72 & 19.33 \\
\hline $\mathrm{Al}_{2} \mathrm{O}_{3}(\mathrm{Wt} \%)$ & AAS & $\mathrm{TBD}^{*}$ & TBD & TBD & TBD & TBD & TBD & $\mathrm{TBD}$ & TBD & TBD & TBD & TBD \\
\hline $\mathrm{Fe}_{2} \mathrm{O}_{3}(\mathrm{Wt} \%)$ & AAS & 1.51 & $\mathrm{ND}^{\dagger}$ & ND & 1.53 & 2.70 & 9.04 & 28.70 & 45.55 & 42.87 & 97.58 & 20.59 \\
\hline $\mathrm{CaO}(\mathrm{Wt} \%)$ & AAS & 2.75 & 0.48 & 1.05 & 1.11 & 2.82 & 12.06 & 34.00 & 143.76 & 61.67 & 501.63 & 69.62 \\
\hline $\mathrm{MgO}(\mathrm{Wt} \%)$ & AAS & 0.23 & 0.04 & 0.09 & 0.11 & 0.27 & 2.07 & 6.90 & 9.13 & 9.37 & 16.52 & 5.93 \\
\hline $\mathrm{Na}_{2} \mathrm{O}(\mathrm{Wt} \%)$ & AES & 1.07 & 0.29 & 0.34 & 0.33 & 0.64 & 2.93 & 6.81 & 18.83 & 23.20 & 10.12 & 3.76 \\
\hline $\begin{array}{l}\text { Trace Elements } \\
(\mathrm{Wt} \%)\end{array}$ & GFAA & 0.20 & 0.04 & 0.09 & 0.12 & 0.22 & 0.61 & 1.87 & 3.07 & 3.11 & 3.52 & 1.89 \\
\hline Total (Wt\%) & & 9.79 & 1.47 & 2.36 & 3.19 & 7.54 & 34.19 & 120.06 & 299.13 & 233.38 & 899.10 & 121.13 \\
\hline
\end{tabular}

Note: Elemental concentrations have been converted to oxide forms on a $\mathrm{SO}_{3}$-free basis.

"TBD - Aluminum analyses are not yet completed; updated silica analyses are also still in progress.

ND - Below detection limit. 
Table D-2. Preliminary Size-Segregated Major Species Concentration Data Wyodak Baseline Coal Combustion at 6.6 Residence Second Conditions

\begin{tabular}{|c|c|c|c|c|c|c|c|c|c|c|c|c|}
\hline Impactor & Stage & 1 & 2 & 3 & 4 & 5 & 6 & 7 & 8 & 9 & 10 & 11 \\
\hline \multicolumn{2}{|c|}{ Cut-off Diameter (microns) } & 0.0324 & 0.0636 & 0.0926 & 0.168 & 0.337 & 0.535 & 0.973 & 1.96 & 3.77 & 7.33 & 15.7 \\
\hline Element & $\begin{array}{c}\text { Analytical } \\
\text { Method }\end{array}$ & & & & & & & & & & & \\
\hline $\begin{array}{l}\text { Total Mass } \\
\text { Conc }\left(\mathrm{g} / \mathrm{Nm}^{3}\right)\end{array}$ & Gravimetric & 0.002 & 0.003 & 0.006 & 0.006 & 0.004 & 0.012 & 0.023 & 0.046 & 0.044 & 0.046 & 0.017 \\
\hline $\mathrm{SiO}_{2}(\mathrm{Wt} \%)$ & AAS & 4.02 & 24.51 & 13.83 & 6.21 & 32.29 & 11.66 & 12.91 & 10.97 & 29.20 & 24.09 & 11.77 \\
\hline $\mathrm{Al}_{2} \mathrm{O}_{3}(\mathrm{Wt} \%)$ & AAS & $\mathrm{TBD}^{*}$ & TBD & TBD & TBD & TBD & TBD & TBD & TBD & TBD & TBD & TBD \\
\hline $\mathrm{Fe}_{2} \mathrm{O}_{3}(\mathrm{Wt} \%)$ & AAS & 83.55 & 56.68 & 6.71 & 8.96 & 23.71 & 14.10 & 15.71 & 11.23 & 12.42 & 9.56 & 6.99 \\
\hline $\mathrm{CaO}(\mathrm{Wt} \%)$ & AAS & 72.96 & 25.42 & 16.51 & 14.56 & 28.86 & 21.48 & 27.32 & 20.85 & 15.12 & 16.84 & 12.78 \\
\hline $\mathrm{MgO}(\mathrm{Wt} \%)$ & AAS & 6.68 & 3.40 & 1.39 & 1.55 & 3.55 & 3.27 & 3.77 & 2.44 & 2.82 & 2.04 & 1.68 \\
\hline $\mathrm{Na}_{2} \mathrm{O}(\mathrm{Wt} \%)$ & AES & 31.96 & 9.06 & 8.94 & 2.56 & 3.81 & 2.06 & 3.51 & 3.90 & 3.40 & 1.20 & 2.37 \\
\hline $\begin{array}{l}\text { Trace Elements } \\
(\mathrm{Wt} \%)\end{array}$ & GFAA & 3.01 & 2.33 & 0.64 & 0.62 & 0.87 & 0.51 & 0.88 & 0.61 & 0.88 & 0.39 & 0.25 \\
\hline Total (Wt\%) & & 202.18 & 121.41 & 48.03 & 34.46 & 93.08 & 53.07 & 64.09 & 50.01 & 63.84 & 54.11 & 35.84 \\
\hline
\end{tabular}

Note: Elemental concentrations have been converted to oxide forms on a $\mathrm{SO}_{3}$-free basis.

"TBD - Aluminum analyses are not yet completed; updated silica analyses are also still in progress. 
Table D-3. Preliminary Size-Segregated Major Species Concentration Data Wyodak Baseline Coal Combustion at Hot-Side ESP Conditions

\begin{tabular}{|c|c|c|c|c|c|c|c|c|c|c|c|c|}
\hline Impactor & Stage & 1 & 2 & 3 & 4 & 5 & 6 & 7 & 8 & 9 & 10 & 11 \\
\hline \multicolumn{2}{|c|}{ Cut-off Diameter (microns) } & 0.0324 & 0.0636 & 0.0926 & 0.168 & 0.337 & 0.535 & 0.973 & 1.96 & 3.77 & 7.33 & 15.7 \\
\hline Element & $\begin{array}{c}\text { Analytical } \\
\text { Method }\end{array}$ & & & & & & & & & & & \\
\hline $\begin{array}{l}\text { Total Mass } \\
\text { Conc. }\left(\mathrm{g} / \mathrm{Nm}^{3}\right)\end{array}$ & Gravimetric & 0.003 & 0.005 & 0.010 & 0.009 & 0.009 & 0.022 & 0.061 & 0.132 & 0.221 & 0.447 & 0.049 \\
\hline $\mathrm{SiO} 2(\mathrm{Wt} \%)$ & AAS & $\mathrm{ND}^{*}$ & ND & ND & 9.81 & 18.01 & 9.92 & 18.59 & 30.62 & 21.67 & 34.26 & 28.05 \\
\hline $\mathrm{Al}_{2} \mathrm{O}_{3}(\mathrm{Wt} \%)$ & AAS & $\mathrm{TBD}^{\dagger}$ & TBD & TBD & TBD & TBD & TBD & TBD & TBD & TBD & TBD & TBD \\
\hline $\mathrm{Fe}_{2} \mathrm{O}_{3}(\mathrm{Wt} \%)$ & AAS & 13.02 & 6.29 & 4.04 & 23.54 & 10.72 & 13.89 & 15.52 & 12.99 & 6.54 & 8.05 & 10.38 \\
\hline $\mathrm{CaO}(\mathrm{Wt} \%)$ & AAS & 12.67 & 12.38 & 18.32 & 7.33 & 8.05 & 15.59 & 10.29 & 4.46 & 10.10 & 2.46 & 14.90 \\
\hline $\mathrm{MgO}(\mathrm{Wt} \%)$ & AAS & 1.07 & 0.94 & 1.57 & 1.42 & 1.90 & 3.80 & 3.55 & 4.67 & 1.74 & 0.47 & 2.20 \\
\hline $\mathrm{Na}_{2} \mathrm{O}(\mathrm{Wt} \%)$ & AES & 13.95 & 4.58 & 3.91 & 3.00 & 1.83 & 2.46 & 2.84 & 4.15 & 1.34 & 1.03 & 1.55 \\
\hline $\begin{array}{l}\text { Trace Elements } \\
(\mathrm{Wt} \%)\end{array}$ & GFAA & 1.28 & 1.72 & 0.74 & 0.52 & 0.59 & 0.85 & 1.13 & 1.18 & 0.37 & 0.16 & 0.45 \\
\hline Total (Wt\%) & & 41.99 & 25.91 & 28.59 & 45.61 & 41.10 & 46.50 & 51.92 & 58.07 & 41.76 & 46.43 & 57.54 \\
\hline
\end{tabular}

Note: Elemental concentrations have been converted to oxide forms on a $\mathrm{SO}_{3}$-free basis.

"D - Below detection limit.

${ }^{\dagger} \mathrm{BD}$ - Aluminum analyses are not yet completed; updated silica analyses are also still in progress. 
Table D-4. Preliminary Size-Segregated Trace Element Concentration Data Wyodak Baseline Coal Combustion at 1.4 Res. Sec. Conditions

\begin{tabular}{|c|c|c|c|c|c|c|c|c|c|c|c|c|}
\hline Impactor & Stage & 1 & 2 & 3 & 4 & 5 & 6 & 7 & 8 & 9 & 10 & 11 \\
\hline \multicolumn{2}{|c|}{ Cut-off Diameter (microns) } & 0.0324 & 0.0636 & 0.0926 & 0.168 & 0.337 & 0.535 & 0.973 & 1.96 & 3.77 & 7.33 & 15.7 \\
\hline Element & $\begin{array}{c}\text { Analytical } \\
\text { Method }\end{array}$ & & & & & & & & & & & \\
\hline As & GFAA & 46 & 9 & 17 & 13 & 24 & 62 & 159 & 207 & 239 & 283 & 221 \\
\hline $\mathrm{Se}$ & GFAA & 15.3 & 1.9 & 6.8 & 3.8 & 5.2 & 37 & 102 & 125 & 107 & 134 & 61 \\
\hline $\mathrm{Cd}$ & GFAA & 211 & 79 & 224 & 527 & 504 & 3653 & 13816 & 21160 & 25352 & 24759 & 9860 \\
\hline Co & GFAA & $\mathrm{ND}^{*}$ & ND & ND & ND & ND & 63 & 282 & 541 & 471 & 1044 & 178 \\
\hline $\mathrm{Sb}$ & GFAA & 11 & 6 & 5 & 5 & 14 & 326 & 58 & 42 & 56 & 71 & 84 \\
\hline $\mathrm{Cr}$ & GFAA & 1754 & 309 & 636 & 607 & 1666 & 1947 & 4274 & 8586 & 4849 & 8957 & 8494 \\
\hline TOTALS (wt\%) & & 0.20 & 0.04 & 0.09 & 0.12 & 0.22 & 0.61 & 1.87 & 3.07 & 3.11 & 3.52 & 1.89 \\
\hline
\end{tabular}

*ND - Below detection limit. 
Table D-5. Prelminary Size-Segregated Trace Element Concentration Data Wyodak Baseline Coal Combustion at 6.6 Res. Sec. Conditions

\begin{tabular}{|c|c|c|c|c|c|c|c|c|c|c|c|c|}
\hline Impactor & Stage & 1 & 2 & 3 & 4 & 5 & 6 & 7 & 8 & 9 & 10 & 11 \\
\hline \multicolumn{2}{|c|}{ Cut-off Diameter (microns) } & 0.0324 & 0.0636 & 0.0926 & 0.168 & 0.337 & 0.535 & 0.973 & 1.96 & 3.77 & 7.33 & 15.7 \\
\hline Element & $\begin{array}{c}\text { Analytical } \\
\text { Method }\end{array}$ & & & & & & & & & & & \\
\hline As & GFAA & 616 & 332 & 111 & 184 & 207 & 169 & 108 & 87 & 66 & 29 & 52 \\
\hline $\mathrm{Se}$ & GFAA & $\mathrm{ND}^{*}$ & ND & 38.9 & 48.1 & ND & 23 & 23 & 12 & 8 & 5 & ND \\
\hline $\mathrm{Cd}$ & GFAA & 2688 & 2906 & 2683 & 1045 & 1956 & 2265 & 6645 & 4773 & 6304 & 2792 & 1403 \\
\hline Co & GFAA & ND & ND & ND & ND & 71 & 110 & 254 & 106 & 102 & 45 & 48 \\
\hline $\mathrm{Sb}$ & GFAA & 29 & 32 & 14 & 10 & 36 & 9 & 8 & 4 & 3 & 7 & 16 \\
\hline $\mathrm{Cr}$ & GFAA & 26770 & 19998 & 3536 & 4886 & 6422 & 2545 & 1730 & 1118 & 2352 & 1004 & 967 \\
\hline TOTALS (wt $\%)$ & & 3.01 & 2.33 & 0.64 & 0.62 & 0.87 & 0.51 & 0.88 & 0.61 & 0.88 & 0.39 & 0.25 \\
\hline
\end{tabular}

*ND - Below detection limit. 
Table D-6. Prelminary Size-Segregated Trace Element Concentration Data Wyodak Baseline Coal Combustion at Hot-side ESP Conditions

\begin{tabular}{|c|c|c|c|c|c|c|c|c|c|c|c|c|}
\hline Impactor & Stage & 1 & 2 & 3 & 4 & 5 & 6 & 7 & 8 & 9 & 10 & 11 \\
\hline \multicolumn{2}{|c|}{ Cut-off Diameter (microns) } & 0.0324 & 0.0636 & 0.0926 & 0.168 & 0.337 & 0.535 & 0.973 & 1.96 & 3.77 & 7.33 & 15.7 \\
\hline Element & $\begin{array}{c}\text { Analytica } \\
\text { Method }\end{array}$ & & & & & & & & & & & \\
\hline As & GFAA & 185 & 99 & 74 & 61 & 95 & 67 & 73 & 72 & 34 & 10 & 29 \\
\hline $\mathrm{Se}$ & GFAA & $\mathrm{ND}^{*}$ & ND & 78 & 48 & 81 & 46 & 46 & 39 & 15 & 8 & 18 \\
\hline $\mathrm{Cd}$ & GFAA & 768 & 601 & 750 & 2535 & 2242 & 5308 & 9449 & 10202 & 3042 & 1279 & 3066 \\
\hline Co & GFAA & ND & ND & 38 & 41 & 56 & 96 & 142 & 195 & 132 & 60 & 74 \\
\hline $\mathrm{Sb}$ & GFAA & 180 & 71 & 29 & 13 & 12 & 128 & 19 & 24 & 3 & 1 & 9 \\
\hline $\mathrm{Cr}$ & GFAA & 11634 & 4024 & 6427 & 2456 & 3404 & 2898 & 1533 & 1247 & 516 & 234 & 1274 \\
\hline TOTALS (wt\%) & & 1.28 & 1.72 & 0.74 & 0.52 & 0.59 & 0.85 & 1.13 & 1.18 & 0.37 & 0.16 & 0.45 \\
\hline
\end{tabular}

*ND - Below detection limit. 


\section{APPENDIX E}

Ash Composition from Baseline Combustion Experiments at the

University of Arizona for Illinois No.6 Coal 
Table E-1. Preliminary Size-Segregated Major Species Concentration Data Illinois \#6 Baseline Coal Combustion at Hot-Side ESP Conditions

\begin{tabular}{|l|l|l|l|l|l|l|l|l|l|l|l|l|}
\hline \multicolumn{1}{|c|}{ Impactor } & \multicolumn{1}{c|}{ Stage } & 1 & 2 & 3 & 4 & 5 & 6 & 7 & 8 & 9 & 10 & 11 \\
\hline \hline Cut-off Diameter (microns) & 0.0324 & 0.0636 & 0.0926 & 0.168 & 0.337 & 0.535 & 0.973 & 1.96 & 3.77 & 7.33 & 15.7 \\
\hline \multicolumn{1}{|c|}{ Element } & $\begin{array}{c}\text { Analytical } \\
\text { Method }\end{array}$ & & & & & & & & & & \\
\hline $\begin{array}{l}\text { Total Mass } \\
\mathrm{Conc} .\left(\mathrm{g} / \mathrm{Nm}^{3}\right)\end{array}$ & Gravimetric & 0.016 & 0.016 & 0.025 & 0.023 & 0.023 & 0.046 & 0.123 & 0.247 & 0.336 & 0.679 & 0.130 \\
\hline $\mathrm{SiO}_{2}(\mathrm{Wt} \%)$ & AAS & $\mathrm{ND}^{*}$ & 10.31 & 41.89 & 156.12 & 393.63 & 147.52 & 52.68 & 144.55 & 221.58 & 313.92 & 203.82 \\
\hline $\mathrm{Al}_{2} \mathrm{O}_{3}(\mathrm{Wt} \%)$ & AAS & $\mathrm{TBD}^{\dagger}$ & $\mathrm{TBD}$ & $\mathrm{TBD}$ & $\mathrm{TBD}$ & $\mathrm{TBD}$ & $\mathrm{TBD}$ & $\mathrm{TBD}$ & $\mathrm{TBD}$ & $\mathrm{TBD}$ & $\mathrm{TBD}$ & $\mathrm{TBD}$ \\
\hline $\mathrm{Fe}_{2} \mathrm{O}_{3}(\mathrm{Wt} \%)$ & AAS & 112.70 & 167.32 & 182.25 & 193.70 & 595.79 & 429.69 & 479.30 & 299.09 & 202.58 & 172.46 & 310.97 \\
\hline $\mathrm{CaO}(\mathrm{Wt} \%)$ & AAS & 136.06 & 98.10 & 70.72 & 83.45 & 217.05 & 75.23 & 28.29 & 37.04 & 34.82 & 37.52 & 33.99 \\
\hline $\mathrm{MgO}(\mathrm{Wt} \%)$ & AAS & 12.76 & 8.42 & 21.10 & 8.92 & 15.56 & 7.20 & 5.47 & 5.55 & 7.04 & 9.14 & 6.85 \\
\hline $\mathrm{Na}{ }_{2} \mathrm{O}(\mathrm{Wt} \%)$ & AES & 124.52 & 80.80 & 81.01 & 49.11 & 66.48 & 20.95 & 13.98 & 7.82 & 9.10 & 6.04 & 12.98 \\
\hline $\begin{array}{l}\mathrm{Trace} \text { Elements } \\
(\mathrm{Wt} \%)\end{array}$ & GFAA & 1.14 & 1.44 & 1.30 & 1.06 & 4.89 & 2.13 & 2.73 & 1.30 & 0.90 & 0.50 & 0.64 \\
\hline $\mathrm{Total}(\mathrm{Wt} \%)$ & & 387.18 & 366.38 & 398.26 & 492.35 & 1293.42 & 682.73 & 582.47 & 495.36 & 476.02 & 539.58 & 569.25 \\
\hline
\end{tabular}

Note: Elemental concentrations have been converted to oxide forms on a $\mathrm{SO}_{3}$-free basis.

ND - Below detection limit.

†TBD - Aluminum analysis is not yet complete; silicon results also to be updated in the future. 
Table E-2. Prelminary Size-Segregated Trace Element Concentration Data Illinois \#6 Baseline Coal Combustion at Hot-Side ESP Conditions

\begin{tabular}{|c|c|c|c|c|c|c|c|c|c|c|c|c|}
\hline Impactor & Stage & 1 & 2 & 3 & 4 & 5 & 6 & 7 & 8 & 9 & 10 & 11 \\
\hline \multicolumn{2}{|c|}{ Cut-off Diameter (microns) } & 0.0324 & 0.0636 & 0.0926 & 0.168 & 0.337 & 0.535 & 0.973 & 1.96 & 3.77 & 7.33 & 15.7 \\
\hline Element & $\begin{array}{c}\text { Analytical } \\
\text { Method }\end{array}$ & & & & & & & & & & & \\
\hline As & GFAA & 269.50 & 229.77 & 229.53 & 129.06 & 226.90 & 121.33 & 126.76 & 87.93 & 52.81 & 29.25 & 37.90 \\
\hline $\mathrm{Se}$ & GFAA & 258.00 & 113.34 & 172.42 & 72.03 & 99.11 & 41.89 & 32.57 & 8.05 & 6.21 & 5.87 & 14.74 \\
\hline $\mathrm{Cd}$ & GFAA & 1970 & 3160 & 7225 & 7185 & 42243 & 18989 & 26331 & 12431 & 8583 & 4805 & 5789 \\
\hline Co & GFAA & 85.22 & 139.06 & 60.24 & 36.34 & 123.69 & 57.47 & 35.94 & 33.24 & 32.68 & 39.18 & 41.29 \\
\hline $\mathrm{Sb}$ & GFAA & 129.94 & 80.67 & 62.13 & 51.04 & 109.16 & 32.74 & 15.18 & 11.29 & 41.53 & 8.14 & 20.36 \\
\hline $\mathrm{Cr}$ & GFAA & 8676.69 & 10626.44 & 5213.59 & 3095.39 & 6124.20 & 2070.64 & 795.62 & 434.66 & 282.27 & 159.77 & 543.90 \\
\hline TOTALS (wt\%) & & 1.14 & 1.44 & 1.30 & 1.06 & 4.89 & 2.13 & 2.73 & 1.30 & 0.90 & 0.50 & 0.64 \\
\hline
\end{tabular}

